TERTIARY FORMATIONS AND ASSOCIATED MESOZOIC ROCKS

IN THE ALASKA PENINSULA AREA, ALASKA,

AND THEIR PETROLEUM-RESERVOIR AND SOURCE-ROCK POTENTIAL

BY

W. M. LYLE and J. A. MOREHOUSE

Alaska Division of Geological and Geophysical Surveys,

and

IRVEN F. PALMER, JR., and I. G. BOLM,

U.S. Geological Survey

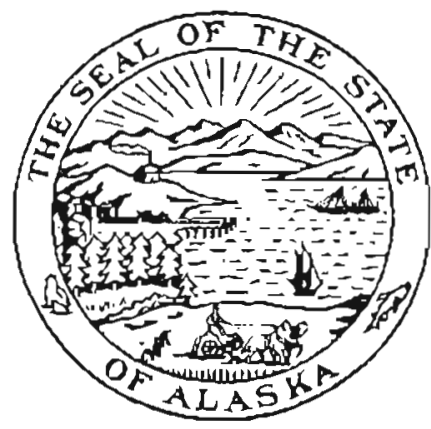

Published by

DIVISION OF GEOLOGICAL \& GEOPHYSICAL SURVEYS

Anchorage, Alaska

1979 


\author{
STATE OF ALASKA \\ Jay S. Hammond, Governor \\ DEPARTMENT OF NATURAL RESOURCES \\ Robert E. LeResche, Commissioner \\ DIVISION OF GEOLOGICAL \& GEOPHYSICAL SURVEYS \\ Ross G. Schaff
}

For sale by Alaska Division of Geological and Geophysical Surveys, P.O. Box 80007, College, 99708; 3327 Fairbanks Sı, Anchorage, 99503;P.O. Box 7438, Ketchikan 99901; and Pouch M, Juneau, 99811. 


\section{CONTENTS}

\section{Abstract}

Introduction

Personnel and logistics

Field methods

Measurement of stratigraphic sections

Lithologic descriptions

Sampling

Naknek Formation

Chignik Formation

Hoodoo Formation

Tolstoi Formation

Stepovak Formation

Bear Lakc Formation

Tachilni Formation

Measured stratigraphic sections

Black Lake

Milky River

Southeast Bcar Lako

Heren I and II

Waterfall Point

Lefthand Bay-Balboa Bay.

Beaver Bay and Beaver Bay Eas

Aliaksin Peninsula

White Bluff

East Morzhovoi Bay

Wesc Morzhovoi Bay

Reservoir characteristics

Reservoir gcometry and size

Reservoir porosities and permeabilities

Reservoir structure and spatial relationship

Basin maturity

Hydrocarban source rocks

Structural geology

Petrography

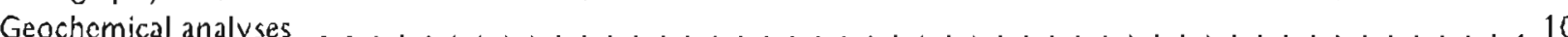

Paleontological determinations . . . . . . . . . . . . . . . . . . . .......10

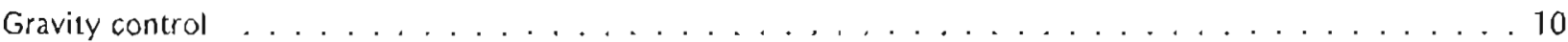

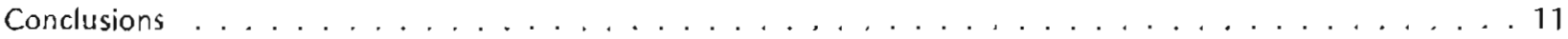

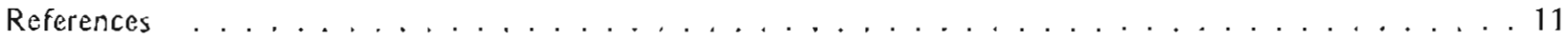




\section{ILLUSTRATIONS}

Index maps of $2^{\circ}$ quadrangle maps showing sampling and stratigraphic section localitics:

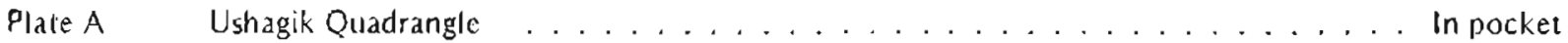

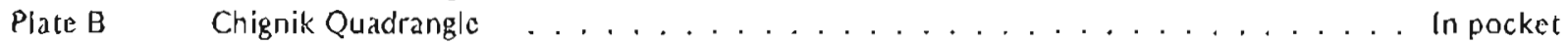

Plate C Cold Bay Quadrangle ....................... In pocket

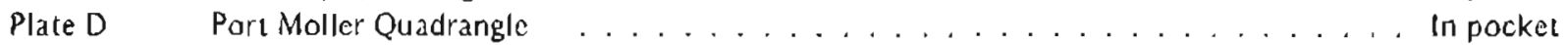

Plate E Stcpovak Quadrangle ......................... In pocket

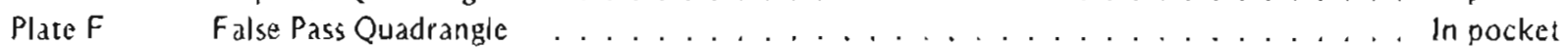

Stratigraphic Sections:

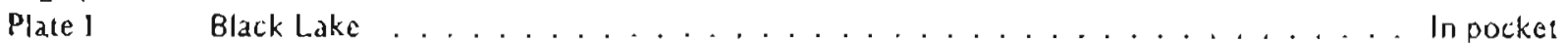

Plate Il Milky River ............................. In pocket

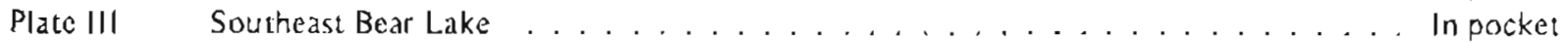

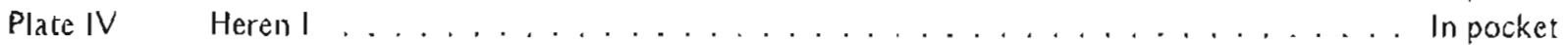

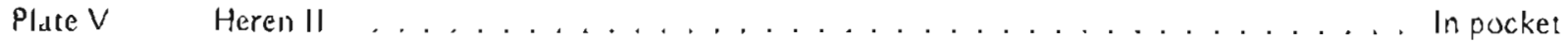

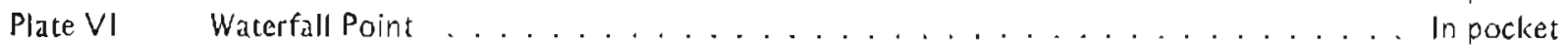

Plate VII Lefthand Bay-Balboa Bay . . . . . . . . . . . . . . . . . . In pocket

Plate VIII Beaver 8ay . . . . . . . . . . . . . . . . . . . . . . . In pockct

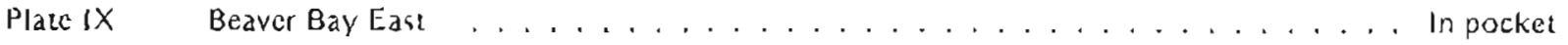

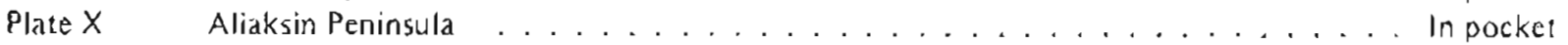

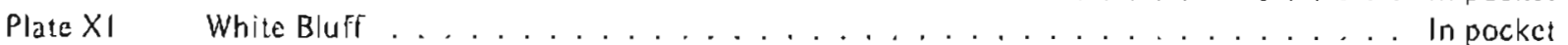

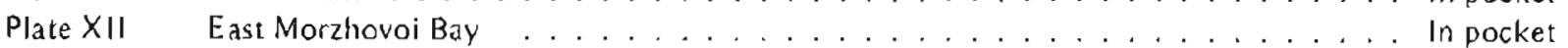

Plate XIII West Morzhovoi Bay ........................ In pocket

Figure 1-Map showing 1977 State-Federal Alaska Peninsula

Page

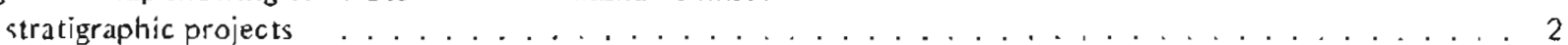

Figures 2 through 24-Photographs of representative outcrops at

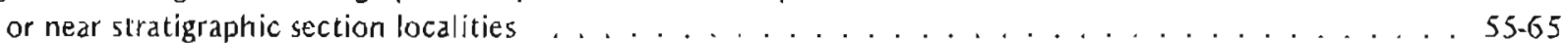

\section{TABLES}

Tables $1 \mathrm{~A}$ and $18-$-Cross reference

Table 1 A - Map numbers to sample or station numbers . . . . . . . . . . . . . . . . . 12

Table 1B - Sample or station numbers to map numbers . . . . . . . . . . . . . . . . . . 25

Table IC - Gravity station numbers to map numbers ... . . . . . . . . . . . . . . . 34

Table 10 - Triangle numbers lo map numbers $\ldots \ldots \ldots . \ldots$

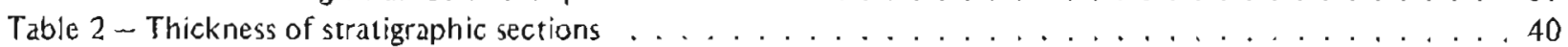

Table 3 - Porosity and permeability analyses . . . . . . . . . . . . . . . . . . . . . . . . 41

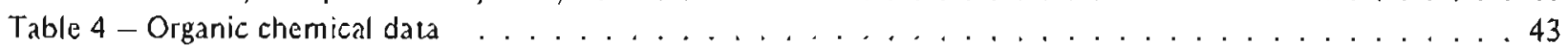

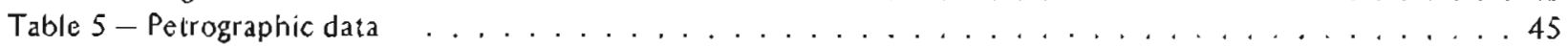

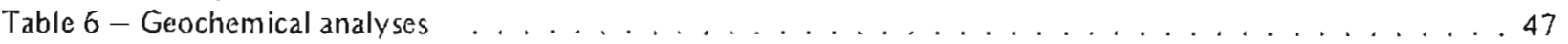

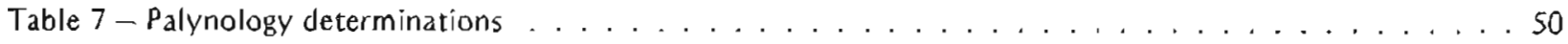

Table 8 - Macropaleontology determinations . . . . . . . . . . . . . . . . . . . . . . . . . . . . . . 


\title{
TERTIARY FORMATIONS AND ASSOCIATED MESOZOIC ROCKS IN THE ALASKA PENINSULA AREA, ALASKA, AND THEIR PETROLEUM-RESERVOIR AND SOURCE-ROCK POTENTIAL
}

\author{
By \\ W. M. Lyle and J. A. Morehouse,' \\ and Irven F. Palmer, J r., and ). G. Bolm ${ }^{2}$
}

\section{ABSTR ACT}

Fourteen serallgraphic sections lolaling over 16,000 feet $(5,000 \mathrm{~m})$ were measured in a 1977 joint statc-Federal project to desernine the petroleum-reservoir and source-rock potential of the Alaska Peninsula. The percentage of polential Tertiary reservolr sandstone to the total siraligraphic section measured ranges from less than onc to 100 percent, with an average of 63 percent. Sandsiones range fiom less than 3 feet to over 100 feet in thickness. Porosities and germedbilities arc low in most areas as a result of pervasive pore-filling mineralizalion. Laboratory analyses indicate that potential reservoir rocks have been prescrv. ed In certain instances; howcver, thelr of fshore extension is unknown.

Hydrocarbon $C_{15}$. cxiraces range trom 37 ppm (paris per million) $102,981 \mathrm{ppm}$; llic average for 69 samples is $362 \mathrm{ppm}$, whlch is above (he generally accepted level for petroleum source rack. Organic carbon ranges from less than 0.2 (6) more than 8.0 percent. Thermal alleration index (TAI), based on kerogen assessment, ranges from 1+ to 3+; most samples have a TAl of 2 . to 2t. Maior constifuents are herbaceous-spore debris with lesser dmounis of woody and amorphous-sapropel grains. Dry gas is the most probable hydrocarbon to form in these source rocks.

\section{INTRODUCTION}

A stratigraphic field project was conducted on the Alaska Peninsula during a 24-day pcriod in June and July of 1977 by the U.S. Geological Survey (USGS) and the State of Alaska, Division of Geological and Geophysical Surveys (DGGS) (fig. 1). The projecr was similar in scope to previous cooperative State-Federal rield projects completed in 1975 in the Gulf of Alaska Tertiary province and in 1976 in the uplands near lower Cook Inlet and Kodiak Island.

Both State and Federal agencies are responsible for the cvaluation of petroleum potential of all submerged lands under their jurisdictions. Collaboration of State and Federal geologists on these projects results in uniformity in the collecting and processing of geological

1 Alaska Division of Geological and Geophysical Surveys

2 U.S. Geological Survey. data and eliminates (or greatly reduces) duplication of cffort.

Data are extrapolated into the adjacent submerged areas and serve ds input to evaluation programs being conducted in all areas that have any futurc offshore lcasc-sale potential.

Two main bases of opcration were used during the 1977 season: Cold Bay from June 14 to 18 and Bear Lake Lodge at Port Moller from June 18 to July 8.

Major emphasis was placed on measuring and sampling Tertiary stratigraphic seclions, with a concentration on Miocene and Pliocene exposures. Some older Tertiary and Mesozoic exposures were also examined. Sampies were collected for both a general areal resource cvaluation and more detailed studies in relation to possible petroleum occurrences.

\section{PERSONNEL AND LOGISTICS}

This report combines two sets of elata, In 1974 W. M. Lyle and P. L. Dobcy (DGGS) collected data mostly in the Port Heiden-Chignik area; C. N. Conwell, R. M. Klein, and F. Larson (DGGS) joined this field party for a few days. In 1977 I. F. Palmer and J.G. Bolm (USGS) and W. M. Lyle and J. A. Morehouse (DGGS) collected data from the Cold Bay area northward along the Alaska Peninsula to Unga Isiand, Port Moller, Chignik, and Port Heiden. Ross Schafr, Alaska State Geologist, and D. L. McGee visited the project area in 1977.

The 1977 crew flew to Cold Bay on Reeve Aleutian Airways on June 14. The move to Port Moller area was made on Peninsula Airways Junc 17. Fucl was transported from Seattle to Sand Point, Alaska, by ship and then moved to work arcas with a DeHavilland Orter.

The authors thank Louie Marincovich (USGS) for his idenlification of the macrofossils. 


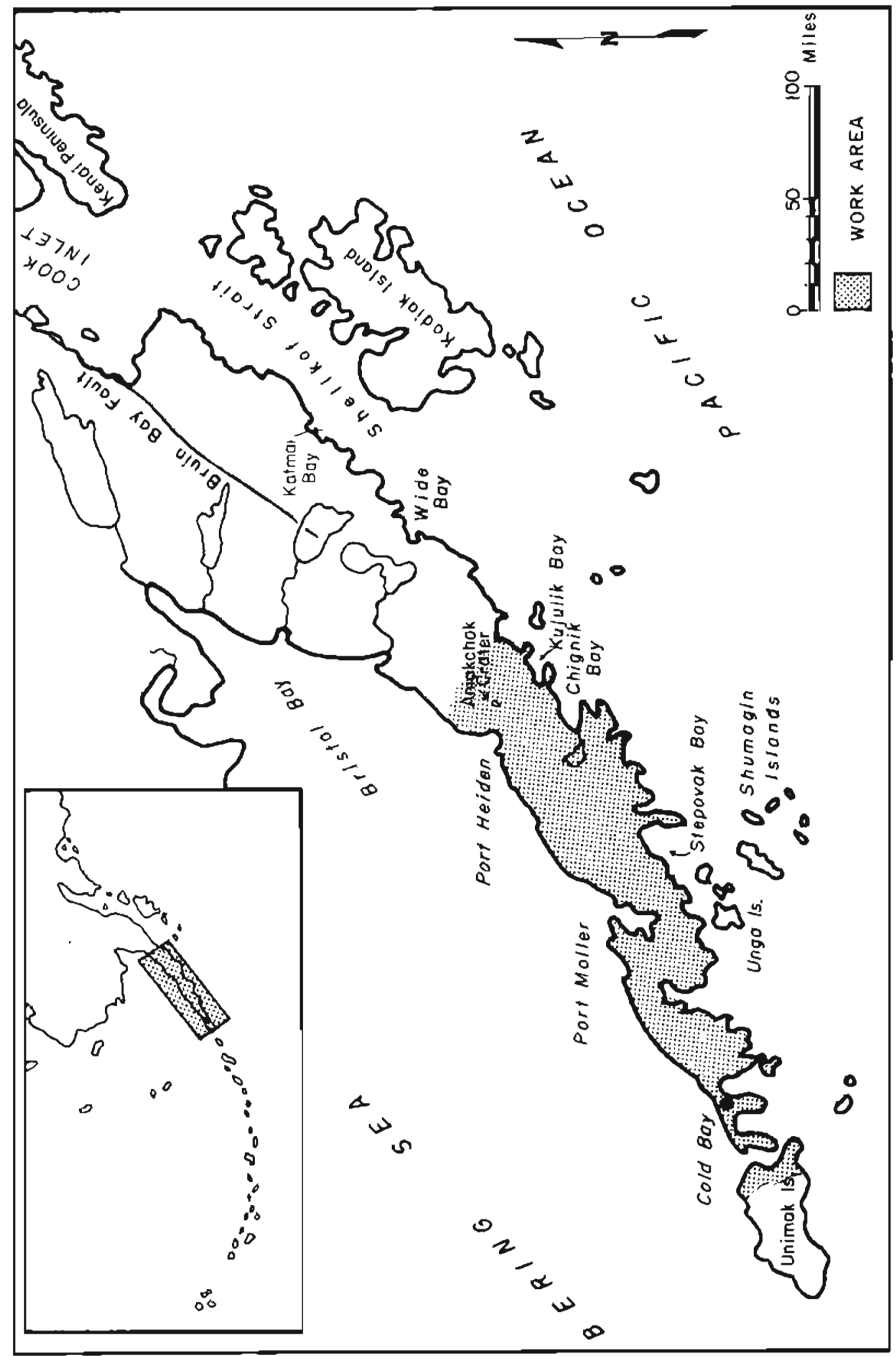

Figure 1. Index map showing the area of the 1977 State-Federal Alaska Peninsula stratigraphic projects. 


\section{FIELD METHODS}

\section{MEASUREMENT OF STRATIGRAPHIC SECTIONS}

Stratigraphic sections were measured primarily with Brunton compass and lape. Occasionally it was neccsary to usc the helicopter altimeter to determinc thickness. All stratigraphic thicknesses recorded on the straligraphic seclions are true thicknesses that were corrected for dip and slope dircetly in the field or at base camp prior to rough ficld drafting of sections. All ficld measurements are in fect and inches to be compatiole with geological logs in common use by industry. A metric conversion scalc is provided on each stratigraphic scetion.

\section{LITHOLOGIC DESCRIPTIONS}

Lithologic descriptions on the stratigraphic sections generally follow the accepted format listed below:

Rock type, descriplive modificr, color (from GSA Rock Color Chart), grain size (cillyer Wentworth grade name or in actual metric measurcments), sorling, lithologic constituents, slatements concern. ing degrec of induration, porosily, and scdimentary structures.

Abbreviations are commonly used to save lime and space; notations such "as above" are freely used when there is litlle obvious difference between units.

\section{SAMPLING}

Samples from stratigraphic sections and spot sample localitics were collected in 7 by 12 -inch or 5 by 7 -inch samplc bags to provide cnough matcrial for laboratory analyses and for sample euls for permanent library reference for both agencies. The "freshest" (least oxidized) samples available werc taken by digging small pits into the outcrops or taking samples below the weather. ing "rind."

The numbering system included the sequence, collector's initials, and year (1-IP.77; 2-WL-77; 3-JB-77; clc.). The 1974 samples had one exception; all the samples on the Black Lake sccion had a 207 prefíx, i.c., 207.21-WL.74; 207.22-WL-74; etc. On a few salmples the lelters $A$ and $B$ were used to denote that more than onc sample was laken at the same locality.

Sample locations are numbered on the quadrangle maps (plates A through F), and cross referenced (rables $1 A$ and $1 B)$.

A tolal of 269 simples were collected: 79 for porosity and permeability determinations, 39 for hydrocarbon analyses, 39 for basin malurily determination, 34 for palynological age determination, 34 for micropalcontological agc determination, 36 for geochemical analyscs,
2 for lithology, 2 for orientation of sandstones, and 4 for macrofossil age dctermination.

\section{STRATIGRAPHY}

Rocks of Jurassic, Crctaceous, and Terliary age crop out in the mountainous area along the Pacific coast of the study area. Stratigraphic sections in the area are interrupted by unconformities beneath formations that are Late Crelaccous, Palcocenc, Miocenc, and Pliocene in agc.

Outcrop patterns of individual formations are conrrolled by large northeast-trending folds, which are the principal features in the area. In the northern part, bedrock is buried beneath the Quaternary glacial and alluvial deposits of the Bering Sea lowlands.

The following descriptions of the various formations that crop out in the study area are based on Burk's memoir of 1965.

\section{NAKNEK FORMATION}

The Naknek Formation is exposed extensively throughout the study area and consists of well to poorly bedded arkosic sandstones, conglomerates, siltstones, and mudstones, which either are interbedded or form relatively thick exposures of a single lichology. Sandsloncs and conglomerate matrices are typically feldspar, quartz, volcanic rock fragments, and chert. Granitic and metamor phic rocks are abundant among coarser clasts in conglomerates, and quartz and feidspar are predominant among coarser clasts in the siltstones and mudstones. Quartz is generally more abundant than feldspar in the finc-grained rock types, whereas feldspar is commonly more abundant than quartz in the sandstones and conglomerates.

The basc of the Naknek Formation is nol exposed anywhere in the study area. The maximum exposed thickness of the formation is about 5,000 feet near Amber Bay, but exposed thicknesses of morc than 9,000 fect are known for the formation in arcas northwest of the study area.

The Naknek is the oldest rock unil exposed in the study area. Sporadically abundant marine pelecypods, belcmnites, gastropods, and ammonites indicate an Ox. fordian to Kimmeridgian age for the formation. The common presence of carbonaceous plant debris and marine fossils suggests a nearshore marine environment of deposition for the formation.

\section{CHIGNIK FORMATION}

The Chignik Formation, welf exposed at many locations, is unconformable to underlying rocks and grades from predominanlly nonmarine near its base to 
marine in its upper part. The Chignik Formation and locally overlying siltstones of the Hoodoo Formation were interpreted by Burk (1965) to be a lypical transgressive marine lithologic sequence, but morc recently Mancini and others (1978) have reinterpreted the Iwo formations to be timc-cquivalent lithofacies representative of deposition in nonmarinc to inner neritic and outer neritic to bathyal environments, respectively.

The largely nonmarinc Coal Valley Member of the Chignik Formation has been interpreted by Burk (1965) to be the basal part of the formation and by Mancini and others (1978) to be a nonmarine facies deposited simul. caneously with the rest of the Chignik and Hoodoo Formalions. The Coal Valley Member is composed primarily of well-bedded sandstones in which large carbonaceous plant fragments are common, often in association with abundant marine fossils. Sedimentary and volcanic rock fragments are major components of these sandstones; carbonate occurs commonly as cement and as a replacement of silicate clasts and may make up as much as 50 percent of the rock. Miner conglomerates, carbonaceous shales, and coal streaks are interbedded with the sandstones of the marine portions of the Chignik Formation.

The Coal Valley Member displays a maximum thick. ness of about 1,200 feet in Coal Valley and the area sou theast of Staniukovich Mountain; it is absent in some locations. The upper marine portion of the Chignik Formation reaches a maximum inickness of about 2,000 tect near Herendcen Bay.

An irregularly abundant marine fauna dominated by pelecypods, principally Inoceramus schmidti, indicates that the Chignik Formation is Campanian.

\section{HOODOO FORMATION}

The Hoodoo Formation (Burk, 1965) is widcly exposed and consists predominantly of well-bedded black and dark gray siltstoncs and shales with some incerbedded fine-grained sandstones and conglomerates. Although slaty cleavage is not developed in the formation, abundant pencil-slatc-like prismatic splinters arc commonly formed by weathering of siltstones (fig, 2). Conglomerates contain typically well-rounded chert and volcanic, granitic, and argillitic pebbles and cobbles and have black siltstone or fine-grained sandstone matrices. Because of the incompetence of the predominant lithologics of the Hoodoo Formation, deformation of the formation is characterized by extremc folding and shcaring which together account for the absence of any known complete and undisturbed stratigraphic section.

The contact between the Hoodoo and Chignik Formations is gradational, and the Hoodoo Formation was interpreted by Burk (1965) to be a more distal facies than the Chignik Formation in a single marine- transeressive sequence; Mancini and olhers (1978) reinterpreted the Hoodoo Formation as a more distal timeequivalent lithofacies in the same stratigraphic interval as the Chignik Formation. D. L. McGec (DGGS report in preparation) accepts both Burk's and Mancini's interpre. tations and suggests that the lower part of the Chignik Formation is time-equivalent to both the lower part of the Hoodoo Formation and the Coal Valley Mcmber rollowed by a transgressive event in which the marine Chignik and Hoodoo Formations overlapped the previously deposited nonmarine Coal Valley Mcmber. This order of deposition best fits the lateral interfingering of the formations and the upward grading of the Cod Valley Member into the Chignik marine sequence. The greatest known thickness of the Hoodoo Formation is more than 2,000 feet and perhaps as much as 3,000 fect in the arca between Herendeen and Pavlof Bays.

Fossils are extremely rare in the Hoodoo Forma. tion, but the few marine pelecypods, cephalopods, and ammonites that are found in the formation suggest an age of Campanian to carly Macstrichtian.

\section{TOLSTOI FORMATION}

The Tolstoi Formation (Burk, 1965) crops out extensively north of Pavlof Bay and consiscs largely of brittle black siltstones made up of poorly sorted andesitic and basaltic volcanic debris with interbedded mafic volcanic flows and sills in some localities. The formation unconformably overlies older formarions and has a thickness of about 5,000 reet everywhere except in the arca soulh of ML. Veniaminof, where it is about iwice that thickness.

Although a rich Palcocene to possibly early Eocene fossil litora was found in this essentially nonmarine formation, middle and late Eocenc marine mollusks were found in two localities. The Tolstoi Formation represents the carly part of a marinc-transgressive lichologic sequence (fig. 3).

\section{STEPOVAK FORMATION}

The Stepovak Formation (Burk, 1965) consists of an alternating sequence of thin-bedded mudstones and massively bedded mudstones and siltstones. It contains several thin coals and many carbonaceous zones lhroughout the section and also some thin petrified wood zones.

The formalion was deposited in the Oligocene under conditions ranging from swampy (as suggested by thin coals and coaly zones) to marine (questionable Foraminifera and shell fragments).

The contact between the underlying Tolstoi Formation and the Slepovak Formation is gradational. The Tolstoi is massively bedded, whereas the Stepovak is thin-bedded. The detrital grains of the Stepovak and the Tolstoi Formations are similar; volcanic rock fragments 
make up about 50 percent of the decrital grains: plagio. clase relelspar (more than 20 percent), yuartz (less than 10 perecnc), and other rock fragments (more than 20 pereent).

\section{BEAR LAKE FORMATION}

The Bear Lake Formation consists of a sequence of rocks ranging from nonmarinc to shallow marinc. Thick. ness cstimates vary from 5,000 to $10,000 \mathrm{fect}$. The oldest rocks of the formation are exposed in the Unga Island-Cape Aliaksin area (Wischart, 1971). Thesc rocks are dominantly volcanic and volcanically derived sediments. This basal part of the formation is Burk's Unga Conglomerate Member of the Bear Lake Formation and has been assigned a middle(?) Miocenc age from marine invertebrate rossil data. Upper Oligocenc(?) plants have also becn reported from Unga Island (Burk, 1965).

In general, the Bear Lakc Formation is a transgres. sive sequence with nonmarine beds, including coal, in the basal part of the section and fossiliferous, marine sandstones in the upper part of the section. l.ocal regressive cycles can also be identified. The secrion contains zones of marine and nonmarine conglomerates. On the Bering Sca side of the study area near Port Moller and Milky River, the section is piedominantly claycy sandstone with lesser amounts of siltstone and conglom. crate. For the most part these sandstones are too friable to permit collection of representative samples for porosity and permeability cvaluation.

The amount of plutonic detritus in the Bedr Lake Formation increascs to the north on the Bering Sea side of the study arca and is interpreted as the initiation of crosion of the mid-Tertiary plutons which had not been unroofed yet during the deposition of the Unga Member. Therefore, the Port Mollcr-Milky River rocks are young. er than those in the Unga Island-Cape Aliaksin area (Wischart, 1971). Burk (1965) came to a similar conclusion using macrofossil and siratigraphic data.

The Poit Moller area rocks represent a regressive sequence that grades upward lrom coarse-grained, largeseale crossbedded sandstone and flaser-bedded siltstones to pyritic silistones and highly fossiliferous conglom. crates (Wischart, 1971).

Rocks of the Bear Lake Formation suggest deposition at the seaward edges of two geographically distinct accreting and subsiding alluvial plains in a tidal deltabarrier bar environment. The sediments deposited on the older of these two plains represent the lower Miocene basal Unga Member of the Bear Lake Formation. They consist of a thick sequence of rapidly deposited debris to the north of the uplifted Shumagin batholith. The younger of the two plains was built northward from a series of quariz diorite plutons that intruded the Unga Member and other sedimentary rocks during the Miocene along a line approximating the prescnt Pacific coastline of the Alaska Peninsula.

The depositional environment for most of the Bear Lake sediments appears to have been that of tidal flats and tidal channels formed in lieu of an of shore barrier bar complex. Quiel water, backshore paludal and fluviatile deposition are indicated by the sediments (Wischart, 1971). Overall agc for the Bear Lake Formation is middle(?) and late Miocenc.

\section{TACHILNI FORMATION}

The Tachilni Formation crops out in sea cliff's along the southeast coast of the Alaska Peninsula west of Cold Bay. The formation consists of poorly consolidated, brown to greenish gray sandstones and conglomerales with minor black shales; volcanic rock fragments and chert are predominant among clasts in the sand and contser size grades.

The basc of the Tachilni Formation is not cxposed, and the top of the formation is gradalional with overlying volcanic rocks. A marine fossil faund, dominated by carly Pliocenc mollusks, is abundant locally in the formation. The ovcrall age of the Tachilni, on the basis of gastropods, is considered to be late Miocene to early Pliocene (Nelson, 1978).

\section{MEASURED STRATIGRAPHIC SECTIONS}

$$
\text { BLACK LAKE (platc 1) }
$$

The Black Lake stratigraphic section is located in sec. 3, T. 43 5, R. 60 W., Seward Meridian. The upper 600-plus feet of the Beal Lake Formation in this section is an alternaring sequence of siltstone and sandstone ([igs, 4 and 5). The topmost 100-plus fect has becn oxidized dark reddish brown and appears to have been heated by contact with nearby intrusive igncous rocks. A 500-foot-1hick massive sandstone unit with some reed imprints and floating pebbles occurs 687 feet below the basc of the Milky River Formation (Galloway, 1974). This unit caps a series of 5- to 25-foot-thick alternating sandstonc and conglomeralc, which in turn overlie a 270-foot-thick conglomeratic sandstone with oscillation ripple marks and carbonaceous trash. The basal 640 fect is a series of massive sandsione and shales with some conglomerate and mudstone.

\section{MJLKY RIVER (plaie II)}

The Milky River straligraphic section is in secs. 33 and 34, T. 48 S., R. 69 W., Seward Meridian. It contains more than 80 percent sandstone, sandy conglomerate, and sandy mudstone. The beds are predominantly massive. The upper section is capped unconformably by volcanic laycrs, tuffs, and waler-deposited volcanicallyderived sandstone (figs. 6 and 7). Pelecypods and gastro- 
pods are commonly present in the upper 158 fect of the scction. Several other thin zoncs also have pelecypods, and some thin zones are coaly or contain petrified wood. The presence of marine fossils and of channcl cut-and-fill sandstones and conglomerates (fig. 8) suggest that the depositional environment ranged from shallow marine to fluvial.

There arc fow mudstones or shales in this measured section. In general, the $\mathrm{C}_{15}$ + extracts from the limiled hydrocarbon source beds of the Bear Lake Formation are moderately high (over $500 \mathrm{ppm}$ average).

\section{SOUTHEAST BEAR LAKE (plate III)}

This measured section is located at the east end of Bear Lakc along a prominent ridge in secs. 20 and $29, T$. 49 S., R. 70 W., Seward Meridian (fig. 9), where the Miocene Bear Lake Formation consists almost entirely of friable sandstone and is capped and preserved by lava flows, mudflows, and ash beds. Locally the section is conglomeratic. Cut-and-fill channel deposits, lenticular sandstone beds, high-angle festoon crossbeds, and the presence of wood and coaly debris indicalc a fluvial environment of deposition for most of the measurcd section. At least 143 feet of the section contains numerous pelecypods, including pectins, and gastropods, which indicate that the depositional environment for this part of the section was marine, probably in the shore-face regime. Zones of fossil hash are also present.

\section{HEREN I and il (plales IV and V)}

The Heren stratigraphic sections are exposed in a sea cliff along the south side of Herendeen Bay near the Heren triangulation station in sec. 9, T. $51 \mathrm{~S}, \mathrm{R} .74 \mathrm{~W}$., Seward Meridian (fig. 10). Heren I stratigraphic scction is composed of interbedded sandstone and mudstone of the Tolstoi Formation that total $143 \mathrm{fcct}$. The basal par1 of this section is grass covered near the beach, and the upper part terminates at a fault that separates Heren I from Heren II. Palynological data indicate a Paleocene(?) or early Eocene(?) age and suggest a marinc environment of deposition. Numerous burrows in one thin sandstone and the presence of coaly streaks and carbonaceous debris suggest a shallow marine to transitional environment.

The Heren II stratigraphic section, which ovcrlies Heren 1 across a fault contact, is 172 feet thick and consists of unnamed interbedded sandstone, mudstone, carbonaceous mudstone, and coal. This section is also Paleocene to early Eocene in age. If the throw on the fault separating the two sections is small (as indicated by limited drag features\}, then a stratigraphic sequence is suggested that begins with shallow marine in Heren I and becomes nonmarine upward into Heren II. These out- crops have previously been mapped as Pliocene by Burk (1965), probably on lithologic characicristics only.

Porosity ranges from 0.3 to 11.8 percent and averages 7.3 percent; permeability ranges from 0.06 to 8.50 $\mathrm{mD}$ and averages $0.95 \mathrm{mD}$.

\section{WATERFALL POINT (Plate VI)}

This measured section is located in secs. 30 and 31 , T. 51 S., R 69 W., Seward Meridian, where the Oligocenc Stepovak Formation is well exposed in clifís at Watcriall Point on the west side of Stcpovak Bay.

The predominant lithologies in this section are olive or grecnish gray, fine to coarse sandstone, dark-gray to black or brownish-black mudstones, and grayish or greenish black silsstones. Sandstones tend to be pebbly, and crossbedding is common. Calcarcous concretions, commonly with ragged surfaces, occur along some bedding surfaces in sandsioncs, and some sandstonc layers are carbonate comented. Fossil marinc pelecypods and to a lesser cxtent gastropods are abundant in some sandstone horizons.

Sandstone samples from this scetion have porositics of 1.7 to 12.1 percent; the sample that tested 12.1 percent porosity is calcareous, and petrographic examination suggests that pore spaces are largely of solution origin and not well connected (permeability for this sample is $0.06 \mathrm{mD}$ ). Organic carbon content of mudstones in this section is very low ( 0.26 to 0.42 percent).

$$
\text { LEFTHAND BAY-BALBOA BAY (plate VII) }
$$

This stratigraphic section is lacated in sec. 29, T. 53 S., R. 73 W., Seward Meridian, where the Stepovak Formation is exposed in a ridge that extends northward from the mouth of Lcfthand Bay (fig. 11). The line along which the section was measured is offset across a covered interval of about $300 \mathrm{fcet}$ stratigraphic thickness near the center of the section.

Mudstone and siltstone are the predominant litholo. gics in the section; these rocks are various shades of olive or greenish gray. Thin sandstone and carbonate beds and carbonate nodules are located in the lower half of the section, and thin bentonite beds and a tuff bed occur in the upper half.

Organic carbon content in samples from this section is very low $(0.23$ to 0.86 percens $)$, and a single sample that was tested had a porosity of 1.7 percent and a permeability of $0.02 \mathrm{mD}$.

\section{BEAVER BAY AND BEAVER BAY EAST (plates VIII and IX)}

The Beaver Bay and Beaver 8ay East straligraphic sections are located in secs. 13, 14, and 24 and secs. 32 
and 33, respectively, in T. $\$ 4$ S, R. 77 W., Seward Meridian (fig. 12). Siltstone and mudstone, typical of the Steporak Formation, predominate. Locally thin sand. stones and conglomerates are present. Carbonaccous debris and petrified wood occur in the nonmarine portion of the section. A minor part of the section contains symmetrical ripple marks and burrows. The environment of deposition ranges from mudflats 10 shallow water marine. The sandstones are generally thin, silty, and of poor reservoir quality.

\section{ALIAKSIN PENINSULA (plate X)}

This measured section is exposed in a prominent sea cliff and is located in sec. 18, T. 54 S, R. 75 W., Seward Meridian (figs. 13-17). The andstone, conglomerate, and conglomeratic sandstone scction is equivalent to the Unga Conglomerale Member of the Bear Lake Formation. The environments of deposition range from shallow marine (as attested by burrows, pelecypods, pectins, and gastropods) to fluvial or delta-plain strcam cut-and-fill deposits with cross-laminations, conglomerate pods, and many boulder and cobble zones. Codl fragments and calbonaccous debris are common in the nonmarinc deposits. A barge percentage of the clasts are volcanogenic. The sands are litable and gencrally yellowish brown to dark gray.

\section{WHITE BLUFF (platc XI)}

The White Bluff stratigraphic section is located in sec. 5, T. 56 S., R. $74 \mathrm{~W}$. and in sec. 32, T. $55 \mathrm{~S}$, R. $74 \mathrm{~W}$., along cast-facing cliff cxposurcs bordering Zachary Bay on Unga Isiand (Sigs. 18-21).

The section tolals 948 rect and consists of interbedded mudstones, sandstones, and conglonerates with minor amounts of coal, tuff, and conglomerate. Onc codly zone is near the base of the section and the other is about 334 feet up in the section. Individual coal beds range from a few inches to 2 fect thick.

Palynological determinations indicatc a nonmarinc depositional environment during a warm palcoclimate in Terliary time (possible Eocene, Oligocene, or middlc Miocone). Sinall cvolutionary changes in the Tertiary pollen spectrum preclude assignment to a single cpoch; lithologic similarities favor assignment of these beds to the Unga Conglomerate member of the Miocenc Bear Luke Formation, however. Approximately onc-lhird of the lotal scction is sandstonc and conglomerate that can be considercd potential reservoir rock. Some sandistoncs are too friable to permit sampling for porosity and permeability. The only sample that survived transport and handling had 4.2 percent porosily and $0.06 \mathrm{mD}$ permeability.

\section{EAST MORZHOVOI BAY (plate XIt)}

This stratigraphic section is located in sec. 35, T. 60 S., R. 90 W., Seward Meridian, where the Miocene to Pliocene Tachilni Formation is exposed in cliffs north of Capc Tachitini on the cast side of the mouth of Morzhovoi Bay (figs. 22-24).

The measured scction, which is offsct about $1 / 1$ mile with an overlap near its center, is predominantly poorly consolidated sandstones, mudstones, and conglomerates; individual beds are so discontinuous laterally that the exact amount of overlap between the two parts of the section cannot be determined. Sandstones in the section are locally calcarcous, commonly pebbly, crossbedded, and, on weathered surfaces, jarosite-stained. Calcareous concretions arc common in the sandstones and conglom. erates. Petrified wood is present in the section, and fossil marine mollusks are abundant in some layers. Minor thin, light brownish or greenish gray claystone beds in the section are probably altercd volcanic ash.

Organic carbon content in mudstone samples from this section is very low (0.28 to 0.69 percent). Much of the sandstone in the section is loo friable for porosity and permcability measurcments. Two samples collected had porositics of 11.6 and 20.1 percent and permeabiliLies of 2.42 and $2.0 \mathrm{mD}$. However, there is almost no visible porosity in these samples.

\section{WEST MORZHOVOI BAY (plate XIII)}

This section is localed in secs. 19 and 30, T. 61 S., R, $92 \mathrm{~W}$, Seward Meridian. The Tachilni Formation section is topped by a 400- to 500-foot-thick serics of resistant volcanic flows and breccias. Angular volcanic clasts arc found in the conglomerates, conglomeratic sandstoncs, and the 35-foot-thick breccia that make up the rest of the scction. Broken shells are found in a 95-Foot-1hick sandy conglomeratc, and some pelecypods in a 45-foot-thick bed of massive sandstone. Several andesite dikes occur in the lower half of the section.

This exposure is considered to be Pliocenc by Burk (1965) and late Miocene to early Pliocene by Nelson (1978).

\section{RESERVOIR CHARACTERISTICS}

Significant thickncsses of porential reservoir rock occur throughour the Alaska Peninsula. Pore-filling cements are pervasive throughout most of the outcrop samples examined, but selecied outcrop samples and well log analyscs indicate that the porosity of some of the potential reservair rock has been preserved. This prescrvation could have resulted from carly migration of hydrocarbons, although there is no evidence to support this. 


\section{RESERVOIR GEOMETRY ANO SIZE}

Mcasured sections and well data indicate that thick reservoirs should be present in the Miocene Bear Lake Formation. Grcater quartz content and types of depositional environments of deposilion make this formation a primary drilling objective. Potential reservoirs should have the large areal extent typical of tabular sand bodics that result from linear clastic shorcline deposition. Geormetry consistent with beaches, upper and middic shorcface deposits, and offshore bars should be present in the subsurface.

The Stepovak Formation has very thin sandstones and sandstone stringers that are not expected to have good reservoir characteristics.

Some massive sandstones that are present in the Tolstoi and Chignik Formations are of poor quality onshore but cannot be ruled out as possible reservoir rock in nearby submerged lands. Onc or more stratigraphic tests will be needed offshore to evaluate the reservoir quality of these rocks.

Discrete sandstone thickness determinations and sandstone percentage determinations have been made for the stratigraphic sections measured. These determinations are all for Tertiary sandstones ranging in age from Paleocene(?) or Eocene(?) to Pliocene. Sands tone thicknesses have been grouped into three thickness categorics: 0-15 meters, 15.30 mcters, and greater than 30 ineters. These data are tabulated on Table 2.

The percentage of sandstone in the total stratigraphic section measurcd ranges from less than 1 percent to 100 percent and averages 62.8 percent for all ages (table 2).

\section{RESERVOIR POROSITIES AND PERMEABILITIES}

The porosities and permedbilities (table 3) range from low to fair in the Tolstoi and Sieporak Formations to fair to good in the Bear Lake Formation. The Bear Lake Formation is friable and difficult to sample. Perme. ability is very low to nonexistenc in the Tolstoi and Stepovak Formations and low in the Bear Lake Formation except for three high permeabilities of 990,72, and $53 \mathrm{mD}$. Most samples had permeabilitics of less than 1 millidarcy.

\section{RESERVOIR STRUCTURE AND SPATIAL RELATIONSHIP}

All the stratigraphic sections in this report were measured in either homoclinal dip areas or on the limbs of folds where comparison of units or bed sequences was not possible between the different flanks of a structure. Deposition during the Tertiary was sporadic and complex.
General obscrvations indicale that there are no preferential arcas, directions, or flank positions where reservoir rocks are preserved. Transitional and strandline sand bodies should be oriented roughly parallel to the existing Alaska Peninsula shorcline (Selley, 1970). Fluviat sand bodics should have an oricntation normal to the existing coastline, as should offshore decpwater turbidite deposits (Middicion and orhers, 1973). In gencral, all surface structure post-dates reservoir deposition.

\section{BASIN MATURITY}

Kelogen-type assessment and thermal alteration index (TAl) determinations were run on the 69 samples collected from stratigraphic sections and spot sample locations. Fifty-cighl samples are from Tertiary exposures, and 1 i samples are from Cretaccous outcrops. The Tertiary samples have a TAl level thac ranges from 1 to 3- will an average of 2. (A TAl level of 2 cquates to a moderately mature hydrocarbon-maturation level.) Cretaccous samples have a range of 2- to 3t. These alteration levels equate to a moderately mature to a very mature maturation Icvel.

Kerogen constituents in all samples are dominantly herbaccous-spore/culicle with secundary, amphorous, woody, or coaly grains. Thus, the most likely hydrocarbon to be generaled is dry gas. There are, however, significant amounts of amphorous material present in most of the samples, which suggest the capability for generation of some liquid hydrocarbons.

Table 4 shows the kerogen assessment as processed by Geochemical Laboraturics Inoorporated.

\section{HYDROCARBON SOURCE ROCKS}

Source rocks on the Alaska Peninsula range from fair to good, from 37 to $2,984 \mathrm{ppm}$ hydrocarbon. The average for 69 samples is $362.3 \mathrm{ppm}$ hydrocarbon.

An analysis of hydrocarbon content by rock age indicates that hydrocarbon content is higher in youngeb rocks:

Jurassic and Cretaccous $\quad 105 \mathrm{ppm}$ (11 samples)

Eocene

Oligocene

Miocene

Pliocene

No data

290 ppm (26 samples)

$550.5 \mathrm{ppm}$ (27 samples)

$627 \mathrm{ppm}$ (4 samples)

The highest values of $2,984,1,947$, and $1,372 \mathrm{ppm}$ occurred in the Miocene Bear Lake Formation. The lowest values 55 through 89 were in the Cretaccous Hoodoo Formation.

\section{STRUCTURAL GEOLOGY}

The study area is the site of cxtensive volcanism, and the sedimentary rocks of the arca have been folded, 
faulted, and intruded by plutonic and hyoabyssal rocks. The general strucural relationships in the area have been described by Burk (1965), and the Tollowing outline is based on his work.

Threc en echelon anticlinal complexes that deform rocks of Middle or Latc Jurassic to Pliocene age are the principal structures in the study arcd. These anticlinal complexes are located between Katmai Bay and Aniakchak Crater, between Kujulik Bay and Stepovak Bay, and belwecn Stcpovak Bdy and Cold 8ay. Fold axes in these complexes trend generally northeastward and diverge slightly in a clockwise sense from the ax is of the peninsula; fold style secms to vary in relation to rack compctence, with shales and silisiones more tightly foided than sandstomes and conglomerales.

Major stecply dipping reverse longitudinal faults are located in the southern flanks of most anticlines. Displacement across these faul's is generally greatest near the culminations and decreases loward the noses of the folds. Sinaller stecply dipping normal longitudinal faults are located in the northein flanks or some anticlines.

The abundance of stecply dipping reverse and normal faults and a tendency of anticlines to have broad crests and monoclinal flanks suggest that bascment faulling may have played an important role in the structural development of the study arca. Plutions of Jurassic, carly Tertiary, and middic Tertiary age crop out in or adjacent to the study area, and it is evident that extensive differential vertical movements have occurred in the area following exch period of plutonism.

Outcrops of plutonic rocks of various ayes are located along discernible trends: Jurassic plutons crop out along the peninsular axis, lower Tertiary plutons crop out in islands soulheast of the peninsula, and middlc Tertiary plutons crop out along the southeastern coast of the peninsula. Similarly, recent volcanoes tend to be aligned along and older volcanoes somewhat southeast of the axis of the peninsula. No consistent general relationship between plutonic or volcanic igneous activity and structural configuration has been dercel. ed in the study area, however.

\section{PETROGRAPHY}

Forty-six samples of sandstones from measured stratigraphic sections and spot localities in the study area were examined petrographically. Of these 46 samples, 2 were from the Naknek Formation at Bold Bluff Point on Herendecn Bay; 5 were from the Chignik Formation at Gull Point on Herendeen Bay and the low sea cliff of Staniukovich Mountain; 14 were from the Tolstoi For. mation in the Heren I and II stratigraphic sections and at an unnamed mountain northwest of Bcaver Bay; 9 were from the Stepovak Formation in the Beaver Bay and Waterfall Point stratigraphic sections; 12 were from the
Bear Lake Formation in the Black Lake and Milky River stratigraphic sections; and 4 were from the Tachilni Formation in the East and West Morzhovoi Bay stratigraphic sections. Sample locations and a summary of petrographic data for representative samples are present. ed in Table 5.

Framework clasts in all the samples are dominated by chemically unstable constituents indical ive of deriva. tion from predominantly igneous source terrancs, varia. tions in which are reflected in differences in the clastic compositions of samples from the various studied formations. The arkoses of the Naknek Formation are compositionally similar to typical quartzose intermcdiate granitic rocks with a slight admixturc of volcanic clasts, and it is cvident that Naknek sediments werc derived from a predominantly plutonic source. The sandstones of the Chignik formation are characlerislically litharenites in which volcanic and fine-grained sedimentary clasts predominate, and a mixed volcanic and scdimentary source terrane is indicatcd. Sandstones in the Tertidry formations are volcanic arenites dominated by volcanic clasts, which indicates a volcanic source area; a parlicular abundance of quartz in samples from the Bear Lake Formation suggests that significant recycling of older sedimentary rocks may have playcd a role in the deposition of that formation. Pumpellyite was observed among clasis in samples from the Tolstoi and Tachilni Formarions, and a glaucophane clast was seen in one sample from the Stepovak Formation; some zcolite- and blucschist-facies rocks must have cropped out somewhere in the source terranes of these formations.

There is litule visible pore space in any of the samples examined; most simples have no visible pore space. This lack of visible porosity is the result of deformation of ductile clasts, primarily volcanic or scdimentary rock fragments, during compaction and filling of any remaining potential pore spaces with various ferruginous, phyllosilicate, tectosilicate, and carbonatc materials. Thesc features, which have caused the low visible porosities (and low measured permeabilities) of the samples, have resulted from diagenesis of the rocks; there may be better porosity in similar sandstones in the subsurface or offshore in adjacent OCS (Outer Continental Shelf) areas.

For every formation studied, except the Naknek (from which only two samples were examined), there are samples in which porosity has been reduced either by ductile grain delormation or by filling of potential pore spaces. The more authigcnic pore-filling material there is in a sample, the less deformed are the ductile grains in that sample. In these samples compaction was accomplished largely by ductile grain ceformation after burial; the introduction of authigenic pore-filling material ar. rested such grain deformation and prevented further compaction. 
Pore-filling phases in the samples include amorphous ferruginous material, authigenic clays (including chlorite), carbonate, zcolite, quartz, and authigenic albite. Amorphous ferruginous matcrial and authigenic clay commonly coat clasts and gencrally underlic and thus predate any other pore-filling phases that may be presenr; these two materials and carbonate are the only pore-filling phases that were observed alone in any of the samples. Quartz was observed in partial syntaxial over. growths on some quartz clasts but was never scen to form a complete cement in any samples; such syntaxial overgrowths may have formed during a previous scdimentary cycle.

In several samples where two or more pore-filling phases coexist, lexiulal evidence such as cmbayments indicales a replacement relationship among the phases; replacement or parlial replacement of framework clasts by pore-filling materials is common in the samples, too.

Intragranular fractures were observed in many of the samples. Such fractures are filled with the same pore-filling materiats as fills potential interyranular pore spaces in the same sample; thus fracturing occurred prior to emplacement of the pore-filting matcrials. In scveral of these samples duclile grains are litule deformed, and fracluring must have occurred as a result of partial dissolution of the rock after cementation had arrested deformation of ductile clasts. Further cementation af ter fracluring brought rocks to their present configuration. The past existence of secondary porosity is further indicated in some samples by the occurrence within pore-filling carbonate or zeolite of fragments of clay coats broken away from elast sulfaces, and the large size of some intergranular spaces suggests that they were formed by dissolution after primary compaction had ceased. In none of the samples where compaction by ductile grain deformation was completed is there any evidence of secondary porosily ever having existed.

The formation of secondary porosity results from changes in the physical and chemical conditions in a rock such that a material that was once stable becomes unstable and is dissolved away. Similarly the filling of secondary porosity requires certain physical and chemical conditions to precipitate the pore. filling phase. Both these types of changes have occurred in at least some of the samples studied, and burial and uplift probably figured significantly in achieving and changing physical and chemical conditions in the samples. In onc sample (23-WL-77, Stepovak Formation, Beaver Bay) there are two generations of carbonate ccment separated by a layer of authigenic chlorite, which also fills intragranular fractures. Early carbonate cementation prevented complete destruction of intergranular spaces by ductile grain deformation, and subsequently, secondary porosity was formed by dissolution of carbonate. As secondary porosity became more extensive, renewed compaction led to the formation of intragranular fractures, but infilling of secondary pores and intragranular fractures with chlorite prevented completion of compaction. Finally chlorite was replaced by carbonate, but the process was not completed. The change from conditions where carbonalc was precipitated to those where it was dissolved and rinally to where chlorite was precipitated all probably resulted from increasing depth of burial. Similarly the return to conditions favoring the precipitation of carbonate probably resulted from uplift. This sample might have had significant porosity today had it remained at some depth where carbonate was soluble and chlorite not yet stable. Such secondary porosity may exist at least locally in similar rocks at depths favorable for the formation of petrolcum reservoirs in offshore areas adjacent to the study area.

\section{GEOCHEMICAL ANALYSES}

One hundred and eight stream sediment and two whole rock samples were analyzed for the presence of gold, silver, copper, lead, zinc, molybdenum and antimony (Lable 6). Sample 55-19.77, from Unga mine tailings, is not a stream-sediment sample.

\section{PALEONTOLOGICAL DETERMINATIONS}

A total of 19 outcrop samples were proccssed and analyzed for palynological age determinations (table 7). All samples with definable ages were from Tertiary strata.

As the results in Table 7 show, the nonmarinc Tertiary samples are difficule to place in any defined agc subdivision. In the Alaska Peninsula study area, the nonmarine Tertiary section displays slight or no evolutionary changes in the pollen spectrum. In Oligocene and younger strala, we are dealing inainly with climatic fluctuations, whereas a few unique specics may be used in distinguishing Paleocene or Eocene strata. Due to these faclors, it is impossible to assign any given sample to a single epoch. Other information, such as sample location on columnar sections or geologic maps, could assist in age interpretations of floras. It is also desirable to have sufficient section coverage in sampling so that a known or reliably definable age boundary is crossed; this boundary can then be used as a datum to which the other unknowns may be related.

Table 8 lists the macrofossils found in samples from the Bear Lake, Stepovak, and Talchilni Formations.

\section{GRAVITY CONTROL}

Gravity values from over 200 newly occupied stations during the 1977 field season are currensly being reduced and integrated with previous gravity surveys 
conducted by the Alaska DGGS in 1974 and by the U.S. Geological Survey. Bouguer gravity will be determined with a common datum for all gravity surveys conclucled over the project area. Gravity data and interpretation maps will be published when computer programming and data compilation are completed.

\section{CONCLUSIONS}

During the 1977 State-Federal Alaska Peninsula field project, stratigraphic sections totaling $16,000 \mathrm{fect}$ $(5,000 \mathrm{~m})$ were measured and 269 samples were collected and analyzed. Significant new data were obtained on petrolcum-reservoir and sourcc-rock potential, deposilional environments, paleontological age dating, struczural geology, petrographic and diagenetic characteristics, geochemical control, and gravity control.

Porosity and permcability analyses on most samples indicate a range of poor to fail rescrvoir polential. A few samples of Miocene age have good porosity and permeability. Thick potential rescrvoir sands werc measurce al several locations; however, the offshore extensions of porous sandstones arc unknown.

Source-rock potential is considered good. Kerogen assessment lavors the gencration of gas as the major bydrocarbon type. Mosi samples analyzed for maturity (TAl method) indicate a submature to mature range of maturation.

We conclude that the offshore area adjacent to the Alaska Peninsula is a good place to explore for hydrocarbons.

\section{REFERENCES}

Burk, C. A., 1965, Geology of the Alaska Peninsulaisland are and continental margin: Geol. Soc. America Mem. 99, 250 p.

Galloway, W. E., 1978, Deposition and diagenetic alteration of sandstone in northeast Pacific arc-related basins: Geol. Soc. America Bull., v. 85, no. 3, p. 379-390.

Goddard, E. N., Chairman, 1970, Rock-color chart: Geol. Soc. America, $7 p$.

Mancini, E. A., Deete, T. M, and Wingate, F. H., 1978, Upper Cretaceous arc-trench gap sedimentation on the Alaska Peninsula: Gcology, v. 6, p. 437-439.

Middleton, G. V., and others, 1973, Turbidites and deep water scdimentation: Soc. Econ. Palcontologists and Mineralogists, Pacific section, short course, $157 \mathrm{p}$.

Nelson, C. M., 1978, Neptunea (Gastropoda: Buccinacca) in the Neogene of the North Pacific and adjacent Bering Sea: The Veliger, v. 1, no. 2, p. 203-215.
Selley, R. C., 1970, Ancient sedimentary environments: Chapman and Hall Ltd., London, 224 p.

Wisehart, R. H., 1971, Paleoenvironmental analysis of the Bear Lake Formation (upper and middle Mio. cene), Alaska Peninsula, Alaska: M.S. thesis, University of California at Los Angeles. 
TABLE 1 A AND 1B-CROSS REFERENCE

TABLE IA-MAP NUMBERS TO SAMPLE OR STATION NUMBERS

\begin{tabular}{|c|c|c|}
\hline \multicolumn{3}{|c|}{ USHAGIK QUADRANGLE (PLATE A) } \\
\hline \multicolumn{3}{|c|}{ Random Sampling } \\
\hline Map No. & $\begin{array}{l}\text { Sample or } \\
\text { Station No. }\end{array}$ & $\begin{array}{l}\text { Analysis or } \\
\text { Measurement }\end{array}$ \\
\hline 1 & $65-1 P \cdot 77$ & Palynology \\
\hline 1 & $66-1 P-77$ & Hydrocarbon \\
\hline 1 & $67-1 P \cdot 77$ & $\begin{array}{l}\text { Porosity and } \\
\text { permeability }\end{array}$ \\
\hline 2 & $62-1 P-77$ & Palynology \\
\hline 2 & $63-1 P \cdot 77$ & Hydrocarbon \\
\hline 2 & $64-1 P-77$ & $\begin{array}{l}\text { Porosity and } \\
\text { permeability }\end{array}$ \\
\hline
\end{tabular}

Random Sampling

$\begin{array}{cl} & \text { Sample or } \\ \text { Map No. } & \text { Station No. } \\ 3 & \text { PH Base } \\ 4 & \text { PH12 } \\ 5 & \text { PH11 } \\ 6 & \text { PH10 } \\ 7 & \text { PHO9 } \\ 8 & \text { PH13 } \\ 9 & \text { PHO6 } \\ 10 & \text { PHO7 } \\ 11 & \text { PHO8 } \\ 12 & \text { TRI.\#213* } \\ 13 & \text { TRI.\#211 } \\ 14 & 38-J B-77 \\ 15 & 39-J B-77 \\ 16 & 40-J 8-77 \\ 17 & 41-J 8-77 \\ 18 & 42-J B-77 \\ 19 & 43-J B-77 \\ 20 & \text { PHO3 } \\ 21 & \text { PH04 } \\ 22 & \text { PHO5 } \\ 23 & \text { PHO6 } \\ 24 & \text { TRI.\#211 } \\ 25 & \text { TR . } 210 \\ 26 & 33-J B O-77 \\ 27 & 34 J \text { J }-77 \\ & \end{array}$

Gravity

Gravity

Gravity

Gravity

Geochemical

Geochemical

Geochemical

Geochemical

Geochemical

Geochemical

Gravity

Gravity

Gravity

Gravity

Gravity

Gravity

Geochemical

Geochemical
Sample or

Map No. Station No.

35- $1 \mathrm{~B}-77$

36.JB-77

36- $\{\mathrm{B}-77$

32-JB-77

45- 10.77

46-J日- 77

47.-18.77

PHO1

$\mathrm{PH} 02$

48-JB-77

PHT 4

TRI. 189

30. $\mathrm{B}-77$

29. $18-77$

TRI. \#197

283-WL.74

284WL-74

TRI. \#205

41
42

Black L
43

43

43

43

43

43

43

43

43

\section{5-WL-77 \\ 6-WL-77 \\ 7-WL-77 \\ 8-WL-77 \\ 9-WL-77 \\ 10-WL-77 \\ 11-WL-77 \\ 12-WL-77 \\ 13-WL-77 \\ 14-WL-77}

15.WL-77

16-WL-77

17.WL-77

18-WL-77

43

43

43

43

43

43

43

43

43

19-WL-77
31-JB-77

Analysis or

Measurement

Geochemical

Geochemical

Geochemical

Geochemical

Geochemical

Geochemical

Geochemical

Gravity

Gravity

Geochemical

Gravity

Gravity

Geochemical

Geochemical

Geochemical

Gravity

Density; magnetic susceptibility

Geochemical

Gravity

(Plate 1) Sampies

Lithology

Paleontology

Paleontology

Hydrocarbon

Paleontology

Paleontology

Hydrocarbon

Porosity and permeability

Porosity and permeability

Porosity and permeability

Macrofossil

Macrofossil

Porosity and permeability

Porosity and permeability

Lithology

Porosity and permeability

Lithology

Lithology

Geochemical

Geochemical

Porosity and permeability

Hydrocarbon 


\begin{tabular}{|c|c|c|c|c|c|}
\hline Map No. & $\begin{array}{l}\text { Sample or } \\
\text { Station No. }\end{array}$ & $\begin{array}{l}\text { Analysis or } \\
\text { Measurement }\end{array}$ & Map No. & $\begin{array}{l}\text { Sample or } \\
\text { Station No. }\end{array}$ & $\begin{array}{l}\text { Analysis or } \\
\text { Measurement }\end{array}$ \\
\hline 43 & 207.8-WL-74 & $\begin{array}{l}\text { Porosity and } \\
\text { permeability }\end{array}$ & $\begin{array}{l}52 \\
52\end{array}$ & $\begin{array}{l}\text { TRI. } 196 \\
275-\text { WL }-74\end{array}$ & $\begin{array}{l}\text { Gravity } \\
\text { Office sample }\end{array}$ \\
\hline 43 & 207.9-WL-74 & $\begin{array}{l}\text { Porosity and } \\
\text { pcrmcability }\end{array}$ & $\begin{array}{l}54 \\
55\end{array}$ & $\begin{array}{l}\text { 274-WL.74 } \\
\text { TRI. \#225 }\end{array}$ & $\begin{array}{l}\text { Office sample } \\
\text { Gravity }\end{array}$ \\
\hline 43 & $207.10 \cdot$ WL.74 & Lithology & 56 & 263.WL-74 & Geochemical \\
\hline 43 & $207.11 \cdot W L-74$ & $\begin{array}{l}\text { Porosity and } \\
\text { permeability }\end{array}$ & 56 & $264-W L-74$ & $\begin{array}{l}\text { Porosity and } \\
\text { permeability }\end{array}$ \\
\hline 43 & $207.12-W L-74$ & $\begin{array}{l}\text { Porosily and } \\
\text { pcrmeability }\end{array}$ & 56 & 265-WL-74 & $\begin{array}{l}\text { Density; magnetic } \\
\text { susceptibility }\end{array}$ \\
\hline 43 & 207.13-WL-74 & Macrofossil & 56 & 266-WL-74 & Officc sample \\
\hline 43 & 207.14-WL-74 & Macrofossil & 56 & $267-W L-74$ & Hydrocarbon \\
\hline 43 & $207.15 \cdot$ WL-74 & Macrofossil & 57 & TRI.\#193 & Gravily \\
\hline 43 & $207.16-W L-74$ & Macrofossil & 57 & 269-WL-74 & Geochemical \\
\hline 43 & 207.17-WL-74 & Lithology & 58 & MR03 & Graviry \\
\hline 43 & 207.18 WL-74 & $\begin{array}{l}\text { Porosity and } \\
\text { permcability }\end{array}$ & $\begin{array}{l}59 \\
60\end{array}$ & $\begin{array}{l}\text { MR0S } \\
\text { TRI.\#178 }\end{array}$ & $\begin{array}{l}\text { Gravity } \\
\text { Gravity }\end{array}$ \\
\hline 43 & 207.19-WL-74 & Lithology & 61 & MR10 & Gravity \\
\hline 43 & 207.20 WL -74 & $\begin{array}{l}\text { Porosity and } \\
\text { permeability }\end{array}$ & $\begin{array}{l}62 \\
63\end{array}$ & $\begin{array}{l}49-1 \mathrm{~B}-77 \\
\text { MR11 }\end{array}$ & $\begin{array}{l}\text { Geochemical } \\
\text { Gravity }\end{array}$ \\
\hline 43 & 207.21-WL-74 & Lithology & 64 & MR12 & Gravily \\
\hline 43 & 207.22-WL-74 & $\begin{array}{l}\text { Porosity and } \\
\text { permeability }\end{array}$ & $\begin{array}{l}65 \\
66\end{array}$ & $\begin{array}{l}\text { PHI15 } \\
\text { TRI.\#198 }\end{array}$ & $\begin{array}{l}\text { Gravily } \\
\text { Gravity }\end{array}$ \\
\hline 43 & $207.23 \cdot$ WL-74 & $\begin{array}{c}\text { Density; magnetic } \\
\text { susceptibility }\end{array}$ & 66 & 276-WL-74 & Geochemical \\
\hline 43 & 207.24-WL-74 & $\begin{array}{l}\text { Porosity and } \\
\text { permeability }\end{array}$ & $\begin{array}{l}67 \\
67\end{array}$ & $\begin{array}{l}\text { TRI. \#199 } \\
277-W L .74\end{array}$ & $\begin{array}{l}\text { Gravity } \\
\text { Geochemical }\end{array}$ \\
\hline 43 & $207.25-W L-74$ & $\begin{array}{l}\text { Porosity and } \\
\text { permeability }\end{array}$ & $\begin{array}{l}68 \\
68\end{array}$ & $\begin{array}{l}\text { TRI. } 200 \\
278-W L-74\end{array}$ & $\begin{array}{l}\text { Gravity } \\
\text { Geochemical }\end{array}$ \\
\hline 43 & 207.26-WL-74 & Lithology & & & \\
\hline 43 & 207.27-WL-74 & $\begin{array}{l}\text { Porosity and } \\
\text { permeability }\end{array}$ & $\begin{array}{l}69 \\
69\end{array}$ & $\begin{array}{l}T R I . \# 206 \\
285-W L-74\end{array}$ & $\begin{array}{l}\text { Gravity } \\
\text { Geochemical }\end{array}$ \\
\hline 43 & $207.28-W L-74$ & $\begin{array}{l}\text { Porosity and } \\
\text { permeability }\end{array}$ & $\begin{array}{l}70 \\
70\end{array}$ & $\begin{array}{l}\text { TRI. } 209 \\
292-W L-74\end{array}$ & $\begin{array}{l}\text { Gravity } \\
\text { Geochemical }\end{array}$ \\
\hline 43 & $207.29 \cdot$ WL-74 & Hydrocarbon & 70 & $293 \cdot$ WL.74 & Age date \\
\hline 43 & 207.30-WL-74 & Hydrocarbon & 70 & 294-WL-74 & Geochemical \\
\hline 43 & $207.31-W L-74$ & $\begin{array}{l}\text { Porosity and } \\
\text { pormeability }\end{array}$ & $\begin{array}{l}70 \\
70\end{array}$ & $\begin{array}{l}295-W L-74 \\
296-W L-74\end{array}$ & $\begin{array}{l}\text { Density } \\
\text { Magnetic }\end{array}$ \\
\hline 43 & $207,32 \cdot$ WL-74 & Lithology & & & susceptibility \\
\hline 43 & 207.33-WL-74 & Hydrocarbon & 70 & DT $74-6$ & $\begin{array}{l}\text { Density; magnetic } \\
\text { susceptibility }\end{array}$ \\
\hline \multicolumn{3}{|c|}{ Random Sampling } & 70 & DT $74-5$ & Density; magnetic \\
\hline 44 & 318-WL-74 & Geochemical & & & susceptibility \\
\hline $\begin{array}{l}45 \\
45\end{array}$ & $\begin{array}{l}\text { TRI. } 192 \\
268-W L-74\end{array}$ & $\begin{array}{l}\text { Gravity } \\
\text { Gcochemical }\end{array}$ & 70 & 297-WL. 74 & $\begin{array}{c}\text { Density; magnetic } \\
\text { susceptibility }\end{array}$ \\
\hline 46 & MRO6 & Gravity & 70 & 298-WL.74 & Geochemical \\
\hline 47 & MRO7 & Gravity & 70 & 299-WL-74 & Density; magnetic \\
\hline $\begin{array}{l}48 \\
49 \\
50\end{array}$ & $\begin{array}{l}\text { MR08 } \\
\text { MR09 } \\
\text { TRl. \#223 }\end{array}$ & $\begin{array}{l}\text { Gravity } \\
\text { Gravity } \\
\text { Gravity }\end{array}$ & $\begin{array}{l}70 \\
71\end{array}$ & $\begin{array}{l}\text { 300-WL-74 } \\
288-W L-74\end{array}$ & $\begin{array}{l}\text { susceptibility } \\
\text { Geochemical } \\
\text { Geochemical }\end{array}$ \\
\hline 50 & 315-WL.74 & Geochemical & 71 & 289-WL.74 & Age date \\
\hline 51 & TRI. \#224 & Gravity & 71 & $290-W L-74$ & Densily \\
\hline
\end{tabular}




\begin{tabular}{|c|c|c|c|c|c|}
\hline Map No. & $\begin{array}{l}\text { Sample or } \\
\text { Starion No. }\end{array}$ & $\begin{array}{l}\text { Analysis or } \\
\text { Measurement }\end{array}$ & Map No. & $\begin{array}{l}\text { Sample or } \\
\text { Station No. }\end{array}$ & $\begin{array}{l}\text { Analysis or } \\
\text { Measurement }\end{array}$ \\
\hline 71 & 291-WL-74 & $\begin{array}{l}\text { Magnetic } \\
\text { susceptibility }\end{array}$ & 89 & 305-WL-74 & $\begin{array}{l}\text { Magnetic } \\
\text { susceptibility? }\end{array}$ \\
\hline 72 & TRI. \#204 & Gravity & 89 & 306-WL-74 & Geochemical? \\
\hline 72 & 285-WL-74 & Geochemical & 90 & 307-WL-74 & Density \\
\hline 73 & TRI. 190 & Gravity & & & susceptibility \\
\hline 73 & 259-WL-74 & Geochemical & 90 & 309.WL.74 & Geochemical \\
\hline 73 & 261-WL-74 & Densily & 90 & 310.WL.74 & Geochemical \\
\hline 73 & 262-WL-74 & Office sample & 91 & $371-W L-79$ & Density \\
\hline 74 & 314.12-WL-74 & Geochemical & 91 & 312-WL-74 & Geochemical \\
\hline $\begin{array}{l}74 \\
75\end{array}$ & $\begin{array}{l}314.13-W L-74 \\
314-W L-74\end{array}$ & $\begin{array}{l}\text { Geochemical } \\
?\end{array}$ & 91 & 313-WL-74 & $\begin{array}{l}\text { Magnetic } \\
\text { susceptibility }\end{array}$ \\
\hline 75 & 314. 1-WL-74 & Density & 92 & MRO2 & Gravily \\
\hline 75 & 314.2-WL-74 & Office sample & 93 & TRI.\# 147 & Gravity \\
\hline 75 & 314.3-WL-74 & $\begin{array}{l}\text { Porosity and } \\
\text { permeability }\end{array}$ & $\begin{array}{l}94 \\
95\end{array}$ & $\begin{array}{l}\text { TRI. \#182 } \\
\text { TRI. \#184 }\end{array}$ & $\begin{array}{l}\text { Gravity } \\
\text { Gravity }\end{array}$ \\
\hline $\begin{array}{l}75 \\
75\end{array}$ & 314.4-WL-74 & Density & $\begin{array}{l}95 \\
96\end{array}$ & $\begin{array}{l}248 \cdot W L-74 \\
\text { PH16 }\end{array}$ & $\begin{array}{l}\text { Geochemical } \\
\text { Gravity }\end{array}$ \\
\hline $\begin{array}{l}13 \\
75\end{array}$ & $\begin{array}{l}\text { 314.5-WL-74 } \\
314.6-W L-74\end{array}$ & $\begin{array}{l}\text { Paleontology } \\
\text { Geochemical }\end{array}$ & 97 & MR16 & Gravity \\
\hline 76 & 314.7-WL-74 & $\begin{array}{l}\text { Porosity and } \\
\text { permeability }\end{array}$ & $\begin{array}{l}98 \\
99\end{array}$ & $\begin{array}{l}\text { TRI. \#5 } \\
\text { TRI.\# } 185\end{array}$ & $\begin{array}{l}\text { Gravity? } \\
\text { Gravity }\end{array}$ \\
\hline 76 & $314.8-W L-74$ & Density & 99 & 249-WL-74 & Geochemical \\
\hline 76 & 314.9-WL.74 & Magnetic & 99 & 250-WL-74 & Geochemical \\
\hline $\begin{array}{l}76 \\
76 \\
76 \\
77\end{array}$ & $\begin{array}{l}314.10-W L-74 \\
\text { DT-74-15 } \\
314.11-W L-74 \\
\text { TRI. \#183 }\end{array}$ & $\begin{array}{l}\text { susceptibility } \\
\text { Density } \\
\text { Age date } \\
\text { Geochemical } \\
\text { Gravity }\end{array}$ & $\begin{array}{l}100 \\
100 \\
100 \\
100 \\
100\end{array}$ & $\begin{array}{l}\text { TRI.\# } 186 \\
251-W L-74 \\
252-W L-74 \\
253-W L-74 \\
254-W L-74\end{array}$ & $\begin{array}{l}\text { Gravity } \\
\text { Geochemical } \\
\text { Hydrocarbon } \\
\text { Office sample } \\
\text { Age date; }\end{array}$ \\
\hline $\begin{array}{l}78 \\
79\end{array}$ & $\begin{array}{l}\text { MRO4 } \\
\text { TRI. } 179\end{array}$ & $\begin{array}{l}\text { Gravity } \\
\text { Gravity }\end{array}$ & & & $\begin{array}{l}\text { density; magnetic } \\
\text { susceptibility }\end{array}$ \\
\hline 80 & TRI.\#180 & Gravity & 101 & TRI.\# $\{87$ & Gravity \\
\hline 81 & TRf.\#181 & Gravity & 101 & 255-WL-74 & Float \\
\hline 82 & MR13 & Gravity & 101 & 256-WL-74 & Geochemical \\
\hline $\begin{array}{l}83 \\
84 \\
85\end{array}$ & $\begin{array}{l}\text { MR14 } \\
\text { MR15 } \\
\text { TRI.\#201 }\end{array}$ & $\begin{array}{l}\text { Gravity } \\
\text { Gravity } \\
\text { Gravity }\end{array}$ & $\begin{array}{l}102 \\
102\end{array}$ & $\begin{array}{l}\text { TRI.\#188 } \\
257-W L-74\end{array}$ & $\begin{array}{l}\text { Gravity } \\
\text { Magnetic } \\
\text { susceptibility }\end{array}$ \\
\hline 85 & $279-W L-76$ & Geochemical & 102 & 258-WL-74 & Density \\
\hline 86 & TRI.\#203 & Gravity & $102 \mathrm{~A}$ & 319-WL-74 & Geochemical \\
\hline 86 & $281-W L-74$ & $\begin{array}{l}\text { Density; magnetic } \\
\text { susceptibility } \\
\text { Quartz diorite }\end{array}$ & $\begin{array}{l}102 B \\
102 C \\
102 C\end{array}$ & $\begin{array}{l}320-W L-74 \\
321-W L-74 \\
322-W L-74\end{array}$ & $\begin{array}{l}\text { Office sample } \\
\text { Geochemical } \\
\text { Rack sample }\end{array}$ \\
\hline 86 & 282-WL-74 & Age date & $102 C$ & 323-WL-74 & Office sample \\
\hline 87 & TRI. 202 & Gravity & $102 \mathrm{C}$ & $324-W L-74$ & Geochemical \\
\hline 87 & $280 \cdot W L-74$ & Geochemical & $102 \mathrm{C}$ & $325-W L-74$ & Geochemical \\
\hline $\begin{array}{l}88 \\
88\end{array}$ & $\begin{array}{l}301-W L-74 \\
302-W L-74\end{array}$ & $\begin{array}{l}\text { Density } \\
\text { Geochemical }\end{array}$ & $\begin{array}{l}102 \mathrm{C} \\
102 \mathrm{D}\end{array}$ & $\begin{array}{l}326-W L-74 \\
358-W L-74\end{array}$ & $\begin{array}{l}\text { Geochemical } \\
\text { Geochemical }\end{array}$ \\
\hline 88 & 303-WL-74 & $\begin{array}{l}\text { Magnetic } \\
\text { susceptibility }\end{array}$ & $\begin{array}{l}102 \mathrm{D} \\
102 \mathrm{E}\end{array}$ & $\begin{array}{l}\text { 359-WL-74 } \\
360-W L-74\end{array}$ & $\begin{array}{l}\text { Geochemical } \\
\text { Geochemical }\end{array}$ \\
\hline 88 & DT-74-11 & Age date & $102 F$ & 361-WL-74 & Geochemical \\
\hline 89 & $304-W L-74$ & Oensity? & $102 G$ & 330-WL-74 & Geochernical \\
\hline
\end{tabular}




\begin{tabular}{|c|c|c|c|c|c|}
\hline Map No. & $\begin{array}{l}\text { Sample or } \\
\text { Station No. }\end{array}$ & $\begin{array}{l}\text { Analysis or } \\
\text { Measuremient }\end{array}$ & Map No. & $\begin{array}{l}\text { Sample or } \\
\text { Station No. }\end{array}$ & $\begin{array}{l}\text { Analysis or } \\
\text { Measurement }\end{array}$ \\
\hline $102 \mathrm{H}$ & $331-W L-74$ & Geochemical & 110 & 144-WL-74 & Geochemical \\
\hline $102 \mathrm{H}$ & 332-WL-74 & Geochemical & 111 & $60-W L \cdot 74$ & Geochemical \\
\hline $\begin{array}{l}1021 \\
1021\end{array}$ & $\begin{array}{l}\text { 350-WL-74 } \\
\text { 351-WL-74 }\end{array}$ & $\begin{array}{l}\text { Office sample } \\
\text { Magnctic } \\
\text { susccptibility }\end{array}$ & $\begin{array}{l}112 \\
112 \\
113\end{array}$ & $\begin{array}{l}60 \mathrm{~A} \cdot W \mathrm{~W}-74 \\
\text { TRI } \# 70 \\
\text { BS23 }\end{array}$ & $\begin{array}{l}\text { Geochemical } \\
\text { Gravity } \\
\text { Gravity }\end{array}$ \\
\hline $\begin{array}{l}1021 \\
1021\end{array}$ & $\begin{array}{l}352-W L-74 \\
353-W L-74\end{array}$ & $\begin{array}{l}\text { Office sample } \\
\text { Density }\end{array}$ & $\begin{array}{l}113 \\
114 \\
115\end{array}$ & $\begin{array}{l}\text { BS2S } \\
\text { BS15 } \\
\text { TRI. } 61\end{array}$ & $\begin{array}{l}\text { Graviey } \\
\text { Gravity } \\
\text { Gravily }\end{array}$ \\
\hline $\begin{array}{l}1021 \\
102 J \\
102 J \\
102 J \\
102 \mathrm{~K}\end{array}$ & $\begin{array}{l}\text { 354-WL-74 } \\
355-W L-74 \\
356-W L \cdot 74 \\
357-W L-74 \\
327-W L-74\end{array}$ & $\begin{array}{l}\text { Geochemical } \\
\text { Oftice samplc } \\
\text { Geochemical } \\
\text { Geochemical } \\
\text { Geochemical }\end{array}$ & $\begin{array}{l}116 \\
117 \\
117 \\
119 \\
120\end{array}$ & $\begin{array}{l}\text { 8S16 } \\
\text { TRI. \#68 } \\
59 \cdot W L-7 A \\
\text { TRI. } 60 \\
\text { 8S17 }\end{array}$ & $\begin{array}{l}\text { Gravity } \\
\text { Gravity } \\
\text { Gcochemical } \\
\text { Gravity } \\
\text { Gravity }\end{array}$ \\
\hline $\begin{array}{l}102 K \\
102 K \\
102 L \\
102 L \\
102 L\end{array}$ & $\begin{array}{l}\text { 328-WL-74 } \\
\text { 329-WL-74 } \\
\text { 333-WL-74 } \\
\text { 334-WL-74 } \\
\text { 335-WL-74 }\end{array}$ & $\begin{array}{l}\text { Geochemical } \\
\text { Office sample } \\
\text { Geochemical } \\
\text { Geochemical } \\
\text { Geochemical }\end{array}$ & $\begin{array}{l}121 \\
122 \\
123 \\
124 \\
124\end{array}$ & $\begin{array}{l}\text { TRI.\#59 } \\
\text { TRI.\#58 } \\
\text { TRI.\#62 } \\
\text { TRI.\#67 } \\
58-W L-74\end{array}$ & $\begin{array}{l}\text { Gravity } \\
\text { Gravity } \\
\text { Gravity } \\
\text { Gravity } \\
\text { Geochemical }\end{array}$ \\
\hline $\begin{array}{l}102 \mathrm{~L} \\
102 \mathrm{~L} \\
102 \mathrm{~L} \\
102 \mathrm{~L}\end{array}$ & $\begin{array}{l}336-W L \cdot 74 \\
337-W L-74 \\
338-W L-74 \\
339-W L-74\end{array}$ & $\begin{array}{l}\text { Age date } \\
\text { Intrusive } \\
\text { Density; magnetic } \\
\text { susceptibility } \\
\text { Geochemical }\end{array}$ & $\begin{array}{l}125 \\
126 \\
127 \\
128 \\
129\end{array}$ & $\begin{array}{l}\text { BS20 } \\
8522 \\
\text { NONE } \\
\text { TR1. \#58 } \\
\text { TRI. } \$ 56\end{array}$ & $\begin{array}{l}\text { Gravity } \\
\text { Gravity } \\
\text { NONE } \\
\text { Gravity } \\
\text { Gravity }\end{array}$ \\
\hline $\begin{array}{l}102 \mathrm{~L} \\
102 \mathrm{~L} \\
102 \mathrm{~L} \\
102 \mathrm{~L}\end{array}$ & $\begin{array}{l}340-W L-74 \\
341-W L-74 \\
342-W L-74 \\
343-W L-74\end{array}$ & $\begin{array}{l}\text { Geochemical } \\
\text { Age date } \\
\text { Density } \\
\text { Magnclic } \\
\text { susceptibility }\end{array}$ & $\begin{array}{l}130 \\
131 \\
132 \\
133 \\
134\end{array}$ & $\begin{array}{l}\text { TRI.\#55 } \\
\text { TRI.\#66 } \\
\text { TRI. } 653 \\
\text { TRI. \#19 } \\
\text { TRI. } 544\end{array}$ & $\begin{array}{l}\text { Gravity } \\
\text { Gravity } \\
\text { Gravity } \\
\text { Gravity } \\
\text { Gravity }\end{array}$ \\
\hline $\begin{array}{l}102 \mathrm{~L} \\
102 \mathrm{M}\end{array}$ & $\begin{array}{l}344-W L-74 \\
362-W L-74\end{array}$ & $\begin{array}{l}\text { Thin sections } \\
\text { Age datc }\end{array}$ & $\begin{array}{l}135 \\
136\end{array}$ & $\begin{array}{l}\text { TRI.\#47 } \\
\text { TRI.\#46 }\end{array}$ & $\begin{array}{l}\text { Gravity } \\
\text { Gravity }\end{array}$ \\
\hline $\begin{array}{l}102 \mathrm{M} \\
102 \mathrm{M} \\
102 \mathrm{M}\end{array}$ & $\begin{array}{l}\text { 363-WL-74 } \\
\text { 364-WL-74 } \\
\text { 365-WL-74 }\end{array}$ & $\begin{array}{l}\text { Geochemical } \\
\text { Density } \\
\text { Magnetic } \\
\text { susceptibility }\end{array}$ & $\begin{array}{l}137 \\
138 \\
139\end{array}$ & $\begin{array}{l}\text { TRI } 53 \\
\text { IZ24 } \\
1 \mathrm{Z} 23\end{array}$ & $\begin{array}{l}\text { Gravity } \\
\text { Gravity } \\
\text { Gravily }\end{array}$ \\
\hline $102 \mathrm{M}$ & 366-WL-74 & Geochemical & $\begin{array}{l}140 \\
141 \\
142\end{array}$ & $\begin{array}{l}S 82 \\
1 Z 21 \\
1 Z 20\end{array}$ & $\begin{array}{l}\text { Gravity (IZ22) } \\
\text { Gravity } \\
\text { Gravity }\end{array}$ \\
\hline \multicolumn{3}{|c|}{ COLD BAY QUADRANGLE (PLATE C) } & $\begin{array}{l}143 \\
144\end{array}$ & $\begin{array}{l}1219 \\
\text { TRI. \#52 }\end{array}$ & $\begin{array}{l}\text { Gravity } \\
\text { Gravity }\end{array}$ \\
\hline \multicolumn{3}{|c|}{ Random Sampling } & $\begin{array}{l}145 \\
146\end{array}$ & $\begin{array}{l}\text { IZ16 } \\
\text { IZ15 }\end{array}$ & $\begin{array}{l}\text { Gravity } \\
\text { Gravity }\end{array}$ \\
\hline $\begin{array}{l}\text { Map No. } \\
103\end{array}$ & $\begin{array}{l}\text { Sample or } \\
\text { Station No. } \\
\text { BS09 }\end{array}$ & $\begin{array}{l}\text { Analysis } \\
\text { Measurement } \\
\text { Gravily }\end{array}$ & $\begin{array}{l}147 \\
348 \\
149\end{array}$ & $\begin{array}{l}1 Z 14 \\
1 Z 17 \\
1 Z 13\end{array}$ & $\begin{array}{l}\text { Gravity } \\
\text { Gravity } \\
\text { Gravity }\end{array}$ \\
\hline $\begin{array}{l}104 \\
105 \\
106 \\
107\end{array}$ & $\begin{array}{l}\text { TRI, } \# 71 \\
\text { BS10 } \\
\text { BS11 } \\
\text { BS12 }\end{array}$ & $\begin{array}{l}\text { Gravity } \\
\text { Gravity } \\
\text { Gravity } \\
\text { Gravity }\end{array}$ & $\begin{array}{l}150 \\
151 \\
152 \\
152 \mathrm{~A}\end{array}$ & $\begin{array}{l}1 Z 18 \\
1 Z 12 \\
\text { TRI. \#65 } \\
\text { TRI. \#64 }\end{array}$ & $\begin{array}{l}\text { Gravity } \\
\text { Gravity } \\
\text { Gravity } \\
\text { Gravity }\end{array}$ \\
\hline $\begin{array}{l}108 \\
109 \\
110\end{array}$ & $\begin{array}{l}\text { BS13 } \\
\text { BS14 } \\
\text { TRI. \#124 }\end{array}$ & $\begin{array}{l}\text { Gravity } \\
\text { Gravity } \\
\text { Gravity }\end{array}$ & $\begin{array}{l}153 \\
154 \\
155\end{array}$ & $\begin{array}{l}\text { BS18 } \\
\text { BS19 } \\
42-W L-74\end{array}$ & $\begin{array}{l}\text { Gravity } \\
\text { Gravity } \\
\text { Geochemical }\end{array}$ \\
\hline
\end{tabular}




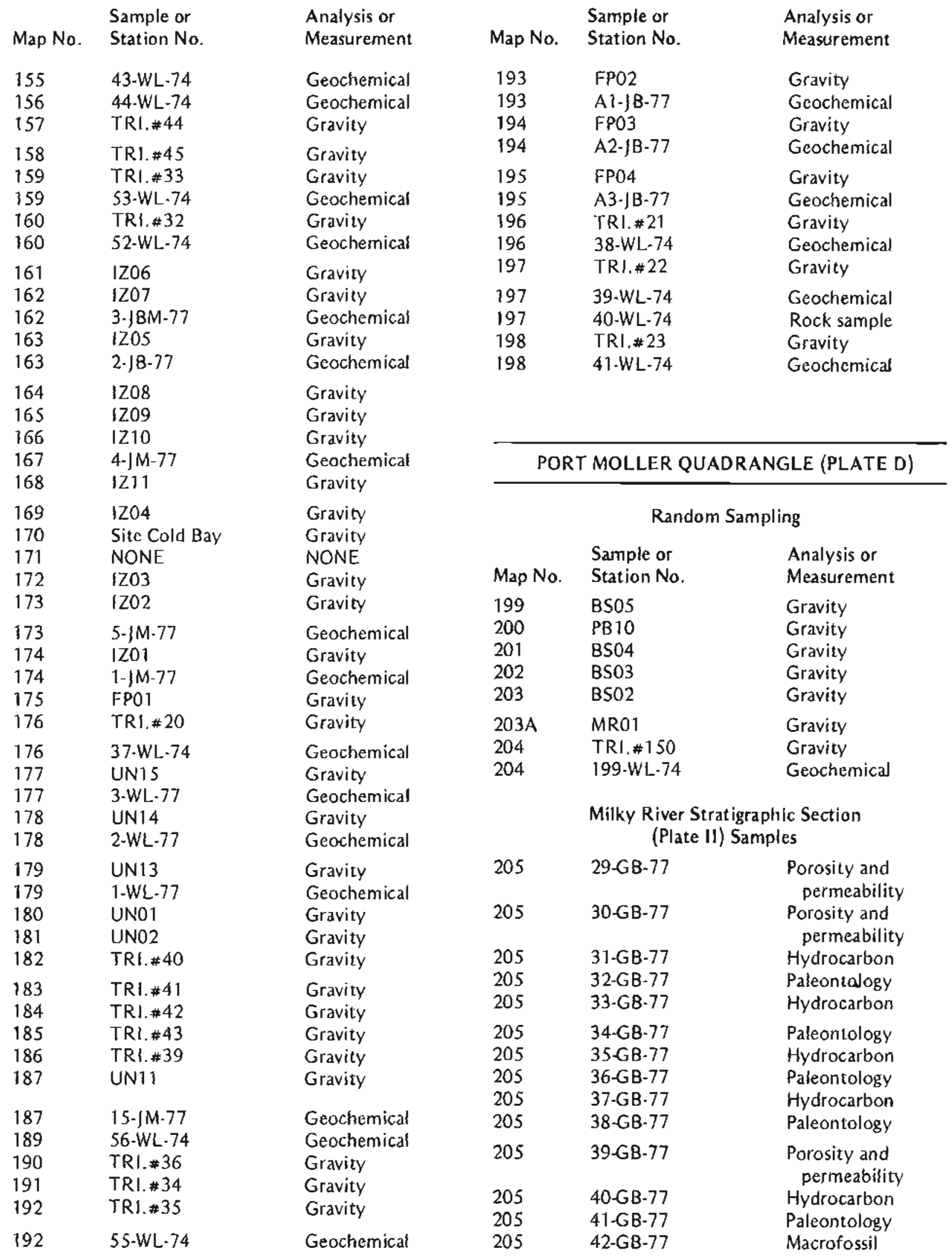




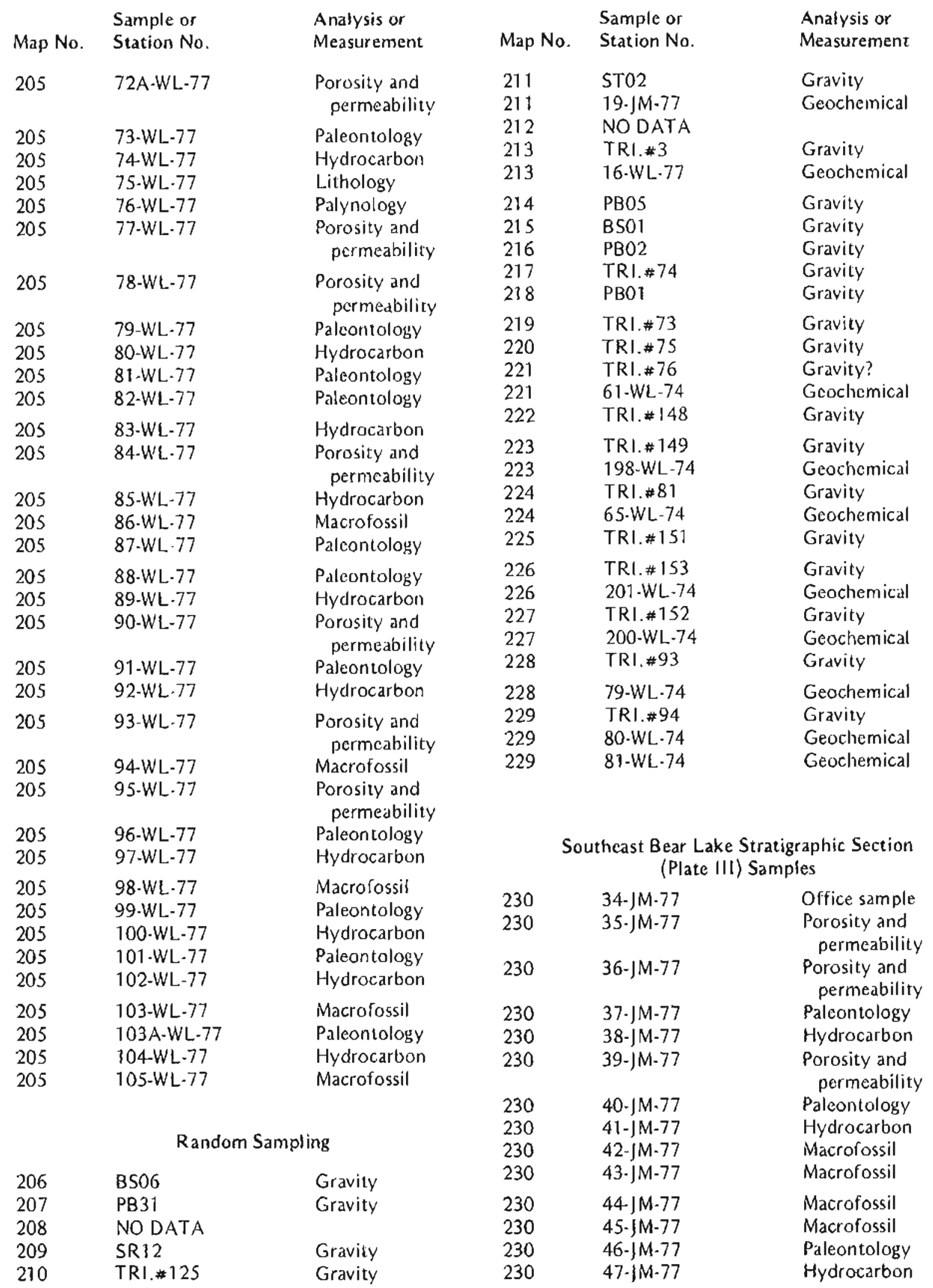




\begin{tabular}{|c|c|c|c|c|c|}
\hline Map No. & $\begin{array}{l}\text { Sample or } \\
\text { Station No. }\end{array}$ & $\begin{array}{l}\text { Analysis or } \\
\text { Measurement }\end{array}$ & Map No. & $\begin{array}{l}\text { Sample or } \\
\text { Station No. }\end{array}$ & $\begin{array}{l}\text { Analysis or } \\
\text { Measurement }\end{array}$ \\
\hline \multicolumn{3}{|c|}{ Random Sampling } & 261 & NO DATA & \multirow{5}{*}{$\begin{array}{l}\text { Gravity } \\
\text { Geochemical } \\
\text { Geochemical } \\
\text { Office sample }\end{array}$} \\
\hline 231 & TRI.\#97 & \multirow{5}{*}{$\begin{array}{l}\text { Gravity } \\
\text { Geochemical } \\
\text { Gravity } \\
\text { Geochemical } \\
\text { Gravity }\end{array}$} & 262 & $T R l . \# 175$ & \\
\hline 231 & $84 \mathrm{WL}-74$ & & 262 & 239-WL-74 & \\
\hline 232 & TRI.\#96 & & 262 & 240-WL-74 & \\
\hline 232 & 83.WL.74 & & 262 & 241.WL.74 & \\
\hline 233 & TRI.\#95 & & 262 & 242-WL-74 & Density; magnetic \\
\hline 233 & 82-WL-74 & \multirow[t]{2}{*}{ Geochemical } & 262 & 243-WL.74 & $\begin{array}{l}\text { susceptibility } \\
\text { office samole }\end{array}$ \\
\hline 234 & NO DATA & & 263 & TRI.\#176 & $\begin{array}{l}\text { Gravity } \\
\text { Grample }\end{array}$ \\
\hline 235 & PB30 & \multirow{3}{*}{$\begin{array}{l}\text { Gravity } \\
\text { Gravity } \\
\text { Gravily }\end{array}$} & 263 & 244-WL-74 & Geochemical \\
\hline 236 & $\mathrm{BSO7}$ & & 264 & TRI. \#160 & Gravity \\
\hline 237 & TRI. 72 & & 265 & TRI.\#177 & \multirow{6}{*}{$\begin{array}{l}\text { Gravity } \\
\text { Geochemical } \\
\text { Density } \\
\text { Magnetic } \\
\text { susceptibility } \\
\text { Office sample }\end{array}$} \\
\hline $237 \mathrm{~A}$ & TRI.\#126 & \multirow{5}{*}{$\begin{array}{l}\text { Gravity } \\
\text { Gravity } \\
\text { Gravity } \\
\text { Geochemical } \\
\text { Gravity }\end{array}$} & 265 & $245 \cdot$ WL -74 & \\
\hline 238 & SR13 & & 265 & 246-WL-74 & \\
\hline 239 & SR 11 & & \multirow[t]{2}{*}{265} & \multirow[t]{2}{*}{$247 \cdot$ WL-74 } & \\
\hline 239 & $30-1 \mathrm{M}-77$ & & & & \\
\hline 240 & SR 10 & & 265 & 248-WL-74 & \\
\hline 240 & $29-1 M-77$ & \multirow{5}{*}{$\begin{array}{l}\text { Geochemical } \\
\text { Gravity } \\
\text { Gravity } \\
\text { Gcochemical } \\
\text { Gravity }\end{array}$} & 266 & TRI.\#157 & \multirow{6}{*}{$\begin{array}{l}\text { Gravity } \\
\text { Geochemical } \\
\text { Office sample } \\
\text { Gravity? } \\
\text { Porosity and } \\
\text { permeability }\end{array}$} \\
\hline 241 & PB11 & & 266 & $212-W L-74$ & \\
\hline 242 & SRO3 & & 266 & 142-WL-74 & \\
\hline 242 & $20-1 \mathrm{M} \cdot 77$ & & 267 & TRI. $\# 133$ & \\
\hline 243 & SROI & & 267 & 153-WL-77 & \\
\hline 243 & $18-1 \mathrm{M}-77$ & \multirow{6}{*}{$\begin{array}{l}\text { Geochemical } \\
\text { Gravity } \\
\text { Geochemical } \\
\text { Gravity } \\
\text { Gravity }\end{array}$} & & & \\
\hline 244 & SR04 & & 267 & 154.WL-77 & Density \\
\hline 244 & $21-1 M-77$ & & 267 & 155-WL-77 & Office sample \\
\hline 245 & TRI.\#127 & & 267 & 156-WL.77 & Volcanic flow \\
\hline 246 & PB06 & & 268 & NO DATA & \\
\hline 247 & P807 & & 269 & 62-WL-74 & Macrofossil \\
\hline 248 & PBO9 & \multirow{4}{*}{$\begin{array}{l}\text { Gravity } \\
\text { Gravity } \\
\text { Gravity } \\
\text { Gravity } \\
\text { Gravity }\end{array}$} & 270 & $T R I . \# 84$ & \multirow{5}{*}{$\begin{array}{l}\text { Gravity } \\
\text { Geochemical } \\
\text { Office sample } \\
\text { Gravity } \\
\text { Geochemical }\end{array}$} \\
\hline 249 & PB08 & & 270 & $69 \cdot W L-74$ & \\
\hline 250 & PBO4 & & 271 & $66-W L-74$ & \\
\hline 251 & TRI. 138 & & 272 & TRI.\#85 & \\
\hline 251 & 162-WL-74 & \multirow{3}{*}{$\begin{array}{l}\text { Geochemical } \\
\text { Geochemical }\end{array}$} & & 70-WL-74 & \\
\hline 251 & 163-WL-74 & & 272 & TRI.\#79 & \multirow{4}{*}{$\begin{array}{l}\text { Gravity } \\
\text { Geochemical } \\
\text { Gravity } \\
\text { Geochemical } \\
\text { Gravity }\end{array}$} \\
\hline 252 & NO DATA & & 272 & 63-WL-74 & \\
\hline 253 & PBO3 & \multirow{2}{*}{$\begin{array}{l}\text { Gravity } \\
\text { Gravity }\end{array}$} & 273 & TRI $\# 89$ & \\
\hline 254 & TRI. 173 & & $\begin{array}{l}273 \\
274\end{array}$ & $\begin{array}{l}75-W L-74 \\
\text { TRL } 91\end{array}$ & \\
\hline 254 & 237-WL-74 & Geochemical & 275 & TRI. $\$ 0$ & Gravity \\
\hline 255 & 160-WL-74 & Rock sample & 275 & $76-W L-74$ & Geochernical \\
\hline 255 & 161-WL-74 & Geochemical & 275 & $77-W L-74$ & Macrofossil \\
\hline 256 & 158-WL-76 & Geochemical & 276 & TRI.\#86 & Gravity \\
\hline \multirow[t]{2}{*}{256} & \multirow[t]{2}{*}{ 159-WL-74 } & \multirow{2}{*}{$\begin{array}{l}\text { Density; magnetic } \\
\text { susceptibility }\end{array}$} & 276 & $71-W L-74$ & Geochemical \\
\hline & & & 277 & TRI.\#88 & Gravity \\
\hline 257 & $73-G B-77$ & Porosity and & 277 & $74 W L-74$ & Geochemical \\
\hline & & permeability & 278 & TRI.\#87 & Gravity \\
\hline 258 & $74-\mathrm{GB}-77$ & Paleontology & 278 & 72.WL-74 & Geochemical \\
\hline 259 & TRI. 134 & Gravity & 279 & TRI. \#80 & Gravity \\
\hline 259 & 157-WL-74 & Geochemical & & & \\
\hline 260 & 143-WL-74 & Geochemical & 280 & TRI.\#83 & Gravity \\
\hline
\end{tabular}


Sample or

Map No. Station No.

$\begin{array}{ll}280 & 67-W L-74 \\ 280 & 68-W L-74 \\ 281 & \text { TRI.\#92 } \\ 281 & 78-W L-74 \\ 282 & \text { TRI.\#152 } \\ 282 & 202-W L-74 \\ 282 & 203-W L-74 \\ 283 & \text { TRI.\#155 } \\ 283 & 204-W L-74 \\ 283 & 205-W L-74 \\ 283 & 206-W L-74 \\ & \\ 283 & 207-W L-74 \\ 283 & 208-W L-74 \\ 283 & 209-W L-74 \\ 283 & 210-W L-74 \\ 284 & \text { BS08 } \\ 285 & \text { PB29 } \\ 286 & \text { 8S24 } \\ 287 & \text { SRT4 } \\ 287 & 31-J M-77 \\ 288 & \text { SR09 } \\ 288 & 28-J M-77 \\ 289 & \text { PB12 } \\ 290 & \text { SR07 } \\ 290 & 25-J M-77 \\ 290 & 26-J M-77\end{array}$

Analysis or Measurement

Geochemical

Geochemical

Gravity

Geochemical

Gravily

Gcochemical

Geochemical

Gravily

Geochemical

Geochemical

Density; magnetic susceptibility

Orfice sample

Density

Density

Ofrice sample

Gravity

Gravity

Gravily

Gravity

Geochemical

Gravily

Geochemical

Gravity

Gravity

Geochemical

Geochemical

Heren I and II Stratigraphic Sections

(Plares IV and V) Samples

$\begin{array}{ll}291 & 26-1 P-77 \\ 291 & 27-1 P-77 \\ 291 & 28-1 P-77 \\ & \\ 291 & 29-1 P-77 \\ 291 & 30-1 P-77 \\ 291 & 31-1 P-77 \\ & \\ 291 & 32-1 P-77 \\ & \\ 291 & 33-1 P-77 \\ 291 & 34-1 P-77 \\ & \\ 291 & 35-1 P-77 \\ & \\ 291 & 36-1 P-77 \\ 291 & 37-1 P-77 \\ 291 & 38-1 P-77\end{array}$

$\begin{array}{ll}\text { Paleontology } & 295 \\ \text { Palcontology } & 295 \\ \text { Porosity and } & 295 \\ \text { pcrmeability } & 296 \\ \text { Paleontology } & 296 \\ \text { Coal } & 296 \\ \text { Porosity and } & 297 \\ \text { permeability } & \\ \text { Porosity and } & 297 \\ \text { permeability } & \\ \text { Palcontology } & 297 \\ \text { Porosity and } & \\ \text { pcrmeability } & 297 \\ \text { Porosity and } & \\ \text { pcrmeability } & 297 \\ \text { Palcontology } & \\ \text { Hydrocarbon } & 297 \\ \text { Porosity and } & 298 \\ \text { permeability } & 299\end{array}$

Sample or

291

291

291

291

291

291

291

291

291

291

291

291

291

291

291

$53-1 P-77$

47-IP-77

48.1P. 77

49-1P.77

50-IP-77

$51 \cdot 1 \mathrm{P} \cdot 77$

$52 \cdot 19.77$

41-19.77

42.19 .77

$441 \mathrm{P}-77$

45.1P.77

46-1P.77

7

7

39. $1 \mathrm{P}-77$

Analysis or

Measurement

Porosity and permeability

Palcontology

Palcontology

Hydrocarbon

Porosily and permeability

Palcontology

Hydrocarban

Porosily and permcability

Palcontology

Coal

Palcontology

Hydrocarbon

Porosity and permcability

Porosily and permcability

Porosity and permeability

\section{Random Sampling}

292

293

294

294

294

95

95

96

96

96

7

97

97

60-GB.77

61-GB-77

62.GB-77

63-GB-77

28.WL.74

29.WL-74
Geochemical

Geochemical

Porosity and permeability

Lithology

Porosily and pcrmcability

Gravity

Age date

Age dale

Gravity

Gravity

Geochemical

Porosity and permeability

Porosity and permcabilicy

Porisity and permeability

Porosity and permeability

Porosity and permeability

Hydrocarbon

Geochemical

Geochemical 


\begin{tabular}{|c|c|c|c|c|c|}
\hline Map No. & $\begin{array}{l}\text { Sample or } \\
\text { Station No. }\end{array}$ & $\begin{array}{l}\text { Analysis or } \\
\text { Measurement }\end{array}$ & Map No. & $\begin{array}{l}\text { Sample or } \\
\text { Station No. }\end{array}$ & $\begin{array}{l}\text { Analysis or } \\
\text { Measurement }\end{array}$ \\
\hline 300 & 164-WL-74 & Geochemical & & \multirow{2}{*}{\multicolumn{2}{|c|}{$\begin{array}{l}\text { Waterfall Pt. Stratigraphic Section } \\
\text { (Plate VI) Samples }\end{array}$}} \\
\hline 300 & $165 \cdot W L-74$ & Geochemical & & & \\
\hline $\begin{array}{l}301 \\
301\end{array}$ & $\begin{array}{l}\text { TRI. \#174 } \\
238-W L-74\end{array}$ & $\begin{array}{l}\text { Gravity } \\
\text { Geochemical }\end{array}$ & 322 & 1.GB-77 & $\begin{array}{l}\text { Porosity and } \\
\text { permcability }\end{array}$ \\
\hline $\begin{array}{l}302 \\
302\end{array}$ & $\begin{array}{l}\text { TRI.\#140 } \\
166-W L \cdot 74\end{array}$ & $\begin{array}{l}\text { Gravity } \\
\text { Geochemical }\end{array}$ & 322 & 2-G8-77 & Lithology \\
\hline $\begin{array}{l}303 \\
303\end{array}$ & $\begin{array}{l}\text { TRI. } \# 166 \\
255-W L-74\end{array}$ & $\begin{array}{l}\text { Gravity } \\
\text { Porosity and } \\
\text { permeability }\end{array}$ & $\begin{array}{l}322 \\
322\end{array}$ & $\begin{array}{l}3-\mathrm{GB}-77 \\
4 \mathrm{~GB}-77\end{array}$ & $\begin{array}{l}\text { Paleontology } \\
\text { Porosity and } \\
\text { permeability } \\
\text { Paleontology }\end{array}$ \\
\hline $\begin{array}{l}303 \\
303 \\
304\end{array}$ & $\begin{array}{l}226 \cdot \text { WL-74 } \\
\text { 227-WL-74 } \\
\text { TRI. } 141\end{array}$ & $\begin{array}{l}\text { Density } \\
\text { Office sample } \\
\text { Gravity }\end{array}$ & $\begin{array}{l}322 \\
322 \\
322\end{array}$ & $\begin{array}{l}\text { 6-GB-77 } \\
\text { 7-GB-77 } \\
8-G B-77\end{array}$ & $\begin{array}{l}\text { Hydrocarbon } \\
\text { Paleontology } \\
\text { Lithology }\end{array}$ \\
\hline $\begin{array}{l}304 \\
305 \\
306\end{array}$ & $\begin{array}{l}\text { 167-WL-74 } \\
219-W L-74 \\
216-W L-74\end{array}$ & $\begin{array}{l}\text { Geochemical } \\
\text { Office sample } \\
\text { Geochemical }\end{array}$ & 322 & $10-6 \mathrm{~B}-77$ & $\begin{array}{l}\text { Porosity and } \\
\text { permeability } \\
\text { Hydrocarbon }\end{array}$ \\
\hline 306 & $217-W L-74$ & Age dale & 322 & $11-G B-77$ & Paleontology \\
\hline 306 & $218-W L-74$ & $\begin{array}{l}\text { Magnetic } \\
\text { susceptibility }\end{array}$ & $\begin{array}{l}322 \\
322\end{array}$ & $\begin{array}{l}\text { I2-GB-77 } \\
13-G B-77\end{array}$ & $\begin{array}{l}\text { Macrofossil } \\
\text { Porosity and }\end{array}$ \\
\hline $\begin{array}{l}307 \\
307\end{array}$ & $\begin{array}{l}\text { TRI, \#158 } \\
213-W L-74\end{array}$ & $\begin{array}{l}\text { Gravity } \\
\text { Age date }\end{array}$ & 322 & $14 \mathrm{~GB}-77$ & $\begin{array}{l}\text { permeability } \\
\text { Hydrocarbon }\end{array}$ \\
\hline 307 & 214-WL-74 & Geochemical & 322 & $15-\mathrm{GB} \cdot 77$ & Paleantology \\
\hline 307 & $215-W L-74$ & $\begin{array}{l}\text { Density; magnetic } \\
\text { susceptibility }\end{array}$ & & & \\
\hline 308 & $T R I . \# 102$ & Gravity & & \multicolumn{2}{|c|}{ Random Sampling } \\
\hline $\begin{array}{l}308 \\
309 \\
310 \\
311 \\
311\end{array}$ & $\begin{array}{l}\text { 115-WL-74 } \\
141-W L-74 \\
138-W L-74 \\
\text { TRI.\#146 } \\
\text { 194-WL-74 }\end{array}$ & $\begin{array}{l}\text { Geochemical } \\
\text { Geochemical } \\
\text { Geochemical } \\
\text { Gravity } \\
\text { Rock sample }\end{array}$ & $\begin{array}{l}323 \\
324 \\
324 \\
325 \\
325\end{array}$ & $\begin{array}{l}\text { PB28 } \\
\text { SR16 } \\
33 \cdot \mid M-77 \\
\text { SR15 } \\
\text { 32-IM-77 }\end{array}$ & $\begin{array}{l}\text { Gravity } \\
\text { Gravity } \\
\text { Geochemical } \\
\text { Gravity } \\
\text { Geochemical }\end{array}$ \\
\hline $\begin{array}{l}311 \\
312 \\
312 \\
313 \\
314\end{array}$ & $\begin{array}{l}\text { 195-WL-74 } \\
139-W L-74 \\
140-W L-74 \\
151-W L-74 \\
149-W L-74\end{array}$ & $\begin{array}{l}\text { Burned } \\
\text { Geochemical } \\
\text { Geochemical } \\
\text { Geochemical } \\
\text { Geochemical }\end{array}$ & $\begin{array}{l}326 \\
327 \\
328 \\
329 \\
329\end{array}$ & $\begin{array}{l}\text { PB15 } \\
\text { TRI. } 30 \\
\text { PB14 } \\
\text { SR08 } \\
27-J M-77\end{array}$ & $\begin{array}{l}\text { Gravity } \\
\text { Gravity } \\
\text { Gravity } \\
\text { Geochemical }\end{array}$ \\
\hline $\begin{array}{l}315 \\
315 \\
316 \\
316\end{array}$ & $\begin{array}{l}\text { TRI. } \# 130 \\
148-W L-74 \\
\text { TRI.\#129 } \\
146 \cdot W L-74\end{array}$ & $\begin{array}{l}\text { Density } \\
\text { Geochemical } \\
\text { Gravity } \\
\text { Density; magnetic } \\
\text { susceptibility }\end{array}$ & $\begin{array}{l}330 \\
330 \\
331 \\
331 \\
332\end{array}$ & $\begin{array}{l}\text { SRO6 } \\
23-J M-77 \\
\text { SROS } \\
22-1 M-77 \\
155 \cdot \text { JM-77 }\end{array}$ & $\begin{array}{l}\text { Gravity } \\
\text { Geochemical } \\
\text { Gravity } \\
\text { Geochemical } \\
\text { Geochemical }\end{array}$ \\
\hline 310 & $14 /-W 2-14$ & Geocnemical & 333 & $156-j \mathrm{MB}-77$ & Geochemical \\
\hline 317 & TRI. $\# 103$ & Gravity & 333 & $156-\{8-77$ & Geochemical \\
\hline 318 & TRI.\#128 & Gravity & 334 & $153-\} 8.77$ & Geochemical \\
\hline 318 & 145-WL-74 & Geochemical & 335 & $154-18-77$ & Geochemical \\
\hline 319 & 116-WL-74 & Geochemical & $335 \mathrm{~A}$ & 22-WL-74 & Age date \\
\hline 320 & TRI.\#1S6 & Gravity & $335 \mathrm{~A}$ & 23-WL-74 & Age date \\
\hline 320 & 211 -WL-74 & Geochemical & $335 \mathrm{~A}$ & 24.WL-74 & Hydrocarbon \\
\hline 321 & 77-SWH-11 & $\begin{array}{l}\text { Density; magnetic } \\
\text { susceptibility }\end{array}$ & $\begin{array}{l}335 A \\
336\end{array}$ & $\begin{array}{l}\text { 25-WL-74 } \\
133 \mathrm{~A}-W L-74\end{array}$ & $\begin{array}{l}\text { Rock sample } \\
\text { Geochemical }\end{array}$ \\
\hline 321 & $77-S W H-12$ & Paleontology & 336 & 133B-WL-74 & Geochemical \\
\hline
\end{tabular}




\begin{tabular}{|c|c|c|c|c|c|}
\hline Map No. & $\begin{array}{l}\text { Sample or } \\
\text { Station No. }\end{array}$ & $\begin{array}{l}\text { Analysis or } \\
\text { Measurement }\end{array}$ & Map No. & $\begin{array}{l}\text { Sample or } \\
\text { Station No. }\end{array}$ & $\begin{array}{l}\text { Analysis or } \\
\text { Measurement }\end{array}$ \\
\hline 337 & TRI.\# I 14 & Gravity & 353 & 124-W'L-74 & Density \\
\hline 337 & $132 \cdot W L-74$ & Geochemical & 353 & $125-X^{\prime} L-74$ & Magnetic \\
\hline 338 & TRI.\# 711 & Gravity & & & susceptibility \\
\hline 338 & 127.WL-74 & Geochemical & 354 & TRI.\$106 & Gravity \\
\hline 339 & TRI.\#112 & Gravity & 354 & 119.W'L.74 & Geochemical \\
\hline 339 & 128-WL-74 & Geochemical & 355 & $33 . W 1 .-74$ & Agc datc \\
\hline 340 & $75-G B-77$ & Paleontology & $355 \mathrm{~A}$ & $18-$ WL. .74 & Agc clate \\
\hline 340 & 76-GB-77 & Hydrocarbon & 356 & TRI.非 101 & Gravity \\
\hline 340 & 77-GB-77 & Paleontology & 356 & $114-W / L-74$ & Geochemical \\
\hline 340 & $78-\mathrm{GB}-77$ & Hydrocarbon & 357 & TRI. & Gravity \\
\hline 340 & $79-\mathrm{GB}-77$ & Palcontology & 357 & 224-W/L-74 & Geochemical \\
\hline 340 & $80 \cdot G B \cdot 77$ & Hydrocarhon & 358 & TRI.\$162 & Gravity \\
\hline 340 & $81-G B .77$ & Páleontology & 358 & $220 \cdot W L-74$ & Geochemical \\
\hline 340 & $82 G B-77$ & Hydrocarbon & 359 & TRI ، 163 & Gravity \\
\hline 340 & $83-G B-77$ & Palcontology & 359 & $221 \cdot W L-74$ & Gcochemical \\
\hline 340 & $84-G B \cdot 77$ & Hydrocarbon & 360 & TRI. $\$ 164$ & Gravity \\
\hline 340 & $85-G B \cdot 77$ & Paleontology & 360 & 222-W/L-74 & Geochemical \\
\hline 340 & $86 \cdot \mathrm{GB}-77$ & Hydrocarbon & 360 & 223-WIL-74 & Geochemical \\
\hline 340 & $87-\mathrm{GB} \cdot 77$ & Paleontology & 361 & TRJ.\$: 167 & Gravity \\
\hline 340 & $88 \cdot G B \cdot 77$ & Hydrocarbon & 361 & 228-W/L-74 & Geochemical \\
\hline 340 & $89-G B-77$ & Paleontology & 362 & P827 & Gravity \\
\hline 340 & $90-\mathrm{GB}-77$ & Hydrocarbon & 363 & PB16 & Gravily \\
\hline 341 & TRI.\#113 & Gravity & 364 & TRI. $: 26$ & Gravity \\
\hline 341 & 130-WL-74 & Geochemical & 364 & $45 \cdot$ WI.-74 & Geochemical \\
\hline 341 & 131-WL-74 & Geochemical & 365 & PB13 & Gravity \\
\hline 342 & TRI \# 145 & Gravity? & 365 & TRI. $¥ 9$ & Gravity \\
\hline 342 & 192.WL-74 & Age date & 365 & $21-W I_{-}-74$ & Gcochemical \\
\hline 342 & 193-WL-74 & Burned & 366 & 150.JB-77 & Geochemical \\
\hline 343 & TRI.\#116 & Gravity & 367 & TRI. \# 142 & Gravity \\
\hline 343 & 134-WL-74 & Geochemical & 367 & 168-W/L.74 & Geochemical \\
\hline 344 & $T R I \# 1: 0$ & Gravity & 368 & $152 \cdot \mid \mathrm{B}-77$ & Geochemical \\
\hline 344 & 126-WL-74 & Geochemical & & & \\
\hline 345 & $30-W L-74$ & Geochemical & \multirow{3}{*}{\multicolumn{3}{|c|}{$\begin{array}{l}\text { Lefthand Bay-Balboa Bay Stratigraphic Section } \\
\text { (Plate VII) Samples }\end{array}$}} \\
\hline 346 & TR1.\#117 & Gravity & & & \\
\hline 346 & 135-WL-74 & Geochemical & & & \\
\hline 347 & TRI. 7 & Gravily & 369 & $16-G(3-77$ & Hydrocarbon \\
\hline 347 & 19-WL-74 & Density & 369 & $17-G 8-77$ & Palcontology \\
\hline 348 & 136-WL-74 & Geochemical & 369 & $18-G[3-77$ & Hydrocarbon \\
\hline 348 & 137-WL-74 & Geochemical & 369 & 18-GB-77 & Hydrocarbon \\
\hline 349 & 31-WL-74 & Geochemical & 369 & $19 \cdot \mathrm{GB}-77$ & Paleontology \\
\hline 349 & 32-WL-74 & Geochemical & 369 & $20-G B-77$ & Lithology \\
\hline 350 & 34WL-74 & Gcochemical & 369 & $21-G_{3} 3-77$ & Hydrocarbon \\
\hline 350 & 35-WL.74 & Geochemica! & 369 & $22-\mathrm{G} B 3-77$ & Paleontology \\
\hline 350 & $36-W L-74$ & Geochcmical & 369 & $23-\mathrm{GB}-77$ & Lithology \\
\hline 351 & TRI.\# 307 & Gravity & 369 & $24-G 83-77$ & Hydrocarbon \\
\hline 351 & 120.WL-74 & Geochemical & 369 & $25 \cdot G\{3-77$ & Paleontology \\
\hline 351 & 121 -WL- 74 & Geochemical & 369 & $26-\mathrm{GB} 3.77$ & Hydrocarbon \\
\hline 352 & TRI \#108 & Gravity & 369 & $27-\mathrm{GB} 3-77$ & Paleontology \\
\hline 352 & 122-WL-74 & Rock sample & 369 & 28-GB-77 & Lithology \\
\hline 353 & 123.WL-74 & Lithology & 369 & $9-1 P-77$ & Paleontology \\
\hline
\end{tabular}




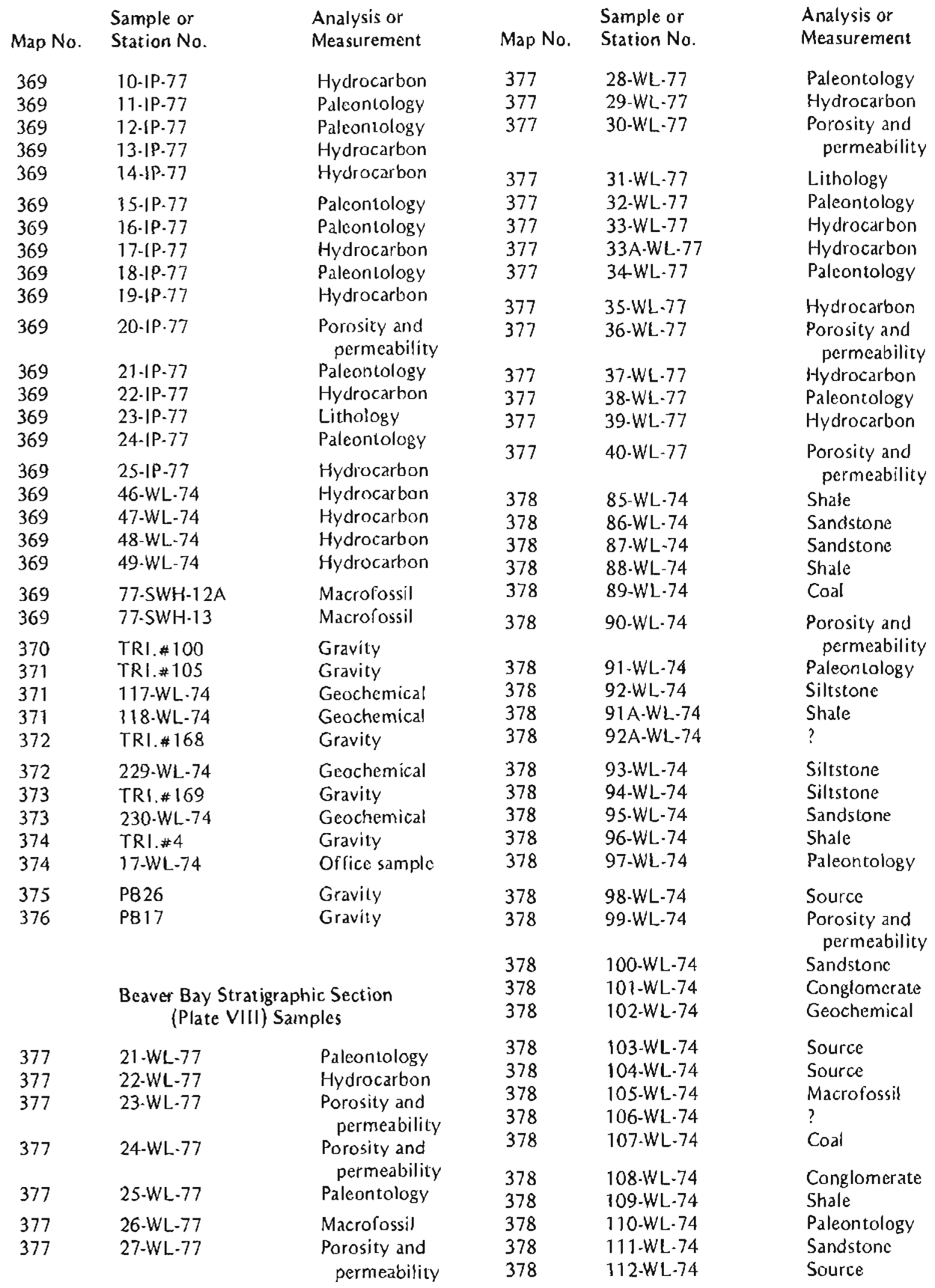




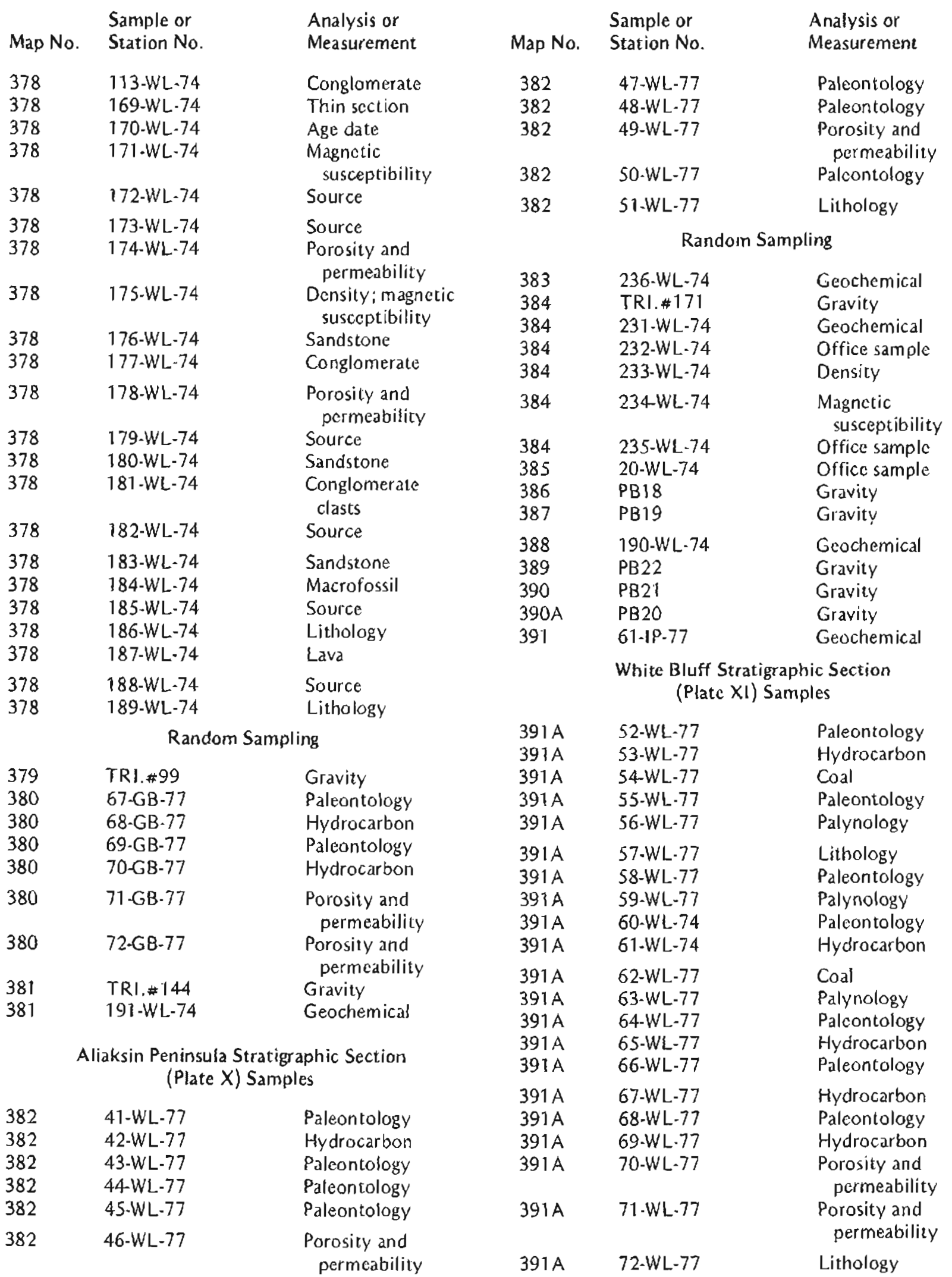




\begin{tabular}{|c|c|c|c|c|c|}
\hline Map No. & $\begin{array}{l}\text { Sample or } \\
\text { Station No. }\end{array}$ & $\begin{array}{l}\text { Analysis or } \\
\text { Measurement }\end{array}$ & Map No. & $\begin{array}{l}\text { Sample or } \\
\text { Station No. }\end{array}$ & $\begin{array}{l}\text { Analysis or } \\
\text { Measurement }\end{array}$ \\
\hline & \multirow{2}{*}{\multicolumn{2}{|c|}{ Random Sampling }} & 416 & 16. $\mathrm{M}-77$ & Geochemical \\
\hline & & & 417 & $24 \cdot 18-77$ & Geochemical \\
\hline 392 & PB24 & Gravity & 418 & FPí1 & Gravicy \\
\hline 393 & PB23 & Gravity & 419 & FP10 & Gravity \\
\hline 394 & $60-1 P-77$ & Geochemical & 420 & FPOS & Gravity \\
\hline $\begin{array}{l}395 \\
396\end{array}$ & $\begin{array}{l}59-1 P-77 \\
58-1 P-77\end{array}$ & $\begin{array}{l}\text { Geochemical } \\
\text { Geochemical }\end{array}$ & \multirow{2}{*}{$\begin{array}{l}420 \\
420\end{array}$} & \multirow{2}{*}{$\begin{array}{l}\text { A } 7 . \mathrm{JB}^{\mathrm{B}-77} \\
77-\mathrm{SWH}-01\end{array}$} & \multirow{2}{*}{$\begin{array}{l}\text { Geochemical } \\
\text { Oriented basalt }\end{array}$} \\
\hline 397 & $57.1 P \cdot 77$ & Geochemical & & & \\
\hline 398 & $54-19-77$ & Geochemical & \multirow{3}{*}{\multicolumn{3}{|c|}{$\begin{array}{l}\text { East Morzhovoi Bay Stratigraphic Section } \\
\qquad(\text { Plate XII) Samples }\end{array}$}} \\
\hline 399 & $56-1 P-77$ & Geochemical & & & \\
\hline 400 & PB25 & Gravity & & & \\
\hline 401 & $55-1 P-77$ & Geochemical & 421 & $43-G B-77$ & Hydrocarbon \\
\hline & & & 421 & 44-GB-77 & Paleontology \\
\hline \multicolumn{3}{|c|}{ STEPOVAK QUADRANGLE (PLATE E) } & 421 & $45-\mathrm{GB} \cdot 77$ & Hydrocarbon \\
\hline \multicolumn{3}{|c|}{ Random Sampling } & $\begin{array}{l}421 \\
421\end{array}$ & $\begin{array}{l}46-G B-77 \\
47-G B-77\end{array}$ & $\begin{array}{l}\text { Paleontology } \\
\text { Macrofossil }\end{array}$ \\
\hline & & & 421 & $48-G B-77$ & Hydrocarbon \\
\hline & Sample or & Analysis or & 421 & $49-G B-77$ & Palcontology \\
\hline Map No. & Station No. & Measurement & 421 & $50.18 \cdot 77$ & Palcontology \\
\hline & & & 421 & 51.GB-77 & Macrofossil \\
\hline 402 & $55-3 \mathrm{M}-77$ & Geochemical & 421 & $52-G B-77$ & Porosity and \\
\hline 402 & $56 \cdot 1 \mathrm{M} \cdot 77$ & Geochemical & & & permeability \\
\hline $\begin{array}{l}403 \\
403\end{array}$ & $\begin{array}{l}53-J M-77 \\
54-1 M-77\end{array}$ & $\begin{array}{l}\text { Geochemical } \\
\text { Gcochemical }\end{array}$ & 421 & $53-G B-77$ & Macrofossil \\
\hline 404 & $104-18-77$ & Geochemical & 421 & $54-G B-77$ & Lithology \\
\hline 405 & $105-J B-77$ & Geochemical & 421 & 55-GB.77 & Macrofossil \\
\hline 406 & $102 \cdot \mathrm{B}-77$ & Geochemical & 421 & $56 \cdot G B-77$ & Porosity and \\
\hline 407 & 101.JB-77 & Geochemical & 421 & $57 \mathrm{~GB}-77$ & Lithology \\
\hline 408 & 99-)B-77 & Geochemica! & 421 & 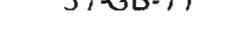 & \\
\hline 409 & $100 \cdot 1 \mathrm{~B}-77$ & Geochemical & & \multicolumn{2}{|c|}{ Random Sampling } \\
\hline 410 & $48-J \mathrm{~B}-77$ & Geochemical & & FP08 & \\
\hline 410 & 49.JB-77 & Geochemical & $\begin{array}{l}421 \mathrm{~A} \\
422\end{array}$ & $6 \cdot 1 \mathrm{~B}-77$ & Gravity \\
\hline 410 & $50-j \mathrm{M}-77$ & Geochemical & 422 & $\begin{array}{l}0.10-17 \\
7-18.77\end{array}$ & Gcochemical \\
\hline 410 & 51.JM-77 & Lithology & $\begin{array}{l}422 \\
422\end{array}$ & $\begin{array}{l}7-16-17 \\
9.18-77\end{array}$ & Geochemical \\
\hline 410 & $52 \cdot 3 \mathrm{M}-77$ & Geochemical & $\begin{array}{l}422 \\
422\end{array}$ & 77-SWH-1A & Geochemical \\
\hline 411 & $98 \cdot \mathrm{J} 8.77$ & Geochemical & & & Geochemical \\
\hline 412 & $106-\int B-77$ & Geochemical & 422 & 77-SWH-2A & Geochemical \\
\hline 413 & 102-jB-77 & Geochemical & 422 & 77-SWH-3A & Geochemical \\
\hline & & & 422 & 77.SWH-4A & Geochemical \\
\hline \multicolumn{3}{|c|}{ FALSE PASS QUADRANGLE (PLATE F) } & 423 & EP07 & $\begin{array}{l}\text { Gcochemical } \\
\text { Gravity }\end{array}$ \\
\hline \multicolumn{3}{|c|}{ Random Sampling } & $\begin{array}{l}423 \\
424\end{array}$ & $\begin{array}{l}\text { A6- } 1 B-77 \\
\text { FP06 }\end{array}$ & $\begin{array}{l}\text { Geochemical } \\
\text { Gravity }\end{array}$ \\
\hline & & & 424 & A5-jB-77 & Geochemical \\
\hline & Sample or & Andlysis or & 424 & 77.SWH-01B & Bulk rock \\
\hline Map No. & Station No. & Measurement & 424 & 77.SWH-O2 & Bulk rock \\
\hline 414 & UN03 & Gravity & 424 & 77-SWH-03 & Bulk rock \\
\hline 414 & $7-J M-77$ & Gcochemical & 424 & 77-SWH-04 & Bulk rock \\
\hline 415 & UN10 & Gravity & 424 & 77.SWH.05 & Bulk rock \\
\hline 416 & UN12 & Gravity & 424 & 77-SWH-06 & Bulk rock \\
\hline 416 & $25-J B-77$ & Geochemical & 424 & 77.SWH.07 & Bulk rock \\
\hline
\end{tabular}




$\begin{array}{ll}\text { Map No. } & \begin{array}{l}\text { Sample or } \\ \text { Station No. }\end{array} \\ 424 & 77-5 W H-08 \\ 425 & \text { FPOS } \\ 425 & \text { A4.JB-77 } \\ 426 & \text { UNO4 } \\ 426 & 8-J M-77 \\ 427 & \text { FP19 } \\ 427 & 9 \cdot 3 \text { M- } 77 \\ 428 & \text { FP19 } \\ 428 & \text { A10-JB-77 } \\ 429 & \text { FP18 } \\ 430 & \text { FP20 }\end{array}$

Analysis or
Measurement
Bulk rock
Gravity
Geochemical
Gravity
Geochemical
Gravity
Geochemical
Gravity
Geochemical
Gravity
Gravity

West Morzhovoi Bay Stratigraphic Section

(P\{ate XIII) Samples

\begin{tabular}{|c|c|c|}
\hline 431 & $1-1 P-77$ & $\begin{array}{l}\text { Porosity and } \\
\text { permeability }\end{array}$ \\
\hline 431 & $2-1 P-77$ & $\begin{array}{l}\text { Porosily and } \\
\text { permeability }\end{array}$ \\
\hline 431 & $3-\{P-77$ & Paleontology \\
\hline 431 & $4-1 P-77$ & Macrofossil \\
\hline 431 & $5.1 P .77$ & Paleontology \\
\hline 431 & $6-19.77$ & Paleontology \\
\hline 431 & 7.19 .77 & Paleontology \\
\hline 431 & $8-18.77$ & $\begin{array}{l}\text { Porosity and } \\
\text { permcability }\end{array}$ \\
\hline 431 & $1 \cdot W L-74$ & Age date \\
\hline 431 & $2 \cdot W L-74$ & Geochemical \\
\hline 431 & 3-WL-74 & $\begin{array}{l}\text { Porosity and } \\
\text { permeability }\end{array}$ \\
\hline 431 & 4-WL-74 & Thin section \\
\hline 431 & $5-W L-74$ & $\begin{array}{l}\text { Porosity and } \\
\text { permeability }\end{array}$ \\
\hline 431 & $6-W L-74$ & Office samplc \\
\hline 431 & 7-WL.74 & Office sample \\
\hline 431 & 8-WL-74 & $\begin{array}{l}\text { Porosity and } \\
\text { permeability }\end{array}$ \\
\hline 431 & 9-WL. 74 & Age date \\
\hline 431 & $10 \cdot W L-74$ & $\begin{array}{l}\text { Porosity and } \\
\text { permeability }\end{array}$ \\
\hline 431 & 11.WL-74 & Hydrocarbon \\
\hline 431 & $12 . W L-74$ & $\begin{array}{l}\text { Porosity and } \\
\text { permeability }\end{array}$ \\
\hline 431 & 13-WL-74 & Age date \\
\hline 431 & 14-WL-74 & Age date \\
\hline 431 & 15-WL-74 & Lithology \\
\hline
\end{tabular}

\begin{tabular}{|c|c|c|}
\hline Map No. & $\begin{array}{l}\text { Sample or } \\
\text { Station No. }\end{array}$ & $\begin{array}{l}\text { Analysis or } \\
\text { Measurement }\end{array}$ \\
\hline 432 & FP13 & Gravity \\
\hline 432 & A8-JB-77 & Gcochemical \\
\hline 433 & FP12 & Gravity \\
\hline 434 & UNO6 & Gravity \\
\hline 434 & $10-\mathrm{M}-77$ & Geochemical \\
\hline 435 & FP17 & Gravity \\
\hline 436 & FP16 & Gravity \\
\hline 437 & UNOT & Gravily \\
\hline 438 & TRI.\#48 & Gravity \\
\hline 438 & $57-W L-74$ & Gcochemical \\
\hline 439 & FP15 & Gravity \\
\hline 439 & A9-JB-77 & Geochemical \\
\hline 440 & FP14 & Gravity \\
\hline 441 & UN08 & Gravity \\
\hline 441 & $11 . \int N-77$ & Geochemical \\
\hline 442 & TRI. $\# 51$ & Gravity? \\
\hline 443 & TRI.\#49 & Gravity \\
\hline 443 & 57A-WL-74 & Density \\
\hline 444 & TRI,$\# 50$ & Gravity \\
\hline 445 & UN09 & Gravity \\
\hline 445 & 12.JM-77 & Geochemical \\
\hline 445 & $13-\{M-77$ & Geochemical \\
\hline 445 & $14-1 \mathrm{M}-77$ & Geochemical \\
\hline
\end{tabular}
TABLE IB-SAMPLE OR STATION NUMBERS TOMAP NUMBERS

SAMPLING BY J. A. MOREHOUSE

\section{Random Sampling}

Sample No. Map No.

$\begin{array}{rr}1 . J M-77 & 174 \\ 2-\int M-77 & 163 \\ 3-J M-77 & 162 \\ 4-J M-77 & 167 \\ 5-J M-77 & 173 \\ 6-\int M-77 & 181 \\ 7 \cdot J M-77 & 414 \\ 8 . J M-77 & 426 \\ \text { 9-JM-77 } & 427 \\ 10-\int M-77 & 434\end{array}$




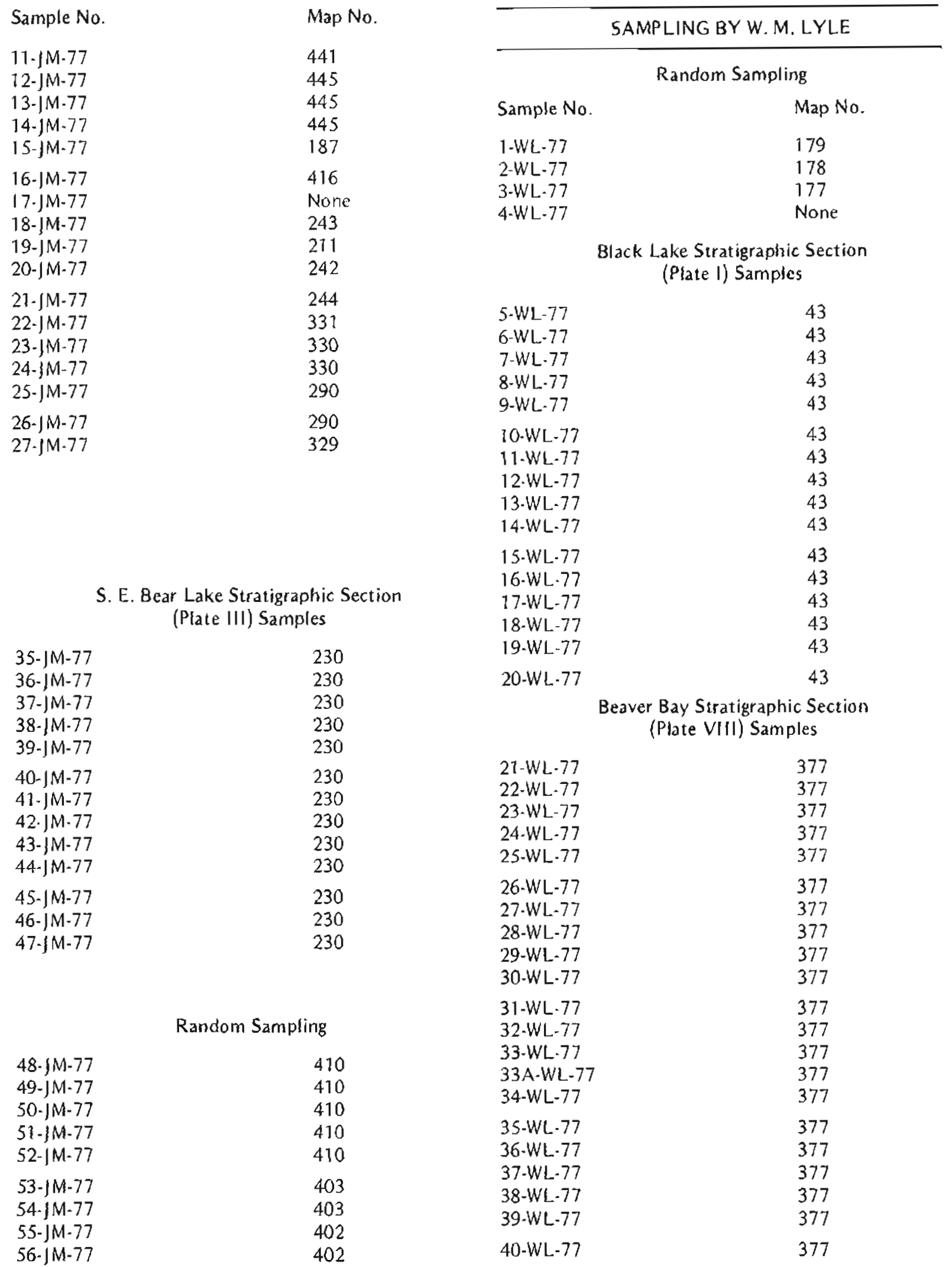




\begin{tabular}{|c|c|c|c|}
\hline Sample No & Map No. & Sample No. & Map No. \\
\hline \multirow{2}{*}{\multicolumn{2}{|c|}{$\begin{array}{l}\text { Aliaksin Peninsula Stratigraphic Section } \\
\text { (Plate X) Samples }\end{array}$}} & 82-WL-77 & 205 \\
\hline & & 83-WL-77 & 205 \\
\hline & & 84-WL-77 & 205 \\
\hline 42-WL-77 & 382 & $85-$ WL-77 & 205 \\
\hline 43.WL-77 & 382 & 86-WL-77 & 205 \\
\hline 44-WL-77 & 382 & $87 . W L .77$ & 205 \\
\hline 45-WL-77 & 382 & 88 WL-77 & 205 \\
\hline 46-WL-77 & & 89-WL-77 & 205 \\
\hline 47.WL-77 & 382 & 90 WL -77 & 205 \\
\hline 48-WL-77 & 382 & $91 \cdot W L \cdot 77$ & 205 \\
\hline 49-WL-77 & 382 & 92-WL-77 & 205 \\
\hline $50 \cdot W L-77$ & 382 & 93-WL-77 & 205 \\
\hline \multirow[t]{4}{*}{$51 \cdot W L-77$} & 382 & 94-WL-77 & 205 \\
\hline & & 9S-WL-77 & 205 \\
\hline & \multirow{2}{*}{$\begin{array}{l}\text { White Bluff Stratigraphic Section } \\
\text { (Plate XI) Samples }\end{array}$} & $96-W L-77$ & 205 \\
\hline & & 97-WL-77 & 205 \\
\hline 52-WL-77 & 391 & 98-WL-77 & 205 \\
\hline $53-W L-77$ & 391 & 99-WL-77 & 205 \\
\hline 54WL-77 & 391 & 100-WL-77 & 205 \\
\hline 55-WL-77 & 391 & $101-W L-77$ & 205 \\
\hline $56 \cdot W L-77$ & 391 & 102-WL.77 & 205 \\
\hline $57 \cdot$ WL-77 & 391 & 103-WL-77 & 205 \\
\hline 58-WL-77 & 391 & $103 \mathrm{~A}-W L-77$ & 205 \\
\hline 59-WL-77 & 391 & 104-WL-77 & 205 \\
\hline $60-W L-77$ & 391 & 105-WL-77 & 205 \\
\hline 61-WL-77 & 391 & & \\
\hline 62-WL.77 & 391 & & \\
\hline 63-WL-77 & 391 & & \\
\hline 64-WL-77 & 391 & & \\
\hline $\begin{array}{l}65-W L-77 \\
66-W L-77\end{array}$ & $\begin{array}{l}391 \\
391\end{array}$ & \multicolumn{2}{|c|}{ SAMPLING BY f. G. BOLM } \\
\hline 67.WL. 77 & 391 & \multirow{2}{*}{\multicolumn{2}{|c|}{ Random Sampling }} \\
\hline $68-W L .77$ & 391 & & \\
\hline 69-WL-77 & 391 & & \\
\hline 70-WL-77 & 391 & Sample No. & Map No. \\
\hline $71 \cdot$ WL-77 & 391 & & \\
\hline \multirow[t]{4}{*}{ 72-WL-77 } & 391 & A2. $18-77$ & $\begin{array}{l}193 \\
394\end{array}$ \\
\hline & & A3-JB-77 & 195 \\
\hline & ic Section & A4-JB-77 & 425 \\
\hline & & A5-JB-77 & 424 \\
\hline 72A-WL-77 & 205 & $A 6-18.77$ & 423 \\
\hline 73-WL-77 & 205 & A7. $18-77$ & 420 \\
\hline 74-WL.77 & 205 & $A 8 \cdot 1 B-77$ & 432 \\
\hline 75-WL-77 & 205 & A9-13-77 & 439 \\
\hline $76-W L-77$ & 205 & A $10-\mid B-77$ & 428 \\
\hline 77-WL-77 & 205 & $6.1 B-77$ & 422 \\
\hline 78-WL-77 & 205 & $7-\int B-77$ & 422 \\
\hline 79.WL.77 & 205 & $9 . j \mathrm{~B} .77$ & 422 \\
\hline 80-WL-77 & 205 & $24 \cdot j 8-77$ & 417 \\
\hline $81-W L-77$ & 205 & $25-\mathrm{JB}-77$ & 416 \\
\hline
\end{tabular}




\begin{tabular}{|c|c|c|c|}
\hline Sample No. & Map No. & Sample No. & Map No. \\
\hline $\begin{array}{l}29-1 \mathrm{~B}-77 \\
30-1 \mathrm{~B}-77\end{array}$ & $\begin{array}{l}40 \\
39\end{array}$ & $\begin{array}{l}\text { 77-SWH-04A } \\
\text { 77-SWH-05A }\end{array}$ & $\begin{array}{l}422 \\
422\end{array}$ \\
\hline $31-j 8-77$ & 38 & 77-SWH-01 & 420 \\
\hline $32 . j 8.77$ & 29 & 77.SWH.018 & 420 \\
\hline 33.$\} \mathrm{B}-77$ & 26 & 77.SWH.02 & 424 \\
\hline $34 J \mathrm{~B} .77$ & 27 & 77-SWH-03 & 424 \\
\hline $35-18-77$ & 27 & 77.5WH-04 & 424 \\
\hline $36-1 \mathrm{~B} \cdot 77$ & 28 & 77.SWH-OS & 424 \\
\hline $37.1 \mathrm{~B}-77$ & 28 & 77.SWH-06 & 424 \\
\hline $38-\int B-77$ & 14 & 77.SWH-07 & 424 \\
\hline $39-j B-77$ & 35 & $77.5 W H .08$ & 424 \\
\hline $40 \cdot 18 \cdot 77$ & 16 & 77.SWH-09 & 424 \\
\hline $41 \cdot 18 \cdot 77$ & 17 & 77-SWH.11 & 321 \\
\hline $42-J \mathrm{~B}-77$ & 18 & 77.SWH.12 & 321 \\
\hline $43-1 \mathrm{~B}-77$ & 19 & 77-SWH-12A & 369 \\
\hline $44-18-77$ & 20 & $77.5 W H-13$ & 369 \\
\hline 45.58 .77 & 30 & 77-SWH-14 & 59 \\
\hline $46-j 8-77$ & 31 & & \\
\hline $47 \cdot \mathrm{J} 8 \cdot 77$ & 32 & & \\
\hline $48-J B-77$ & 35 & & \\
\hline 49. $\} \mathrm{B} \cdot 77$ & 62 & \multicolumn{2}{|c|}{ SAMPLING BY J. G. BOLM } \\
\hline $98-\{B-7\}$ & 411 & \\
\hline $99-1 \mathrm{~B}-77$ & 408 & \multirow{3}{*}{\multicolumn{2}{|c|}{$\begin{array}{l}\text { Waterfall Point Stratigraphic Section } \\
\text { (Plate VI) Samples }\end{array}$}} \\
\hline 100-JB-77 & 409 & & \\
\hline $101-18 \cdot 77$ & 407 & & \\
\hline $102-\mathrm{J}-77$ & 406 & Sample No. & Map No. \\
\hline $103-j 8-77$ & 413 & $1 . \mathrm{GB}-77$ & 322 \\
\hline $104-18-77$ & 404 & $2-G B-77$ & 322 \\
\hline $105-\{8-77$ & 405 & $3-G B-77$ & 322 \\
\hline $106-\int B \cdot 77$ & 412 & 3.GB-77 & 322 \\
\hline \multirow{5}{*}{ 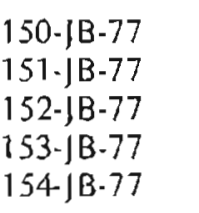 } & 366 & $4-G B-77$ & 322 \\
\hline & 366 & $5 \cdot \mathrm{GB}-77$ & 322 \\
\hline & 368 & 6.GB.77 & 322 \\
\hline & 334 & $7-G 8-77$ & 322 \\
\hline & 335 & 8-GB-77 & 322 \\
\hline \multirow{6}{*}{$\begin{array}{l}155-\mid \mathrm{B}-77 \\
156-\mathrm{B}-77 \\
157-\mathrm{B} \cdot 77 \\
158-\mathrm{B}-77\end{array}$} & 332 & $9-\mathrm{GB}-77$ & 322 \\
\hline & 333 & $10-G 8.77$ & 322 \\
\hline & 293 & $11 \cdot G B-77$ & 322 \\
\hline & & $12-\mathrm{GB}-77$ & 322 \\
\hline & & $13-G B-77$ & 322 \\
\hline & & 14-GB-77 & 322 \\
\hline \multicolumn{2}{|c|}{ 5AMPLING BY STEVE HACKETT } & $15 \cdot G B \cdot 77$ & 322 \\
\hline \multicolumn{2}{|c|}{ Random Sampling } & \multicolumn{2}{|c|}{$\begin{array}{c}\text { Balboa Bay Stratigraphic Section } \\
\text { (Plate VII) Samples }\end{array}$} \\
\hline Sample No. & Map No. & 16.GB-77 & 369 \\
\hline 77-SWH-01A & 422 & 18-GB-77 & $\begin{array}{l}369 \\
369\end{array}$ \\
\hline 77-SWH-02A & 422 & 19-GB-77 & 369 \\
\hline 77-SWH-03A & 422 & $20-G 8-77$ & 369 \\
\hline
\end{tabular}




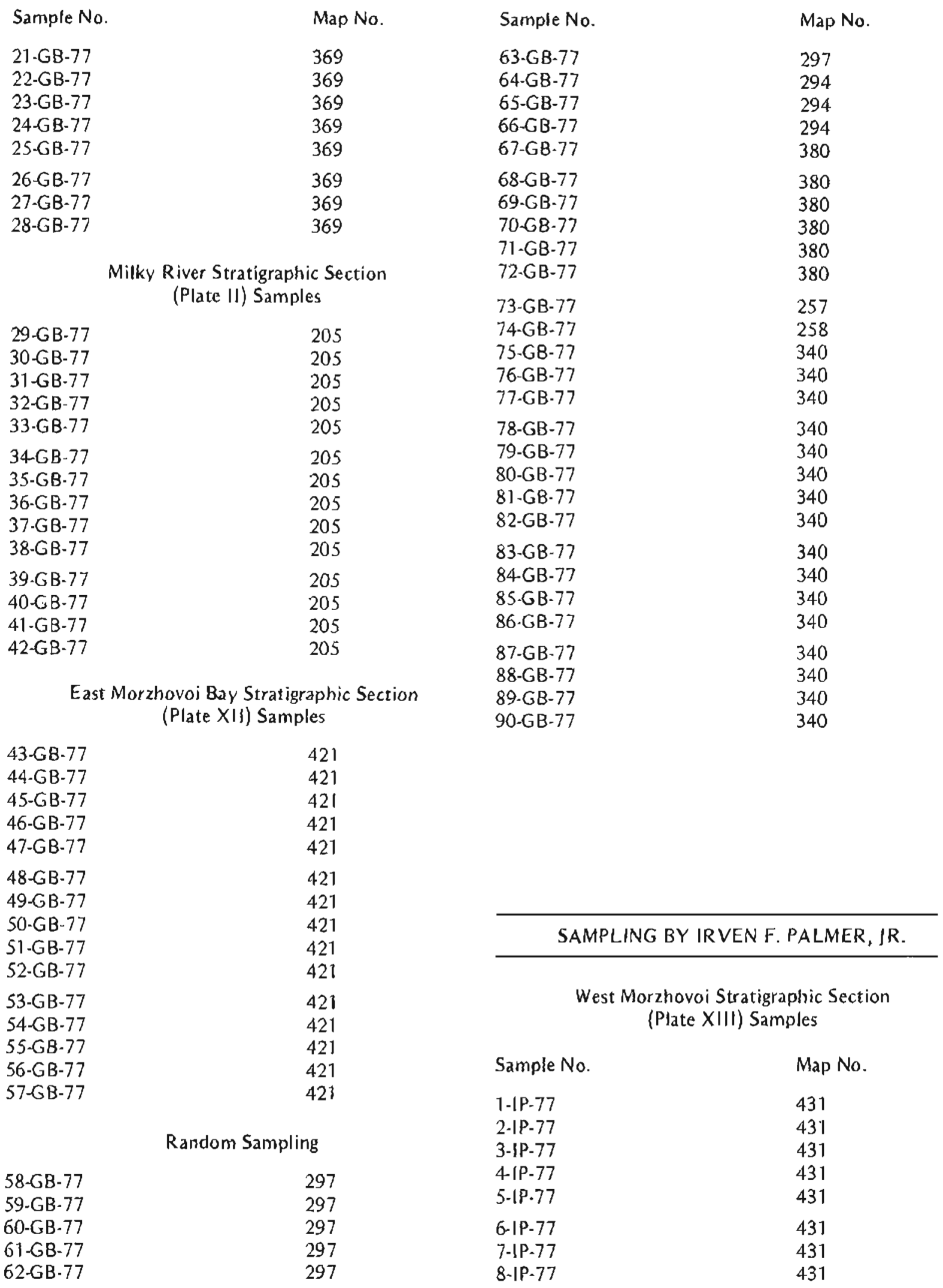




\begin{tabular}{|c|c|}
\hline Sample No. & Map No. \\
\hline \multicolumn{2}{|c|}{$\begin{array}{c}\text { Lefthand Bay-Balboa Bay Stratigraphic Secrion } \\
\text { (Plate VII) Samples }\end{array}$} \\
\hline $\begin{array}{r}9.1 P .77 \\
10.1 P .77 \\
11-I P .77 \\
12-1 P .77 \\
13.1 P .77\end{array}$ & $\begin{array}{l}369 \\
369 \\
369 \\
369 \\
369\end{array}$ \\
\hline $\begin{array}{l}14-I P .77 \\
15-1 P-77 \\
16-1 P-77 \\
17-1 P-77 \\
18-1 P-77\end{array}$ & $\begin{array}{l}369 \\
369 \\
369 \\
369 \\
369\end{array}$ \\
\hline $\begin{array}{l}19-1 P-77 \\
20-1 P-77 \\
21-1 P .77 \\
22-1 P .77 \\
23-1 P .77\end{array}$ & $\begin{array}{l}369 \\
369 \\
369 \\
369 \\
369\end{array}$ \\
\hline $\begin{array}{l}24-I P-77 \\
25-I P-77\end{array}$ & $\begin{array}{l}369 \\
369\end{array}$ \\
\hline
\end{tabular}

Heren I and II Stratigraphic Sections (Plates IV and V) Samples

$\begin{array}{ll}26-I P-77 & 291 \\ 27-1 P-77 & 291 \\ 28-1 P-77 & 291 \\ 29-1 P-77 & 291 \\ 30-1 P-77 & 291 \\ 31-I P-77 & 291 \\ 32-1 P-77 & 291 \\ 33-1 P-77 & 291 \\ 34-1 P-77 & 291 \\ 35-I P-77 & 291 \\ 36-I P-77 & 291 \\ 37-1 P-77 & 291 \\ 38-I P-77 & 291 \\ 39-1 P-77 & 291 \\ 40-I P-77 & 291 \\ 41-1 P-77 & 291 \\ 42-1 P-77 & 291 \\ 43-1 P-77 & 291 \\ 44-1 P-77 & 291 \\ 45-1 P-77 & 291 \\ 46-1 P-77 & 291 \\ 47-I P-77 & 291 \\ 48-1 P-77 & 291 \\ 49-1 P-77 & 291 \\ 50-I P-77 & 291 \\ 51-1 P-77 & 291 \\ 52-I P-77 & 291 \\ 53-1 P-77 & 291\end{array}$

26-1P-77

$27-18-77$

29-1P.77

30-1P.77

$33-1 P-77$

$34-1 P-77$

$36-1 \mathrm{P}-77$

37-1P.77

38-IP.77

39.1P.77

40-IP.7

$42+18-77$

43.1P.77

44-1P.77

46.19 .77

49-1P-77

$51 \cdot 1 \mathrm{P} .77$

$53.1 \mathrm{P} .77$
Sample No.

54-1P.77

$55.1 P .77$

56-1P. 77

$57-1 \mathrm{P} .77$

58.1P.77

$59.1 \mathrm{P}-77$

$60.1 P .77$

61-1P.77

62-1P.77

63-1P.77

64-1P-77

$65 \cdot 1 P .77$

66-1P.77

$67.1 P .77$
Map No.

398

401

399

397

396

395

394

390

2

2

2

1

1

SAMPLING BY W.M. LYLE

West Morzhovoi Bay Stratigraphic Section (Plate XIII) Samples

Sample No.

1-WL-74

2.WL-74

3.WL-74

4-WL-74

S-WL-74

6.WL-74

7-WL-74

8.WL.74

9-WL-74

10-WL-74

11-WL-74

12-WL-74

33-WL-74

14-WL-74

15-WL-74

16-WL-74

17-WL-74

18-WL-74

19-WL-74

20-WL-74

21-WL-74

22-WL-74

23.WL-74

24-WL-74

25-WL-74
Map No.

431

431

431

431

431

431

431

431

431

431

431

431

431

431

431

$188 \mathrm{~A}$

374

$355 \mathrm{~A}$

347

385

365

$335 \mathrm{~A}$

$335 \mathrm{~A}$

$335 \mathrm{~A}$

$335 \mathrm{~A}$ 


\begin{tabular}{|c|c|c|c|}
\hline Sample No. & Map No. & Sample No. & Map No. \\
\hline $\begin{array}{l}26-W L-74 \\
27-W L-74 \\
28-W L-74 \\
29-W L-74 \\
30-W L-74\end{array}$ & $\begin{array}{l}295 \\
295 \\
298 \\
299 \\
345\end{array}$ & $\begin{array}{l}63-W L-74 \\
64-W L-74 \\
65-W L-74 \\
66-W L-74 \\
67-W L-74\end{array}$ & $\begin{array}{l}272 \\
279 \\
224 \\
271 \\
280\end{array}$ \\
\hline $\begin{array}{l}31-W L-74 \\
32-W L-74 \\
33-W L-74 \\
34-W L-74 \\
35-W L-74\end{array}$ & $\begin{array}{l}349 \\
349 \\
355 \\
350 \\
350\end{array}$ & $\begin{array}{l}\text { 68-WL-74 } \\
69-W L-74 \\
70-W L-74 \\
71-W L-74 \\
72-W L-74\end{array}$ & $\begin{array}{l}280 \\
270 \\
272 \\
276 \\
278\end{array}$ \\
\hline $\begin{array}{l}36-W L-74 \\
37-W L-74 \\
38-W L-74 \\
39-W L-74 \\
40-W L-74\end{array}$ & $\begin{array}{l}350 \\
176 \\
196 \\
197 \\
197\end{array}$ & $\begin{array}{l}73-W L-74 \\
74 W L-74 \\
75-W L-74 \\
76-W L-74 \\
77-W L-74\end{array}$ & $\begin{array}{l}278 \\
277 \\
273 \\
275 \\
275\end{array}$ \\
\hline $\begin{array}{l}41-W L-74 \\
42-W L-74 \\
43-W L-74 \\
44-W L-74 \\
45-W L-74\end{array}$ & $\begin{array}{l}198 \\
155 \\
155 \\
156 \\
364\end{array}$ & $\begin{array}{l}78-W L \cdot 74 \\
79-W L-74 \\
80-W L \cdot 74 \\
81-W L \cdot 74 \\
82-W L-74\end{array}$ & $\begin{array}{l}281 \\
228 \\
229 \\
229 \\
233\end{array}$ \\
\hline & & $\begin{array}{l}83-W L-74 \\
84-W L-74\end{array}$ & $\begin{array}{l}232 \\
231\end{array}$ \\
\hline
\end{tabular}

Balboa Bay Stratigraphic Section (Plate VII) Samples

46-WL-74
47-WL-74
48-WL-74
49-WL-74 369 369 369 369

Random Sampling

Sample No.

50-WL-74

51-WL-74

52-WL.74

53.WL.74

54-WL-74

55.WL-74

56-WL. 74

57-WL-74

57A.WL-74

58-WL-74

59-WL-74

60.WL-74

60A-WL-74

61-WL-74

62.WL-74
Map No.

296

160

159

191

192

189

438

438

443

124

117

111

112

221

269
Beaver Bay East Stratigraphic Section (Plate IX) Samples

$\begin{array}{ll}\text { 85-WL-74 } & 378 \\ \text { 86-WL-74 } & 378 \\ \text { 87-WL-74 } & 378 \\ \text { 88-WL-74 } & 378 \\ 89-W L-74 & 378 \\ \text { 90-WL-74 } & 378 \\ \text { 91A-WL-74 } & 378 \\ \text { 92-WL-74 } & 378 \\ 92 \text { A-WL-74 } & 378 \\ \text { 93-WL-74 } & 378 \\ \text { 94-WL-74 } & 378 \\ \text { 95-WL-74 } & 378 \\ \text { 96-WL-74 } & 378 \\ \text { 97-WL-74 } & 378 \\ \text { 98-WL-74 } & 378 \\ \text { 99-WL-74 } & 378 \\ \text { 100-WL-74 } & 378 \\ \text { 101-WL-74 } & 378 \\ \text { 102-WL-74 } & 378 \\ \text { 103-WL-74 } & 378 \\ \text { 104-WL-74 } & 378 \\ \text { 105-WL-74 } & 378 \\ \text { 106-WL-74 } & 378 \\ \text { 107-WL-74 } & 378 \\ \text { 108-WL-74 } & 378\end{array}$




\begin{tabular}{|c|c|c|c|}
\hline Sample No. & Map No. & Sample No. & Map No. \\
\hline 109-WL.74 & 378 & 156-WL-74 & 267 \\
\hline 110-WL-74 & 378 & 157-WL. 74 & 259 \\
\hline $111-W L \cdot 74$ & 378 & 158-WL.74 & 256 \\
\hline $112-W L-74$ & 378 & 159-WL-74 & 256 \\
\hline \multirow[t]{3}{*}{ 113-WL.74 } & 378 & 160-WL-74 & 255 \\
\hline & & 161-WL-74 & 255 \\
\hline & & 162-WL-74 & 251 \\
\hline $\begin{array}{l}\text { 114-WL-74 } \\
115-W L-74 \\
116-W L-74 \\
117-W L-74 \\
118-W L-74\end{array}$ & $\begin{array}{l}356 \\
308 \\
319 \\
371 \\
371\end{array}$ & $\begin{array}{l}\text { 163-WL-74 } \\
\text { 164-WL-74 } \\
\text { 165-WL-74 } \\
\text { 166-WL-74 } \\
\text { 167-WL-74 }\end{array}$ & $\begin{array}{l}251 \\
300 \\
300 \\
302 \\
304\end{array}$ \\
\hline 119-WL-74 & 354 & 168-WL-74 & 367 \\
\hline $120 \cdot$ WL- 74 & 351 & & \\
\hline $121 \cdot W L \cdot 74$ & 351 & \multirow{3}{*}{\multicolumn{2}{|c|}{$\begin{array}{c}\text { Beaver Bay East Stratigraphic Section } \\
\text { (Plate IX) Samples }\end{array}$}} \\
\hline 122-WL-74 & 352 & & \\
\hline & & & \\
\hline 124-WL-74 & 353 & $\begin{array}{l}\text { 169-WL-74 } \\
170-W:-74\end{array}$ & $\begin{array}{l}378 \\
378\end{array}$ \\
\hline 125-WL.-74 & 353 & & $\begin{array}{l}378 \\
778\end{array}$ \\
\hline 126-WL-74 & 344 & 171-WL-74 & 378 \\
\hline 127.WL.74 & 338 & 172-WL-74 & 378 \\
\hline 128-WL.74 & 339 & 173-WL-74 & \\
\hline 129-WL-74 & 339 & 174-WL-74 & 378 \\
\hline $130-$ WL-74 & 341 & 175.WL-74 & 378 \\
\hline 131-WL-74 & 341 & $176-W L-74$ & 378 \\
\hline 132-WL-74 & 337 & 177-WL-74 & 378 \\
\hline 133-WL-74 & 336 & 178-WL-74 & 378 \\
\hline 133B-WL-74 & 336 & 179-WL-74 & 378 \\
\hline $134 W L-74$ & 343 & 180-WL-74 & 378 \\
\hline 135-WL-74 & 346 & 181-WL-74 & 378 \\
\hline 136-WL-74 & 348 & 182-WL-74 & 378 \\
\hline 137-WL-74 & 348 & $183-W L-74$ & 378 \\
\hline 138-WL-74 & 310 & 184WL-74 & 378 \\
\hline 139-WL.74 & 312 & 185.WL-74 & 378 \\
\hline 140-WL-74 & 312 & 186-WL-74 & 378 \\
\hline 141-WL-74 & 309 & 187-WL-74 & 378 \\
\hline 142-WL-74 & 266 & 188-WL-74 & 378 \\
\hline 143-WL-74 & 260 & 189-WL-74 & 378 \\
\hline 344-WL-74 & 110 & \multirow{2}{*}{\multicolumn{2}{|c|}{ Random Sampling }} \\
\hline 145-WL-74 & 318 & & \\
\hline 146-WL-74 & 316 & 190-WL-74 & 378 \\
\hline 147-WL-74 & 316 & 191 -WL.74 & 381 \\
\hline 148-WL-74 & 335 & 192-WL-74 & 342 \\
\hline 149-WL. 74 & 314 & 193-WL-74 & 342 \\
\hline 150-WL-74 & 314 & 194-WL-74 & 311 \\
\hline 151.WL-74 & 313 & $195-W L \cdot 74$ & 311 \\
\hline $152-$ WL- 74 & 313 & 197-WL-74 & 222 \\
\hline 153-WL-74 & 267 & 198-WL-74 & 223 \\
\hline 154WL-74 & 267 & 199.WL.74 & 204 \\
\hline 155-WL-74 & 267 & $200-W L-74$ & 227 \\
\hline
\end{tabular}




\begin{tabular}{|c|c|c|c|}
\hline Sample No. & Map No. & Sample No. & Map No. \\
\hline $\begin{array}{l}\text { 201-WL-74 } \\
202-W L-74 \\
203-W L-74 \\
204-W L-74 \\
205-W L-74\end{array}$ & $\begin{array}{l}226 \\
282 \\
282 \\
283 \\
283\end{array}$ & $\begin{array}{l}\text { 250-WL.74 } \\
251-W L-74 \\
252-W L .74 \\
253-W L .74 \\
254-W L .74\end{array}$ & $\begin{array}{r}99 \\
100 \\
100 \\
100 \\
100\end{array}$ \\
\hline $\begin{array}{l}\text { 206-WL-74 } \\
207-W L-74 \\
208-W L-74 \\
209-W L-74 \\
210-W L-74\end{array}$ & $\begin{array}{l}283 \\
283 \\
283 \\
283 \\
283\end{array}$ & $\begin{array}{l}\text { 255-WL-74 } \\
256-W L-74 \\
257 \cdot W L-74 \\
258-W L-74 \\
259-W L-74\end{array}$ & $\begin{array}{r}101 \\
101 \\
102 \\
102 \\
73\end{array}$ \\
\hline $\begin{array}{l}211-W L-74 \\
212-W L-74 \\
213-W L-74 \\
214-W L-74 \\
215-W L-74\end{array}$ & $\begin{array}{l}320 \\
266 \\
207 \\
207 \\
307\end{array}$ & $\begin{array}{l}260-W L-74 \\
26\} \cdot W L-74 \\
262 \cdot W L-74 \\
263 \cdot W L-74 \\
264-W L-74\end{array}$ & $\begin{array}{l}73 \\
73 \\
73 \\
56 \\
56\end{array}$ \\
\hline $\begin{array}{l}216-W L-74 \\
217-W L-74 \\
218-W L-74 \\
219-W L-74 \\
220-W L-74\end{array}$ & $\begin{array}{l}206 \\
206 \\
306 \\
305 \\
258\end{array}$ & $\begin{array}{l}265 \cdot W L-74 \\
266 \cdot W L-74 \\
267-W L-74 \\
268 \cdot W L-74 \\
269-W L-74\end{array}$ & $\begin{array}{l}56 \\
56 \\
56 \\
45 \\
57\end{array}$ \\
\hline $\begin{array}{l}221-W L-74 \\
222-W L-74 \\
223-W L-74 \\
224-W L-74 \\
225-W L-74\end{array}$ & $\begin{array}{l}359 \\
360 \\
360 \\
357 \\
303\end{array}$ & $\begin{array}{l}270-W L-74 \\
271-W L-74 \\
272-W L-74 \\
273-W L-74 \\
274-W L-74\end{array}$ & $\begin{array}{l}57 \\
57 \\
57 \\
53 \\
54\end{array}$ \\
\hline $\begin{array}{l}226 \cdot W L \cdot 74 \\
227 \cdot W L-74 \\
228 \cdot W L-74 \\
229-W L-74 \\
230 \cdot W L \cdot 74\end{array}$ & $\begin{array}{l}303 \\
303 \\
361 \\
373 \\
373\end{array}$ & $\begin{array}{l}275 \text {-WL-74 } \\
276-W L-74 \\
277-W L-74 \\
278-W L-74 \\
279-W L-74\end{array}$ & $\begin{array}{l}52 \\
66 \\
67 \\
68 \\
85\end{array}$ \\
\hline $\begin{array}{l}231-W L-74 \\
232-W L-74 \\
233-W L-74 \\
234-W L-74 \\
235-W L-74\end{array}$ & $\begin{array}{l}384 \\
384 \\
384 \\
384 \\
384\end{array}$ & $\begin{array}{l}280-W L-74 \\
281-W L-74 \\
282-W L-74 \\
283-W L-74 \\
284-W L-74\end{array}$ & $\begin{array}{l}87 \\
86 \\
86 \\
41 \\
41\end{array}$ \\
\hline $\begin{array}{l}236-W L-74 \\
237-W L-74 \\
238-W L-74 \\
239-W L-74 \\
240-W L-74\end{array}$ & $\begin{array}{l}383 \\
254 \\
301 \\
262 \\
262\end{array}$ & $\begin{array}{l}285-W L-74 \\
286-W L-74 \\
287-W L-74 \\
288-W L-74 \\
289 \cdot W L-74\end{array}$ & $\begin{array}{l}69 \\
72 \\
71 \\
71 \\
71\end{array}$ \\
\hline $\begin{array}{l}241 \cdot W L-74 \\
242-W L-74 \\
243-W L-74 \\
244-W L-74 \\
245-W L-74\end{array}$ & $\begin{array}{l}262 \\
262 \\
262 \\
263 \\
265\end{array}$ & $\begin{array}{l}290-W L-74 \\
291-W L-74 \\
292-W L-74 \\
293-W L-74 \\
294-W L-74\end{array}$ & $\begin{array}{l}71 \\
71 \\
70 \\
70 \\
70\end{array}$ \\
\hline $\begin{array}{l}246 \cdot W L \cdot 74 \\
247 \cdot W L \cdot 74 \\
248 \cdot W L-74 \\
248 \cdot W L-74 \\
249 \cdot W L-74\end{array}$ & $\begin{array}{r}265 \\
265 \\
265 \\
95 \\
99\end{array}$ & $\begin{array}{l}\text { 295-WL-74 } \\
296-W L-74 \\
297-W L-74 \\
298-W L-74 \\
299-W L-74\end{array}$ & $\begin{array}{l}70 \\
70 \\
70 \\
70 \\
70\end{array}$ \\
\hline
\end{tabular}




\begin{tabular}{|c|c|c|c|}
\hline Sample No. & Map No. & Sample No. & Map No. \\
\hline $\begin{array}{l}\text { 300-WL-74 } \\
301 \cdot W L-74 \\
302-W L-74 \\
303-W L-74 \\
304-W L-74\end{array}$ & $\begin{array}{l}70 \\
88 \\
88 \\
88 \\
89\end{array}$ & $\begin{array}{l}\text { 338-WL-74 } \\
339 \cdot \text { WL-74 } \\
340-W L-74 \\
\text { 341-WL-74 } \\
\text { 342-WL-74 }\end{array}$ & $\begin{array}{l}102 \mathrm{~L} \\
102 \mathrm{~L} \\
102 \mathrm{~L} \\
102 \mathrm{~L} \\
102 \mathrm{~L}\end{array}$ \\
\hline $\begin{array}{l}\text { 305-WL-74 } \\
306-W L-74 \\
307-W L-74 \\
308-W L-74 \\
309-W L-74\end{array}$ & $\begin{array}{l}89 \\
89 \\
90 \\
90 \\
90\end{array}$ & $\begin{array}{l}\text { 343-WL-74 } \\
\text { 344-WL-74 } \\
\text { 345-WL-74 } \\
\text { 350-WL-74 } \\
\text { 351-WL-74 }\end{array}$ & $\begin{array}{l}102 L \\
102 L \\
\text { None } \\
1021 \\
1021\end{array}$ \\
\hline $\begin{array}{l}\text { 310-WL-74 } \\
311-W L-74 \\
312-W L-74 \\
313-W L-74 \\
314 W L-74\end{array}$ & $\begin{array}{l}90 \\
91 \\
91 \\
91 \\
75\end{array}$ & $\begin{array}{l}\text { 352-WL-74 } \\
353-W L-74 \\
354-W L-74 \\
355-W L-74 \\
356-W L-74\end{array}$ & $\begin{array}{l}102 ! \\
102 ! \\
1021 \\
102\rfloor \\
102 j\end{array}$ \\
\hline $\begin{array}{l}314.1 \text { WL-74 } \\
314.2 \cdot \text { WL-74 } \\
314.3 \text { WL-74 } \\
314.4 \text { WL-74 } \\
\text { 314.6.WL-74 }\end{array}$ & $\begin{array}{l}75 \\
75 \\
75 \\
75 \\
75\end{array}$ & $\begin{array}{l}357 \cdot W L-74 \\
358 \cdot W L-74 \\
359 \cdot W L-74 \\
360 \cdot W L-74 \\
361-W L-74\end{array}$ & $\begin{array}{l}102 J \\
102 \mathrm{D} \\
102 \mathrm{D} \\
102 \mathrm{E} \\
102 \mathrm{~F}\end{array}$ \\
\hline $\begin{array}{l}\text { 314.7-WL-74 } \\
314.8 \text { WL-74 } \\
314.9-W L-74 \\
314.10-W L-74 \\
314.11-W L-74\end{array}$ & $\begin{array}{l}76 \\
76 \\
76 \\
76 \\
76\end{array}$ & $\begin{array}{l}\text { 362-WL-74 } \\
363-W L-74 \\
364-W L-74 \\
365-W L-74 \\
366-W L \cdot 74\end{array}$ & $\begin{array}{l}102 \mathrm{M} \\
102 \mathrm{M} \\
102 \mathrm{M} \\
102 \mathrm{M} \\
102 \mathrm{M}\end{array}$ \\
\hline $\begin{array}{l}\text { 314.12-WL-74 } \\
\text { 314.13-WL-74 } \\
\text { 315-WL-74 } \\
\text { 316-WL-74 } \\
\text { 317-WL-74 }\end{array}$ & $\begin{array}{c}74 \\
74 \\
50 \\
55 \\
72 \text { or } 43\end{array}$ & \multicolumn{2}{|c|}{$\begin{array}{l}\text { TABLE IC-GRAVITY STATION NUMBERS } \\
\text { TO MAP NUMBERS }\end{array}$} \\
\hline $\begin{array}{l}318-W L-74 \\
319-W L-74 \\
320-W L-74 \\
321-W L-74 \\
322-W L-74\end{array}$ & $\begin{array}{c}44 \\
102 \mathrm{~A} \\
102 \mathrm{~B} \\
102 \mathrm{C} \\
102 \mathrm{C}\end{array}$ & \multicolumn{2}{|c|}{$\begin{array}{c}\text { TABLE 1C-GRAVITY STATION NUMBERS } \\
\text { TOMAP NUMBERS }\end{array}$} \\
\hline $\begin{array}{l}323-W L-74 \\
324-W L-74 \\
325-W L-74 \\
326-W L-74 \\
327-W L-74\end{array}$ & $\begin{array}{l}102 \mathrm{C} \\
102 \mathrm{C} \\
102 \mathrm{C} \\
102 \mathrm{C} \\
102 \mathrm{~K}\end{array}$ & $\begin{array}{l}\text { Gravity } \\
\text { Station No. }\end{array}$ & Map No. \\
\hline $\begin{array}{l}328-W L-74 \\
329-W L-74 \\
330-W L-74 \\
331-W L-74 \\
\text { 332-WL-74 }\end{array}$ & $\begin{array}{l}102 \mathrm{~K} \\
102 \mathrm{~K} \\
102 \mathrm{G} \\
102 \mathrm{H} \\
102 \mathrm{H}\end{array}$ & $\begin{array}{l}\text { FP01 } \\
\text { FP02 } \\
\text { FP03 } \\
\text { FP04 } \\
\text { FP05 }\end{array}$ & $\begin{array}{l}175 \\
193 \\
194 \\
195 \\
425\end{array}$ \\
\hline $\begin{array}{l}\text { 333-WL-74 } \\
334 \text { WL-74 } \\
335-W L-74 \\
336-W L-74 \\
337-W L-74\end{array}$ & $\begin{array}{l}102 \mathrm{~L} \\
102 \mathrm{~L} \\
102 \mathrm{~L} \\
102 \mathrm{~L} \\
102 \mathrm{~L}\end{array}$ & $\begin{array}{l}\text { FP06 } \\
\text { FPO7 } \\
\text { FP08 } \\
\text { FP09 } \\
\text { FP10 }\end{array}$ & $\begin{array}{l}424 \\
423 \\
421 \mathrm{~A} \\
420 \\
419\end{array}$ \\
\hline
\end{tabular}




\begin{tabular}{lc}
$\begin{array}{l}\text { Gravity } \\
\text { Station No. }\end{array}$ & Map No. \\
FP11 & 418 \\
FP12 & 433 \\
FP13 & 432 \\
FP14 & 440 \\
FP15 & 439 \\
FP16 & 436 \\
FP17 & 435 \\
FP18 & 429 \\
FP19 & 428 \\
FP20 & 430 \\
\hline
\end{tabular}

Gravity

Station No.

Map No.

$\begin{array}{ll}\text { UN03 } & 414 \\ \text { UN04 } & 426 \\ \text { UN05 } & 427 \\ \text { UN06 } & 434 \\ \text { UN07 } & 437 \\ \text { UN08 } & 441 \\ \text { UN09 } & 445 \\ \text { UN10 } & 415 \\ \text { UN11 } & 187 \\ \text { UN12 } & 416 \\ \text { UN13 } & 179 \\ \text { UN14 } & 178 \\ \text { UN15 } & 177\end{array}$

\section{Graviry}

Station No.

Map No.

IZ01

IZ02

IZO3

1204

IZ05

IZ06

IZOT

1208

IZO9

IZ10

IZ11

1212

IZ13

IZ14

IZ15

IZ16

1217

1218

1219

IZ20

IZ21

1222

IZ23

IZ24

UNIMAK TRAVERSE

Gravity

Station No.

UNO1

UNO2
174

173

172

169

163

161

162

164.

165

166

168

151

149

147

146

145

148

150

143

142

141

140

139

138

PAVLOV BAY TRAVERSE

Gravity

Station No. Map No.

$\begin{array}{ll}\mathrm{PBO} 01 & 218\end{array}$

$\mathrm{PBO2} 2216$

$\mathrm{PBO3} 253$

PBO4 250

PBOS 214

PBO6 246

PB07 247

PBO8 249

PBO9 248

PB10 200

PB11 241

P812 289

PB13 365

PB14 328

PB15 326

PB16 363

PB17 376

P818 386

PB19 387

P820 390A

PB21 390

PB22 389

PB23 393

PB24 392

PB25 400

PB26 375

PB27 362

PB28 323

PB29 285

PB30 235

PB37 207 


\begin{tabular}{|c|c|c|c|}
\hline \multicolumn{2}{|c|}{ MUDDY RIVER TRAVERSE } & \multicolumn{2}{|c|}{ BERING SEA TRAVERSE } \\
\hline $\begin{array}{l}\text { Gravity } \\
\text { Station No. }\end{array}$ & Map No. & $\begin{array}{l}\text { Gravity } \\
\text { Station No. }\end{array}$ & Map Na. \\
\hline $\begin{array}{l}\text { MRO1 } \\
\text { MR02 } \\
\text { MR03 } \\
\text { MR04 } \\
\text { MR05 }\end{array}$ & $\begin{array}{c}203 \mathrm{~A} \\
92 \\
58 \\
78 \\
59\end{array}$ & $\begin{array}{l}\mathrm{BSO} 1 \\
\mathrm{BSO} 2 \\
\mathrm{BSO} 3 \\
\mathrm{BSO} 4 \\
\mathrm{BSO} 5\end{array}$ & $\begin{array}{l}215 \\
203 \\
202 \\
201 \\
199\end{array}$ \\
\hline $\begin{array}{l}\text { MR06 } \\
\text { MR07 } \\
\text { MR08 } \\
\text { MR09 } \\
\text { MR30 }\end{array}$ & $\begin{array}{l}46 \\
47 \\
48 \\
49 \\
61\end{array}$ & $\begin{array}{l}\text { BS06 } \\
8507 \\
B S 08 \\
B S 09 \\
8510\end{array}$ & $\begin{array}{l}206 \\
236 \\
284 \\
103 \\
105\end{array}$ \\
\hline $\begin{array}{l}\text { MR11 } \\
\text { MR12 } \\
\text { MR } 13 \\
\text { MR } 14 \\
\text { MR15 }\end{array}$ & $\begin{array}{l}63 \\
64 \\
82 \\
83 \\
84\end{array}$ & $\begin{array}{l}\text { BS11 } \\
B S 12 \\
B S 13 \\
B S 14 \\
B S 15\end{array}$ & $\begin{array}{l}106 \\
107 \\
108 \\
109 \\
114\end{array}$ \\
\hline \multirow[t]{2}{*}{ MR16 } & 97 & $\begin{array}{l}\text { BS16 } \\
\text { BS17 } \\
\text { BS18 } \\
\text { BS19 } \\
\text { BS20 }\end{array}$ & $\begin{array}{l}116 \\
120 \\
153 \\
154 \\
125\end{array}$ \\
\hline & & $\begin{array}{l}\text { BS21 } \\
B S 22 \\
B S 23 \\
B S 24\end{array}$ & $\begin{array}{l}118 \\
126 \\
173 \\
286\end{array}$ \\
\hline \multicolumn{2}{|c|}{ SAPSUK RIVER TRAVERSE } & & \\
\hline Gravity & & \multicolumn{2}{|c|}{ PORT HEIDEN TRAVERSE } \\
\hline Station No. & Map No. & & \\
\hline $\begin{array}{l}\text { SR01 } \\
\text { SR02 } \\
\text { SR03 } \\
\text { SR04 } \\
\text { SR05 }\end{array}$ & $\begin{array}{l}243 \\
211 \\
242 \\
244 \\
331\end{array}$ & $\begin{array}{l}\text { Gravity } \\
\text { Station No. } \\
\text { PH01 } \\
\text { PH02 } \\
\text { PHO3 }\end{array}$ & $\begin{array}{l}\text { Map No. } \\
33 \\
34 \\
21\end{array}$ \\
\hline $\begin{array}{l}\text { SR06 } \\
\text { SR07 }\end{array}$ & $\begin{array}{l}330 \\
290\end{array}$ & $\begin{array}{l}\text { PH04 } \\
\text { PHO5 }\end{array}$ & $\begin{array}{l}22 \\
23\end{array}$ \\
\hline SR08 & 329 & PHO6 & 9 \\
\hline SR09 & 288 & $\mathrm{PHO} 7$ & 10 \\
\hline SR 10 & 240 & $\begin{array}{l}\text { PHO8 } \\
\text { PH09 }\end{array}$ & $\begin{array}{r}71 \\
7\end{array}$ \\
\hline SR 11 & 239 & PH1O & 6 \\
\hline $\begin{array}{l}\text { SR12 } \\
\text { SR 13 } \\
\text { SR 14 } \\
\text { SR15 }\end{array}$ & $\begin{array}{l}209 \\
238 \\
287 \\
325\end{array}$ & $\begin{array}{l}\text { PH11 } \\
\text { PH12 } \\
\text { PH13 } \\
\text { PH14 }\end{array}$ & $\begin{array}{r}5 \\
4 \\
8 \\
36\end{array}$ \\
\hline SR16 & 324 & PH16 & 96 \\
\hline
\end{tabular}


TABLE ID-TRIANGLE NUMBERS TO MAP NUMBERS

$$
\begin{array}{r}
7 \\
\hline \\
\\
7 \\
3 \\
5 \\
6 \\
8 \\
9 \\
10
\end{array}
$$

1974 TRIANGLE SECTIONS

Triangle No.

1

2

3

4

5

6

7

8

9

11

12

13

14

15

16

17

18

19

20

21

22

23

24

25

26

27

28

29

30

31

32

33

34

35

36

37

37

38

39

40

41

42

43

44
Map No.

170

431

213

374

98

$355 \mathrm{~A}$

347

385

365

$335 \mathrm{~A}$

295

298

299

431

349

349

355

350

133

176

196

197

198

155

156

364

269

None

296

296

?

160

159

191

192

190

189

189

188

186

182

183

184

185

157
Triangle No.

45

46

45

46

47

48

49

50

51

52

53

54

55

56

57

58

59

60

61

62

63

64

65

66

67

68

69

70

71

72

73

74

75

76

77

78

79

80

81

82

83

84

85

86

87

88

89

90

91

92
Map No.

158

136

135

136

135

438

443

444

442

144

137

134

130

129

128

122

121

119

115

123

132

$152 \mathrm{~A}$

152

131

124

117

111

112

104

237

219

217

220

221

268

269

272

279

224

271

280

270

272

276

278

277

273

275

274

281 
Triangle No.

93

94

95

96

97

98

99

100

101

102

103

104

105

106

107

108

109

110

111

112

113

114

115

116

117

118

119

120

121

122

123

124

125

126

127

128

129

130

131

132

133

134

135

136

137

138

139

140

141

142
Map No.

228

229

233

232

231

278

379

370

356

208

317

319

371

354

351

352

353

344

338

339

341

337

336

343

346

348

310

312

309

266

260

110

210

237A

245

318

316

315

314

313

267

259

256

255

252

251

300

302

304

367
Triangle No.

143

144

145

146

147

148

149

150

151

152

153

154

155

156

157

158

159

160

161

162

163

164

165

166

167

168

169

170

171

172

173

174

175

176

177

178

179

180

181

182

183

184

185

186

187

188

189

190

191

192
Map No.

388

381

342

331

93

222

223

204

225

227

226

282

283

320

266

307

306

264

305

358

359

360

357

303

361

372

373

384

384

383

254

301

262

263

265

59

79

80

81

94

77

95

99

100

101

102 
Triangle No.

193

194

195

196

197

198

199

200

201

202

203

204

205

206

207

208

209

210

211

212

213

214

215

216

217

218

219

220

221

222

223

224

225

226

227

228

229

230

231

232

234

235

236

237

238

239

240

241

242

243
Map No.

57

53

52

41

66

67

68

85

87

86

72

42

69

43

71

70

25

24

13

12

88

89

90

91

75

75

76

76

74

50

51

55

72 or 43

44

$102 \mathrm{~A}$

$102 \mathrm{~B}$

$102 \mathrm{C}$

$102 \mathrm{C}$

$102 \mathrm{C}$

$102 \mathrm{~K}$

$102 \mathrm{G}$

$102 \mathrm{H}$

$102 \mathrm{~L}$

$102 \mathrm{~L}$

$102 \mathrm{~L}$

1021

1021

$102\}$

102D
Triangle No.

244

245

246

$$
\begin{aligned}
& 102 \mathrm{E} \\
& 102 \mathrm{~J}^{\circ} \\
& 102 \mathrm{M}
\end{aligned}
$$

Map No. 
TABLE 2-THICKNESS OF STRATIGRAPHIC SECTIONS AND THICKNESS AND PERCENTAGE OF SANDSTONE

\begin{tabular}{|c|c|c|c|c|c|c|}
\hline \multirow[t]{2}{*}{$\begin{array}{l}\text { Age and } \\
\text { Srratigraphic Section }\end{array}$} & \multirow[t]{2}{*}{$\begin{array}{l}\text { Total } \\
\text { Thickness } \\
\text { in feet }\end{array}$} & \multirow[t]{2}{*}{$\begin{array}{l}\text { Percent } \\
\text { Sandstone }\end{array}$} & \multirow[t]{2}{*}{$\begin{array}{c}\text { Number } \\
\text { of } \\
\text { Sands }\end{array}$} & \multicolumn{3}{|c|}{$\begin{array}{l}\text { Discrete Sandstone } \\
\text { thickness-meters }\end{array}$} \\
\hline & & & & $0-15$ & $15-30$ & $>30$ \\
\hline \multicolumn{7}{|l|}{ PLIOCENE-MIOCENE } \\
\hline Easi Morzhovoi Bay & 455 & $45 \%$ & 34 & 34 & 0 & 0 \\
\hline Wesı Morzhovoi Bay & 1,221 & $92 \%$ & 29 & 26 & 2 & 1 \\
\hline \multicolumn{7}{|l|}{ MIOCENE } \\
\hline Aliaksin Peninsula & 499 & $100 \%$ & 12 & 8 & 3 & 1 \\
\hline Southeast Bear Lakc & 1,175 & $96 \%$ & 31 & 22 & 7 & 2 \\
\hline Black Lake & 2,152 & $61 \%$ & 34 & 27 & 2 & 5 \\
\hline Milky River & 2,658 & $89 \%$ & 72 & 57 & 14 & 1 \\
\hline White Bluff & 948 & $38 \%$ & 19 & 18 & 1 & 0 \\
\hline \multicolumn{7}{|l|}{ OLIGOCENE-EOCENE } \\
\hline Beaver Bay & 1,936 & $61 \%$ & 44 & 44 & 0 & 0 \\
\hline Beaver Bay East* & 2,798 & $25 \%$ & Unknown & $?$ & 4 & 1 \\
\hline Lcithand Bay-Balboa Bay & 1,668 & $.78 \%$ & 4 & 4 & 0 & 0 \\
\hline Walcrfall Point* & 378 & $53 \%$ & Unknown & All & 0 & 0 \\
\hline \multicolumn{7}{|c|}{ EOCENE(?) OR PALEOCENE(?) } \\
\hline Heren I & 146 & $66 \%$ & 6 & 6 & 0 & 0 \\
\hline Heren II & 172 & $43 \%$ & 13 & 13 & 0 & 0 \\
\hline Average percent & & $62.8 \%$ & & & & \\
\hline Tolals & 16,206 & & 298 & 240 & 29 & 10 \\
\hline
\end{tabular}

*Not all the sands in this section were measured; thus percentage of sandstone is estimated. 
TABLE 3- POROSITY AND PERMEABILITY ANALYSES

(Analyses by Chemical and Geological Laboratorics of Alaska, fnc.)

\section{Sample Number}

Waterfall Point: Stepovak Formation ${ }^{2}$

2-GB-77

4-GB-77

9.GB-77

13.GB.77

Milky River: Bear Lake Formation

29-GB-77

30-GB- 77

39-GB-77

95.WL-77

84-WL-77

93-WL.77

A $72-W L-77$

76-WL-77

77.WL-77

78-WL-77

90-WL-77

East Morzhovoi Bay: Tachilni Formation

52-GB.77

$56-G B \cdot 77$

Gull Point on Herendeen Bay: Chignik Formations

58-GB. 77

59-GB-77

$60-6 B \cdot 77$

$61-\mathrm{GB}-77$

Bold Bluff Point on Herendeen Bay: Naknek Formation 64-GB-77

66-GB-77

Tolstoi Formationa NE $1 / 1$, Sec. 6, T. 54 S., R. 76 W.

$71 \cdot \mathrm{GB}-77$

$72-G B-77$

Gas Rocks (sce location map)

73-GB-77

2.8

15.1

13.6

6.2
Permeability

(mD)

0.04

0.60

0.04

0.06

0.32

2.61

1,83

53,00

0.86

unconsolidated sand

0.26

0.05

72.00

10.00

unconsolidated sand

2.00

2.42

0.21

0.21

0.10

0.09

0.02

0.33

0.09

0.02

0.11

2.87

1.17

5.00

${ }^{\mathrm{a}}$ Burk (1965) 
Sample Number

Lef thand Bay: Stepovak Formation ${ }^{\text {a }}$ 20-1P.77

Heren I: Tolstoi Formationa

28.1P.77

$31 \cdot 19.77$

$32-19-77$

34- $1 P-77$

$35-19.77$

Heren II: Unnamed formation

$$
\begin{aligned}
& 38-1 P-77 \\
& 39-1 P-77 \\
& 43.1 P-77 \\
& 46.1 P-77 \\
& 51.1 P .77 \\
& 52-1 P-77 \\
& 53.1 P-77
\end{aligned}
$$

Mother Goose Area: Cretaceous 64-1P.77

Mother Goose Area: Tertiary 67.19.77

White Bluff: Bear Lake Formation 71-WL-77

Beaver Bay: Stepovak Formationa 33-WL-77

24-WL-77

23.WL-77

40-WL-77

30-WL-77

Black Lake: Bear Lake Formation

18.WL-77

12.WL-77

14WL-77

20-WL-77

Aliaksin Peninsula: Bear Lake Formation

46.WL-77

49.WL.77

S. E. Bear Lake: Bear Lake Formation 36-.jM-77
Effective Porosity

$\%$

Permeability

$(\mathrm{mD})$

1.7

0.02

11.2

0.82

11.5

0.42

0.23

0.43

0.21

7.5

11.8

0.23

0.48

0.11

0.06

0.08

0.78

8.50

11.7

1.7

0.01

6.8

0.02

4.2

0.06

19.6

16.3

15.0

90.00

3.79

0.07

0.03

15.3

0.05

1.7

5.6

12.5

8.7

0.21

0.18

0.06

2.4

2.28

16.0

unconsolidated sand

10

6.6

1.04

aBurk (1965) 
TABLE 4--ORGANIC GEOCHEMICAL DATA (Analyses by Geochem Laboratories, Inc., Houston, Texas)

\begin{tabular}{|c|c|}
\hline $\begin{array}{l}\text { Sample } \\
\text { Number }\end{array}$ & $\begin{array}{c}\text { Organic Carbon } \\
\text { Content } \\
\text { (Weight Percent) }\end{array}$ \\
\hline $06-G B-77$ & $0.42(0.44)$ \\
\hline $10 \cdot \mathrm{GB}-77$ & 0.33 \\
\hline 14-GB-77 & 0.26 \\
\hline $16-\mathrm{GB} \cdot 77$ & 0.58 \\
\hline $18-G B-77$ & 0.42 \\
\hline 21-GB.77 & $0.43(0.46)$ \\
\hline $24 \mathrm{~GB}-77$ & 0.62 \\
\hline $26 \cdot G B \cdot 77$ & 0.25 \\
\hline $33-G B-77$ & 0.37 \\
\hline $35-G B-77$ & $0.53(0.56)$ \\
\hline $37-G B-77$ & 0.67 \\
\hline $40-G B-77$ & 0.96 \\
\hline 43-GB-77 & 0.35 \\
\hline $45-G B-77$ & 0.69 \\
\hline 48-GB-77 & $0.28(0.30)$ \\
\hline $63 \cdot G B-77$ & 0.82 \\
\hline $68-G B-77$ & 0.18 \\
\hline $70-\mathrm{GB} \cdot 77$ & 1.24 \\
\hline $76-\mathrm{GB} \cdot 77$ & 0.72 \\
\hline $78-G B-77$ & $0.79(0.78)$ \\
\hline $80 \cdot G B-77$ & 0.60 \\
\hline $82-G B-77$ & 0.69 \\
\hline $84 . G B \cdot 77$ & 0.69 \\
\hline $86 \cdot G B \cdot 77$ & 0.62 \\
\hline $88 \cdot G B \cdot 77$ & $0.71(0.68)$ \\
\hline $90-G B-77$ & 0.80 \\
\hline 8.WL.77 & 0.15 \\
\hline 11.WL.77 & 0.14 \\
\hline 22-WL-77 & 1.23 \\
\hline $26-W L-77$ & $0.87(0.86)$ \\
\hline 29-WL-77 & 1.17 \\
\hline $33 \mathrm{~A} \cdot$ WL -77 & 1.91 \\
\hline 35-WL-77 & 1.94 \\
\hline $38-W L-77$ & 1.10 \\
\hline 39.WL.77 & $3.94(3.91)$ \\
\hline $42-W L \cdot 77$ & 0.39 \\
\hline 43.WL. 77 & 0.18 \\
\hline
\end{tabular}

\begin{tabular}{|c|c|c|c|}
\hline & & & \\
\hline Typed & $\left.T A\right|^{b}$ & $\begin{array}{l}\text { Total } \\
\text { (ppm) }\end{array}$ & $\begin{array}{l}\text { Asphaltenes } \\
\text { (ppm) }\end{array}$ \\
\hline$H ; W ; A m$ & 2- to $\underline{2}$ & 179 & 106 \\
\hline $\mathrm{H} ; \mathrm{C} ; \mathrm{Am}-\mathrm{W}$ & 2 to $2+$ & 148 & 97 \\
\hline $\mathrm{H} ; W ; A m-C$ & $\underline{2}+\operatorname{tos} 3$. & 483 & 380 \\
\hline $\mathrm{H} ; \mathrm{Am} ; \mathrm{W}(\mathrm{C})$ & 2. to $\underline{2}$ & 272 & 81 \\
\hline $\mathrm{Am} ; \mathrm{H} ; \mathrm{C}$ & 2. 102 & 276 & 91 \\
\hline $\mathrm{H} ; W \cdot \mathrm{C} ; \mathrm{Am}$ & 2. $10 \underline{2}$ & 266 & 76 \\
\hline$A m \cdot H ; ; C$ & $1+$ to 2 & 382 & 98 \\
\hline $\mathrm{H} ; \mathrm{W} ; \mathrm{C}$ & 2 to $2+$ & 103 & 74 \\
\hline $\mathrm{H} ; \mathrm{Am} ; \mathrm{W}-\mathrm{C}$ & 2. $\cos 2$ & 124 & 61 \\
\hline $\mathrm{H} ; \mathrm{Am} ;-$ & $1+102-$ & 772 & 98 \\
\hline $\mathrm{H} ; W ; A m-C$ & 1 to $1+4$ & 152 & 96 \\
\hline$H_{i-i} \cdot A m \cdot C$ & 1 to $1 \pm$ & 273 & 152 \\
\hline $\mathrm{H} ; \mathrm{C} ; \mathrm{W}$ & 2. to 2 & 457 & 142 \\
\hline $\mathrm{H} ; \mathrm{W} ; \mathrm{C}$ & 2- 102 & 520 & 208 \\
\hline$H ; A m ; W$ & 2- to 2 & 298 & 152 \\
\hline$H ; A m ; W$ & 2. 102 & 246 & 111 \\
\hline$A m ; H ; W-C$ & $\underline{2}$ to $2+$ & 131 & 67 \\
\hline$A m ; H ;-$ & $\underline{2}$ to $2+$ & 200 & 88 \\
\hline$W \cdot C_{i} A m-H_{i}$ & 3. to 3 & 89 & 71 \\
\hline HCC;W;Am & 3 to $\underline{3+}$ & 55 & 38 \\
\hline W-C;H;Am & $\underline{3}$ to $3+$ & 73 & 43 \\
\hline $\mathrm{H} \cdot \mathrm{C} ; \mathrm{W} ;-$ & 3 to $3+$ & 95 & 66 \\
\hline $\mathrm{H}-\mathrm{C} ; \mathrm{W}_{i-}^{-}$ & 3 to $3+$ & 37 & 30 \\
\hline W-C;H;Am & 3 to $3+$ & 88 & 55 \\
\hline$W-C ; H ; A m$ & $\underline{3}$ to $3+$ & 85 & 52 \\
\hline W-C;H;Am & 3. $10 \underline{3}$ & 83 & 47 \\
\hline $\mathrm{H} ; \mathrm{C} ; \mathrm{Am}$ & 2. to 2 ? & 185 & 55 \\
\hline $\mathrm{H} ; \mathrm{C} ; \mathrm{Am}$ & $2 ?$ & 464 & 107 \\
\hline $\mathrm{H} ; A \mathrm{~m} ; W$ & 2. to $\underline{2}$ & 266 & 123 \\
\hline $\mathrm{H} ; \mathrm{W} ; \mathrm{Am}$ & $\underline{2}$ to $2+$ & 189 & 62 \\
\hline $\mathrm{H} ; \mathrm{Am} ; \mathrm{W}$ & $\underline{2}$ to $2+$ & 176 & 76 \\
\hline $\mathrm{H} ; \mathrm{Am} ; \mathrm{W}-\mathrm{C}$ & $2+103-$ & 107 & 60 \\
\hline $\mathrm{H} ; \mathrm{C} ; \mathrm{Am}-\mathrm{W}$ & $\underline{2}$ to $2+$ & 462 & 149 \\
\hline $\mathrm{H} ; \mathrm{Am}-\mathrm{W} ; \mathrm{C}$ & $2=102+$ & 398 & 83 \\
\hline$H ; A m ; W$ & $\underline{2}$ to $2+$ & 939 & 251 \\
\hline $\mathrm{H} ; \mathrm{W} \cdot \mathrm{C} ; \mathrm{Am}$ & 2. to 2 & 1947 & 1788 \\
\hline$H ; W ; A m$ & $2-$ to 2 & 967 & 896 \\
\hline
\end{tabular}

a. Kerogen key (in order listed): Predominant-60 to 100\%; Secondary- -20 to 40\%; Trace-1 to 20\%. $\mathrm{Al}=\mathrm{Algal}, \mathrm{Am}=$ Amorphous-Sapropel, $\mathrm{H}=\mathrm{H}$ crbaccous-Sporc/Cuticle, $W=$ Woody, $\mathrm{C}=$ Codly, $\mathrm{U}=$ Unidentificd Material. b. Scale from $1=$ unaltered to 4 = severely altered; underlined number indicates dominant rank of alteration. 


\begin{tabular}{|c|c|c|c|c|c|}
\hline \multirow{2}{*}{$\begin{array}{l}\text { Sample } \\
\text { Number }\end{array}$} & \multirow{2}{*}{$\begin{array}{c}\text { Organic Carbon } \\
\text { Content } \\
\text { (Weight Percent) }\end{array}$} & \multirow{2}{*}{\multicolumn{2}{|c|}{ Kerogen }} & \multicolumn{2}{|c|}{$C_{1 s}+$ Extract } \\
\hline & & & & $\begin{array}{l}\text { Total } \\
\text { (ppm) }\end{array}$ & $\begin{array}{l}\text { Asphaltenes } \\
\quad(p p m)\end{array}$ \\
\hline $53-$ WL-77 & 8.73 & $\mathrm{H} ; \mathrm{Am} ; \mathrm{W}$ & 1 to $1+$ & 2984 & 1215 \\
\hline $61-W L-77$ & 3.22 & $\mathrm{H} ; \mathrm{W} ; \mathrm{C}$ & $1+102$ & 1372 & 1146 \\
\hline $65 \cdot$ WL.77 & $1.21(1.22)$ & $\mathrm{H} ; \mathrm{W} ; \mathrm{Am}$ & 2. to 2 & 372 & 200 \\
\hline 67. WL. 77 & 0.69 & $\mathrm{H} ; A m ; \mathrm{C}$ & 2- to 2 & 266 & 143 \\
\hline 69-WL-77 & 0.14 & $\mathrm{H} ; \mathrm{C} ; \mathrm{Am}$ & $\underline{2}-102$ & 98 & 54 \\
\hline 74-WL-77 & 0.67 & $\mathrm{H} ; \mathrm{W} ; \mathrm{Am}-\mathrm{C}$ & $\underline{\underline{2}}$ to 2 & 141 & 86 \\
\hline 80-WL-77 & 0.82 & $\mathrm{H} ; \mathrm{W} ; \mathrm{Am}(\mathrm{C})$ & $\underline{2}-$ to 2 & 270 & 86 \\
\hline 83-WL.77 & $7.88(1.89)$ & $H ; W ; A m$ & 2. 102 & 619 & 259 \\
\hline 85-WL-77 & 0.87 & $\mathrm{H} ; \mathrm{W} ; \mathrm{Am}-\mathrm{C}$ & 2. 102 & 317 & 147 \\
\hline 89.WL.77 & 0.66 & $\mathrm{H} ; \mathrm{Am} ; \mathrm{W}$ & 2. 102 & 293 & 144 \\
\hline $92-W L-77$ & 0.57 & $\mathrm{H}, \mathrm{C} ; \mathrm{Am}-\mathrm{W}$ & 2 & 628 & 147 \\
\hline $97 \cdot$ WL.77 & 0.85 & $\mathrm{H} ; \mathrm{Am} ; \mathrm{W}$ & $1+102$ & 273 & 119 \\
\hline 100 WL -77 & $0.57(0.56)$ & $\mathrm{H} ; \mathrm{Am} ; \mathrm{W} C \mathrm{C}$ & $1+102-$ & 345 & 196 \\
\hline 102.WL.77 & 0.72 & $H ; W ; A m \cdot C$ & $\underline{2}$ to 2 & 343 & 98 \\
\hline 104-WL-77 & 0.26 & $\mathrm{H} ; \mathrm{W}-\mathrm{C} ; \mathrm{Am}$ & $\underline{2} \cdot 102$ & 127 & 41 \\
\hline $10-1 P .77$ & 0.32 & Am;H-W;- & $\overline{2}$ - to $\underline{2}$ & 93 & 23 \\
\hline $13-18-77$ & 0.23 & $\mathrm{H} ; \mathrm{Am} ; \mathrm{W}$ & 2. to $\overline{2}$ & 156 & 59 \\
\hline $14-1 P .77$ & $0.54(0.54)$ & $A m ; H ; W$ & $\underline{2}$ to 2 & 375 & 73 \\
\hline $17-19 \cdot 77$ & 0.38 & $\mathrm{H}-\mathrm{W} ; \mathrm{Am} ; \mathrm{C}$ & $\underline{2}$ to 2 & 180 & 72 \\
\hline $19-1 P-77$ & 0.46 & $\mathrm{H} ; \mathrm{Am} ; \mathrm{W} \cdot \mathrm{C}$ & 2 & 241 & 77 \\
\hline $22-1 P \cdot 77$ & 0.86 & $\mathrm{H} ; \mathrm{Am} ; \mathrm{W} \cdot \mathrm{C}$ & 2. 102 & 196 & 60 \\
\hline $25 \cdot 1 P-77$ & 0.39 & $H ; W ; A m-C$ & $2-10 \underline{2}$ & 331 & 163 \\
\hline $37-1 P-77$ & $1.08(1.02)$ & $\mathrm{H} ; \mathrm{W} ; \mathrm{Am}$ & 2. $10 \underline{2}$ & 646 & 247 \\
\hline $42-1 P-77$ & 0.98 & $H ; A m ; W$ & 2. $10 \underline{\underline{2}}$ & 927 & 701 \\
\hline $45-1 P-77$ & 2.29 & $\mathrm{H} ; \mathrm{Am} ; \mathrm{W}$ & 2. to $\underline{\underline{2}}$ & 623 & 435 \\
\hline $50-1 P .77$ & 2.03 & $H ; A m ; W$ & $2-10 \underline{2}$ & 313 & 133 \\
\hline $63-1 P-77$ & 1.11 & W-C;H;- & $\underline{3}$ to $\overline{3}+$ & 83 & 45 \\
\hline $66-1 P-77$ & $0.19(0.18)$ & $\mathrm{H} \cdot \mathrm{W} ; ; \mathrm{C}$ & 2 to $2+$ & 223 & 167 \\
\hline 38-IP-77 & 0.41 & $H ; W ; C$ & $\underline{2}$ to $\overline{2}$ & 125 & 76 \\
\hline 41-JM-77 & 0.16 & $\mathrm{H} ; A m ; W \cdot C$ & 2. to $\underline{2}$ & 227 & 169 \\
\hline 46.JM-77 & 0.98 & $H ; W ; A m$ & $2102 t$ & 282 & 186 \\
\hline
\end{tabular}

a. Kerogen key (in order listed): Predominant -60 to 100\%; Secondary-20 to 40\%; Trace-1 to $20 \%$. $\mathrm{Al}=\mathrm{A} \mid \mathrm{gal}, \mathrm{Am}=$ Amorphous-Sapropel, $\mathrm{H}=$ Herbaceous-Spore $/$ Cuticle,$W=$ Woody, $C=$ Coaly, $U=$ Unidentified Material.

b. Scale from $1=$ unaltered to $4=$ severely altered; underlined number indicates dominant rank of alteration. 
TABLE 5-PETROGRAPHIC DATA

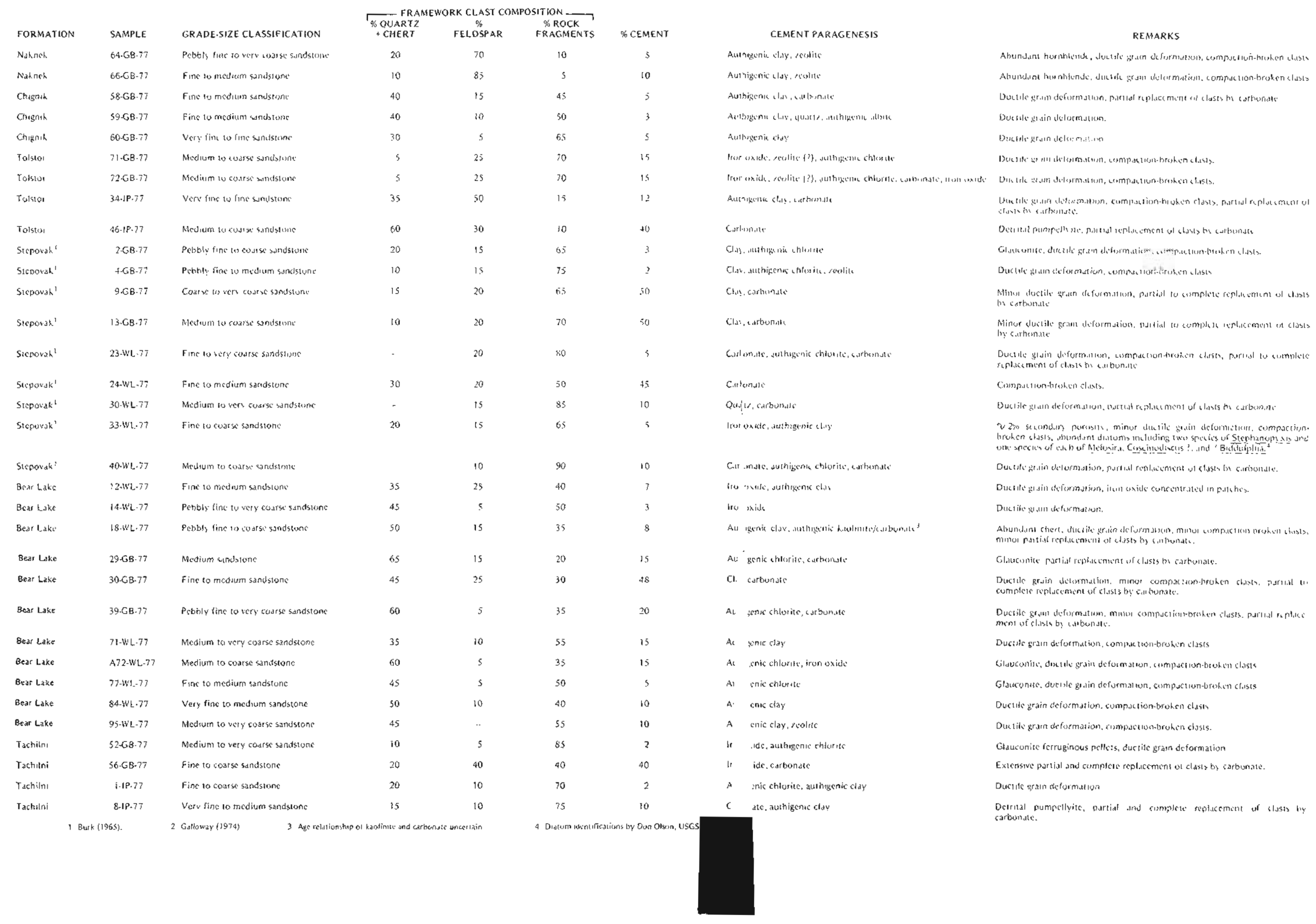




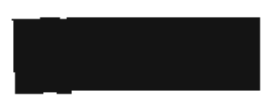




\section{TABLE 6-GEOCHEMICAL ANALYSES}

Stream-scdiment samples were analyzed for gold, silyer, copper, lead, zinc, molybdenum, and tin. The results are in parts per million.

\begin{tabular}{|c|c|c|c|c|c|c|c|}
\hline Sample No. & Gold & Silver & Copper & Lead & Zinc & Molybdenum & Antimony \\
\hline $1-1 M-77$ & 0.24 & 0.00 & 19.2 & 3.0 & 43 & 0 & 0 \\
\hline 2-JM-77 & 0.10 & 0.00 & 17.8 & 3.8 & 44 & 0 & 0 \\
\hline $3 \cdot 1 \mathrm{M}-77$ & 0.08 & 0.00 & 27.7 & 12.4 & 33 & 0 & 0 \\
\hline 4-JM-77 & 0.14 & 1.00 & 19.6 & 7.1 & 73 & 0 & 0 \\
\hline $5-1 M-77$ & 0.20 & 0.00 & 24.6 & 24.0 & 78 & 0 & 0 \\
\hline $6 \cdot J M \cdot 77$ & 0.10 & 0.00 & 19.6 & 3.1 & 51 & 0 & 0 \\
\hline $7 . J M-77$ & 0.08 & 0.00 & 16.2 & 7.8 & 53 & 0 & 0 \\
\hline $8-1 M-77$ & 0.04 & 0.00 & 16.0 & 3.7 & 65 & 0 & 0 \\
\hline $9-1 \mathrm{M}-77$ & 0.06 & 0.00 & 16.6 & 3.1 & 58 & 0 & 0 \\
\hline $10-1 \mathrm{M} \cdot 77$ & 0.12 & 0.00 & 23.0 & 2,0 & 56 & 0 & 0 \\
\hline $11 . / M-77$ & 0.14 & 0.00 & 19.4 & 0.0 & 73 & 0 & 0 \\
\hline $12 \cdot \int M-77$ & 0.24 & 0.04 & 13.8 & 56.0 & 56 & 0 & 35 \\
\hline $13 \cdot 3 M-77$ & 0.18 & 0.00 & 10.9 & 11.5 & 32 & 0 & 0 \\
\hline $14 \cdot 3 \mathrm{M} \cdot 77$ & 0.24 & 0.00 & 16.3 & 0.6 & 38 & 0 & 0 \\
\hline $15-J M-77$ & 0.34 & 0.05 & 19.8 & 0.0 & 38 & 0 & 0 \\
\hline 16-ןM-77 & 0.34 & 0.07 & 18.0 & 3.1 & 48 & 0 & 0 \\
\hline $78-1 M-77$ & 0.12 & 0.00 & 11.1 & 8.6 & 45 & 0 & 0 \\
\hline 19.JM-77 & 0.24 & 0.00 & 22.2 & 12.4 & 52 & 0 & 0 \\
\hline 20-JM-77 & 0.30 & 0.11 & 4.3 & 1.1 & 27 & 0 & 0 \\
\hline $21 \cdot . \mathrm{M}-77$ & 0.10 & 0.00 & 17.4 & 1.3 & 60 & 0 & 0 \\
\hline $22 . J M-77$ & 0.16 & 2.84 & 19.7 & 874 & 68 & 0 & 526 \\
\hline 23-JM-77 & 0.14 & 0.02 & 12.0 & 7.8 & 58 & 0 & 0 \\
\hline 24-JM-77 & 0.12 & 0.00 & 17.7 & 4.6 & 50 & 0 & 0 \\
\hline $25 \cdot J M-77$ & 0.24 & 0.00 & 16.9 & 2.7 & 59 & 0 & 0 \\
\hline $26-J M-77$ & 0.24 & 0.00 & 19.8 & 1.7 & 68 & 0 & 0 \\
\hline 27-JM-77 & 0.34 & 0.00 & 18.2 & 6.9 & 60 & 0 & 0 \\
\hline 28. JM-77 & 0.26 & 0.00 & 15.7 & 13.1 & 32 & 0 & 0 \\
\hline 29.JM-77 & 0.20 & 0.00 & 17.7 & 1.9 & 27 & 0 & 0 \\
\hline 30-JM-77 & 0.16 & 0.00 & 12.4 & 16.0 & 23 & 0 & 0 \\
\hline $31 \cdot M-77$ & 0.16 & 0.03 & 15.7 & 1.7 & 40 & 0 & 0 \\
\hline $32-J M-77$ & 0.26 & 0.00 & 15.2 & 0.8 & 29 & 0 & 0 \\
\hline $33-J M-77$ & 0.14 & 0.00 & 36.8 & 14.8 & 40 & 0 & 0 \\
\hline 48-JM-77 & 0.14 & 0.28 & 49.2 & 51.7 & 153 & 0 & 0 \\
\hline 49-JM-77 & 0.32 & 0.22 & 57.6 & 31.2 & 132 & 0 & 0 \\
\hline $50-19-77$ & 0.28 & 0.22 & 21.4 & 13.8 & 45 & 0 & 0 \\
\hline 52.JM-77 & 0.78 & 0.76 & 46.2 & 267.0 & 610 & 0 & 46 \\
\hline $53-19-77$ & 0.24 & 0.00 & 67.3 & 8.3 & 85 & 0 & 0 \\
\hline $54-\int M-77$ & 0.24 & 0.00 & 25.7 & 75.3 & 55 & 0 & 0 \\
\hline $55 . J M-77$ & 0.38 & 0.00 & 37.3 & 8.3 & 42 & 2 & 0 \\
\hline 56-JM-77 & 0.36 & 0.00 & 51.3 & 4.0 & 29 & 2 & 0 \\
\hline
\end{tabular}




\begin{tabular}{|c|c|c|c|c|c|c|c|}
\hline Sample No. & Gold & Silver & Copper & Lead & Zinc & Molybdenum & Antimony \\
\hline 1-WL-77 & 0.46 & 0.05 & 33.2 & 3.2 & 209 & 0 & 0 \\
\hline 2-WL. 77 & 0.44 & 0.00 & 19.3 & 0.0 & 177 & 0 & 0 \\
\hline 3-WL.77 & 0.00 & 0.00 & 30.2 & 3.8 & 44 & 0 & 0 \\
\hline $\mathrm{A} 1 \cdot 1 \mathrm{~B}-77$ & 0.10 & 0.00 & 18.5 & 8.2 & 75 & 0 & 0 \\
\hline A2-JB-77 & 0.24 & 0.00 & 21.4 & 3.0 & 66 & 0 & 0 \\
\hline $\mathrm{A} 3 \cdot \mathrm{J} \cdot \mathrm{B}-77$ & 0.04 & 0.02 & 17.8 & 1.4 & 66 & 0 & 0 \\
\hline A4. $1 \mathrm{~B}-77$ & 0.02 & 0.00 & 7.1 & 3.2 & 48 & 0 & 0 \\
\hline A5-JB-77 & 0.00 & 0.00 & 20.0 & 11.0 & 66 & 0 & 0 \\
\hline A6-JB-77 & 0.29 & 0.06 & 13.6 & 1.8 & 143 & 0 & 0 \\
\hline A7-JB-77 & 0.34 & 0.00 & 19.0 & 1.0 & 228 & 0 & 0 \\
\hline A8-JB-77 & 0.19 & 0.00 & 11.7 & 0.6 & 317 & 0 & 0 \\
\hline A9-JB-77 & 0,04 & 0.00 & 7.3 & 0.5 & 73 & 0 & 0 \\
\hline A $10-1 B-77$ & 0.34 & 0.00 & 21.4 & 2.3 & 63 & 0 & 0 \\
\hline $6-1 B .77$ & 0.06 & 0.12 & 38.3 & 23.7 & 146 & 0 & 0 \\
\hline 7.18 .77 & 0.08 & 0.06 & 43.9 & 60.3 & 0 & & \\
\hline $24 \mathrm{JB} \cdot 77$ & 0,04 & 0.06 & 29.5 & 0.7 & 64 & 0 & 0 \\
\hline 25.18 .77 & 0.14 & 0.00 & 18.5 & 1.9 & 47 & 0 & 0 \\
\hline $29 \cdot 18-77$ & 0.06 & 0.00 & 34.0 & 6.9 & 71 & 1 & 0 \\
\hline 30. B. 77 & 0.00 & 0.00 & 21.8 & 3.3 & $\$ 2$ & 0 & 0 \\
\hline 31.18 .77 & 0.12 & 0.00 & 23.3 & 4.3 & 62 & 0 & 0 \\
\hline $32-J \mathrm{~B}-77$ & 0.10 & 0.00 & 17.4 & 2.6 & 41 & 0 & 0 \\
\hline $33-1 \mathrm{~B}-77$ & 0.00 & 0.00 & 16.2 & 0.0 & 123 & 0 & 0 \\
\hline $34-18.77$ & 0.04 & 0.00 & 27.9 & 0.7 & 186 & 0 & 0 \\
\hline $35 \cdot 18 \cdot 77$ & 0.12 & 0.00 & 30.3 & 0.8 & 0.8 & 0 & 222 \\
\hline $36 \cdot 18 \cdot 77$ & 0.06 & 0.00 & 27.6 & 0.0 & 258 & 0 & 0 \\
\hline 37.18 .77 & 0.06 & 0.00 & 37.2 & 2.1 & 97 & 0 & 0 \\
\hline $38-\mid B-77$ & 0.12 & 0.00 & 23.0 & 1.6 & 65 & 0 & 0 \\
\hline $39 \cdot 1 \mathrm{~B} \cdot 77$ & 0.14 & 0.00 & 27.1 & 1.6 & 114 & 0 & 0 \\
\hline $40-18 \cdot 77$ & 0.04 & 0.00 & 30.6 & 6.6 & 56 & 0 & 0 \\
\hline 41.JB-77 & 0.32 & 0.00 & 24.3 & 3.1 & 143 & 0 & 0 \\
\hline $42 \cdot \mid B \cdot 77$ & 0.12 & 0.00 & 17.8 & 3.6 & 82 & 0 & 0 \\
\hline $43-18-77$ & 0.37 & 0.00 & 15.2 & 3.3 & 108 & 0 & 0 \\
\hline $44-18-77$ & 0.64 & 0.00 & 14.2 & 0.7 & 73 & 0 & 0 \\
\hline $45 \cdot 1 \mathrm{~B}-77$ & 0.50 & 0.00 & 37.9 & 5.9 & 72 & 0 & 0 \\
\hline $46 \cdot 18-77$ & 0.48 & 0.00 & 99.9 & 12.7 & 111 & 0 & 0 \\
\hline $47-18-77$ & 0.38 & 0.00 & 24.8 & 1.7 & 53 & 0 & 0 \\
\hline $48-\mathrm{J}-77$ & 0.42 & 0.00 & 12.3 & 0.0 & 52 & 0 & 0 \\
\hline 49-ןB-77 & 0.20 & 0.00 & 15.6 & 0.0 & 48 & 0 & 0 \\
\hline $98-J B-77$ & 0.42 & 0.00 & 22.7 & 0.3 & 36 & 0 & 0 \\
\hline 99.18 .77 & 0.28 & 0.00 & 21.4 & 0.4 & 38 & 0 & 0 \\
\hline 100-JB-77 & 0.14 & 0.00 & 20.2 & 0.0 & 2.8 & 0 & 0 \\
\hline 101-JB-77 & 0.36 & 0.00 & 25.7 & 0.0 & 27 & 0 & 0 \\
\hline $102-J \mathrm{~B}-77$ & 0.30 & 0.00 & 14.2 & 0.0 & 27 & 0 & 0 \\
\hline $103-1 B-77$ & 0.40 & 0.00 & 24.7 & 2.6 & 58 & 0 & 0 \\
\hline $104-18.77$ & 0.44 & 0.00 & 57.3 & 0.7 & 57 & 0 & 0 \\
\hline
\end{tabular}




\begin{tabular}{|c|c|c|c|c|c|c|c|}
\hline Sample No. & Gold & Silver & Copper & Lead & Zinc & Molybdenuns & Antimony \\
\hline $105 \cdot 18-77$ & 0.44 & 0.00 & 26.5 & 2.1 & 63 & 0 & 0 \\
\hline 106-JB-77 & 0.48 & 0.00 & 17.4 & 0.0 & 38 & 0 & 0 \\
\hline 55.1 P.77 & 0.66 & 14.90 & 2470.0 & 3770.0 & 8700 & 1 & 0 \\
\hline $55-1 P-77$ & 2.74 & 13,50 & 1060.0 & 2190.0 & 3300 & 0 & 0 \\
\hline 77-SWH-02A & 0.22 & 0.00 & 28.8 & 9.8 & 53 & 3 & 0 \\
\hline 77-SWH-03A & 0.53 & 0.00 & 8.5 & 5.2 & 19 & 6 & 0 \\
\hline 77.SWH-04A & 0.44 & 0.00 & 4.6 & 6.7 & 137 & 0 & 0 \\
\hline 77-SWH-OSA & 0.44 & 0.06 & 19.6 & 47.6 & 40 & 0 & 0 \\
\hline 77-SWH-14 & 0.24 & 0.00 & 22.8 & 4.2 & 97 & 0 & 0 \\
\hline $54-19-77$ & 0.13 & 0.00 & 61.4 & 22.7 & 133 & 0 & 0 \\
\hline S6-IP.77 & 0.99 & 5.44 & 390.0 & 747.0 & 380 & 0 & 0 \\
\hline $57.1 P .77$ & 0.23 & 0.00 & 32.3 & 10.0 & 43 & () & 0 \\
\hline $58-18-77$ & 0.15 & 0.00 & 43.9 & 23.6 & 64 & 0 & 0 \\
\hline $59-\mid P-77$ & 0.22 & 0.00 & 16.8 & 7.1 & 58 & 0 & 0 \\
\hline $60-4$ P.77 & 0.33 & 0.00 & 21.8 & 3.6 & 62 & 0 & 0 \\
\hline $61-\{P-77$ & 0.20 & 0.00 & 15.3 & 1.2 & 49 & 0 & 0 \\
\hline $150-J B \cdot 77$ & 0.17 & 0.00 & 27.7 & 7.9 & 75 & () & 0 \\
\hline $151 . J \mathrm{~B} .77$ & 0.16 & 0.00 & 26.4 & 3.9 & 79 & 0 & 0 \\
\hline 152.$\} \mathrm{B}-77$ & 0.39 & 0.05 & 30.3 & 11.9 & 90 & () & 0 \\
\hline $153 \cdot 1 \mathrm{~B} \cdot 77$ & 0.32 & 0.11 & 10.7 & 16.8 & 157 & 0 & 0 \\
\hline $154 . \mid \mathrm{B}-77$ & 0.40 & 0.11 & 41.9 & 20.1 & 51 & 2 & 0 \\
\hline 155-JB-77 & 0.39 & 0.25 & 50.0 & 37.3 & 224 & 1 & 0 \\
\hline $156-\mathrm{J} \mathrm{B}-77$ & 0.35 & 0.00 & 21.2 & 4.1 & 68 & 0 & 0 \\
\hline 157.J8-77 & 0.22 & 0.00 & 30.4 & 7.1 & 88 & 0 & 0 \\
\hline $158 \cdot 18-77$ & 0.30 & 0.00 & 22.6 & 5.0 & 67 & () & 0 \\
\hline
\end{tabular}


TABLE 7-PALYNOLOGY DETERMINATIONS (Analyses by Anderson, Warren and Associatcs, Inc.)

Fossil asscmblages: $A=$ abundant, $C=$ common, $F=$ frequent, and $\mathrm{R}=$ rare.

$26-19 \cdot 77$

Gymnosperm pollen (A), Osmundacidites sp. (R), LYcopodiumsporites sp. (R), Taxodiaccac (R).

Deflandrea denticulata (F), Palacocystodinium golzowense (R), Spiniferites spp. $(R)$.

AGE: $\quad \begin{aligned} & \text { Palcogenc (Paleocencearly } \\ & \text { Eocene) }\end{aligned}$

ENVIRONMENT: Marine.

27-IP-77

Gymnosperm pollen (F).

Deflandrea denticulata (R), Spiniferites septatus (R), Spinifcrites spp. (R).

$\begin{array}{ll}\text { AGE: } & \text { Paleogenc (Palcocene) } \\ \text { ENVIRONMENT: } & \text { Marine. }\end{array}$

29-1P.77

Gymnosperm pollen (C).

Deflandrca denticulata $(R)$, Palaeocystodinium golzowensc (F), Spiniferites spp. (R).

$\begin{array}{ll}\text { AGE: } & \text { Palcogene (Paleocene-carly } \\ & \text { Eacenc) } \\ \text { ENVIRONMENT: } & \text { Marinc }\end{array}$

33-1P-77

Gymnosperm polten (F).

Deflandrea denticulata (R), Palacocystodinium golzowense (R).

AGE: Paleogene (Palcocene-early Eocene)

ENVIRONMENT: Marine.

44-IP-77

Gymnosperm pollen (F), Betulaceae (R).

$$
\text { AGE: Tertiary }
$$

ENVIRONMENT: Nonniarine.

\section{7-1P- 77}

Gymnosperm pollen (F), Aquilapollenites quadrilobus $(R$, reworked).

Deflandrea denticulata (R), Palaeocystodinium golzowense (R), Sirmiodinium grossi (single, reworked).

AGE: $\quad \begin{array}{ll}\text { Paleogene (Paleocene-early } \\ \end{array}$

ENVIRONMENT: Marine
49.1P.77

Gymnosperm pollen (C).

$\begin{array}{ll}\text { AGE: } & \text { Indeterminate } \\ \text { ENVIRONMENT: } & \text { Nonmarine. }\end{array}$

$62.1 \mathrm{P} .77$

No identifiable palynomorphs. Poorly preserved organ. ics, very dark brown color.
AGE:
Indelerminale
ENVIRONMENT: Probable nonmarine.

\section{$65 \cdot 1 \mathrm{P} \cdot 77$}

Lacvigatosporites sp. (R), Fungal spores (R).

$$
\begin{array}{ll}
\text { AGE: } & \text { Indeterminate } \\
\text { ENVIRONMENT: } & \text { Nonmarine. }
\end{array}
$$

52.WL. 77

Gymnosperm pollen (F), Lycopodiumsporites sp. (R), Osmundacidites (A), Laevigalosporites $5 \mathrm{p}$. (A), Alnus (R).

$$
\begin{array}{ll}
\text { AGE: } & \text { Tertiary } \\
\text { ENVIRONMENT: } & \text { Nonmarine. }
\end{array}
$$

\section{WL.77}

Gymnosperm pollen (C), Tsuga (R), Osmundacidites sp. (F), Lacvigatosporites sp. (F), Taxodiaccac (F), Juglans (R), Ulmus (R), Nyssa $(R)$.

Arcosphaeridium diktyoplokus (singlc, reworked?)

AGE: Tertiary (possible Eocene, Oligocene, or middle Miocene)

ENVIRONMENT: Probable nonmarine, warm temperate paleoclimate.

58-WL-77

Gymnosperm pollen (A), Tsuga (C), Osmundacidites sp. (A), Pterocarya (C), Juglans (F), Betulaceae (R), Alnus $(R)$, Ulmus (R), Tilia (R).
AGE: Tertiary (possible Eocene, Oligo- cene, or middle Miacene)
ENVIRONMENT: Nommarine, warm temperate paleoclimate.

\section{9-WL-77}

Gymnosperm pollen (C), Tsuga (F). Laevigatosporites so. (F), Polypodiaceac (R), Osmundacidites sp. $(R)$, Betulaceae (R), Alnus (R), Fagus [single, Tilia (single)]

AGE: Tertiary (possible Eocene, Oligocene, or middle Miocene)

ENVIRONMENT: Nonmarine, warm temperate palcoclimate. 
60.WL-77

Gymnosperm pollen (A), Tsuga (C), Laevigatosporites sp. (C), Polypod iaccae (F), Pterocarya (C), Betulaccac (F), Alnus (F), Carva (R), Ulmus (R), Nyssa (R), Tilia $(F)$, Momipites (R), Fagus (R), Boisduvalia SP. $(R)$.

AGE: Terriary (possible Eocene, Oligocene, or middle Miocene)

ENVIRONMENT: Non marine, warm temperale paleoclimatc.

\section{3-WL-77}

Gymnosperm pollen (A), Tsuga (F), Osmundacidites sp. (F), Lycopodiumsporites sp. (R), Polypodiaceac (F), Laevigatosporites sp. (F), goisduvalia $s p$. (R).

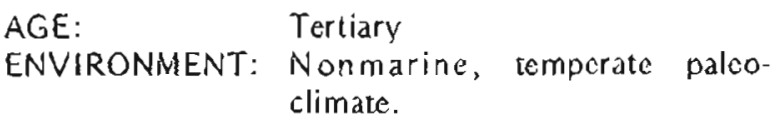

\section{WL.77}

Gymnosperm pollen (A), Tsuga (F), Laevigatosporites $\mathrm{sp},(F)$, Lycopodiumsporites $5 p .(R)$, Osmundacidites $\mathrm{sp}$. (R), Betulaceae (R), Pterocarya (R).

?Oligosphaeridium complex (single, reworked?).

$$
\begin{array}{ll}
\text { AGE: } & \text { Tertiary } \\
\text { ENVIRONMENT: } & \text { Probable nonmarine, temperate } \\
& \text { paleoclimate. }
\end{array}
$$

\section{WL.77}

Gymnosperm pollen (A), Jsuga (C), Laevigalosporites $s p$. (F), Lycopodiumsporites sp. (R), Betulaceac (R), Ulmus (R), Fagus (R).

$$
\begin{array}{ll}
\text { AGE: } & \text { Terliary } \\
\text { ENVIRONMENT: } & \text { Nanmarine, possible warm tem- } \\
& \text { perate paleoclimate }
\end{array}
$$

\section{WL.77}

Gymnosperm pollen (A), Tsuga (A), Osmundacidites sp. (R), Lycopodiumsporites sp. (R), Polypodiaceac $(R)$, Betulaceae $\{R)$, Alnus (F).

$$
\begin{array}{ll}
\text { AGE: } & \text { Tertiary } \\
\text { ENVIRONMENT: } & \begin{array}{l}
\text { Nonmarine, temperate paleo- } \\
\text { climate }
\end{array}
\end{array}
$$

\section{$76-W L-77$}

Gymnosperm pollen (C), Tsuga (C), Osmundacidites sp. $(F)$, Pterocarya $(R)$, Carya (R), Ulmus (R), Juglans $(R)$, Alnus (F), Boisduvalia sp. (R).

Micrhystridium sp. (R), Spiniferites sp. (C), Tuberculodinium vancampoae (R), Lejcunia hyalina (singlc), ?Operculodinium sp. (R).
AGE: $\quad$ Terliary (probable carly to middle Mioccne)

ENVIRONMENT: Marine (probable warm temperate palcoclimate)

TABLE 8--

\section{MACROPALEONTOLOGY DETERMINATIONS}

All macrofossils listed below are in the collections of the U.S. Geological Survey, Branch of Palcontology and Stratigraphy, Menlo Park, California. Identifications were made by Louic Marincovich.

Field locality 15.WL-77 (USCS Cenozoic loc. M7186).-Black Lake measured section, east of Black Lake near Range Peak, Chignik (B-3) Quadrangle; NW1/s, Section 3, T. 43 S., R. 60 W.; latilude $56^{\circ} 30^{\prime}$ N., longitude $158^{\circ} 43^{\prime} \mathrm{W}$. Bear Lake Formation.

Bivalves:

?Clinocardium sp.

COMMENT: ?hione sp. Specimens are all molds and casts, poorly preserved.

Field locality 16-WL.77 (USGS Cenozoic loc. M7187).-Same locality as 15-WL. 77 above but about 23 meters (75 feet) stratigraphically lower in seclion.

Bivalves: Clinocardium sp.

COMMENT: Mya sp. Mya is known in shallow water. $0.50 \mathrm{~m}$ in depth. Clinocardium in $0-200 \mathrm{~m}$ depths. Age is in. determinate.

Field localizy 47-WL-77 (USGS Conozoic loc. M7188). $-68 \mathrm{~m}$ (225 feet) above base of measured section in sea cliff, west side of Beaver Bay north of Point Aliaksin, Aliaksin Peninsula, Port Moller Quadrangle; S $1 / 2$, Section 18, T. 54 S., R. 75 W.; latitude $55^{\circ} 30^{\prime} \mathrm{N}$., longizude $167^{\circ} \mathrm{W}$.; Unga Conglomerate Member of Bear Lakc Formation.

Bivalve: Chlamys (Swiftopecten) donmilleri MacNeil

Gastropod: $\quad$ Beringius hataii MacNeil

AGE: Middlc Miocenc

ENVIRONMENT: Probably inner neritic $10-100 \mathrm{~m}$ depth): temperate marine climate. 
Field locality 103-WL-77 (USGS Cenozoic loc. M7189).-Milky River measured section, $760 \mathrm{~m}$ (2,500 fect) above base of section; on north slope of valley above headwaters of Milky River, cast of Bear Lake, Port Moller (D-1) Quadrangle; Scctions 33 and 34, T. $48 \mathrm{~S}$., R. 69 W.; latitude $55^{\circ} 59^{\prime}$ N., longitude $160^{\circ} 03^{\prime} \mathrm{W}$. Bcar Lake Formation.

Bivalves:

Gastropod:

AGE:

ENVIRONMENT: Water depth 0-50 m.

Field locality 98-WL-77 (USGS Cenozoic loc. M7190).-Same locasity as 103-WL-77 above but $843 \mathrm{~m}$ (472 feet) stratigraphically lower in Milky River section.

Bivalve: COMMENT:

?Clinocardium sp.

Age and cnvironment indelerminale.

Field locality 94-WL-77 (USGS Cenozoic loc. M7191).--Same locality as 98-WL-77 above but about 18 m (59 rect) stratigraphically lower in Milky River scction.

$\begin{array}{ll}\text { Gastropods: } & \frac{\text { Neptunea }}{\text { Kanno }} \text { (Neptunca) plafkeri } \\ & \frac{\text { Neptunea }}{\text { (Gmelin) Subspccies }} \\ \text { AGE: } & \begin{array}{l}\text { Late early Miocene to late } \\ \text { Miocene. }\end{array} \\ \text { ENVIRONMENT: } & \text { Indeterminate. }\end{array}$

Ficld locality 86-WL-77 (USGS Cenozoic loc. M7192).-Same locality as 94WL-77 above but about 82 m (270 feet) stratigraphically lower in Milky River section.

$\begin{array}{ll}\text { Gastropod: } & \text { Neptunea (Neptunea) lyrata } \\ \text { Bivalve: } & \begin{array}{l}\text { (Gmelin) subspecies } \\ \text { ?Mya sp. }\end{array} \\ \text { Plant debris: } & \begin{array}{l}\text { Carbonized leaf fragments occur } \\ \text { as very thin laminations in matrix. }\end{array} \\ \text { AGE: } & \text { Indeterminate. }\end{array}$

ENVIRONMENT: Mya inhabits depths of $0-50 \mathrm{me}$ ters in modern seas.

Field locality 105.WL-77 (USGS Cenozoic loc. M7193).-Same locality as 86.WL-77 above but about $152 \mathrm{~m}$ (500 feel) stratigraphically lower in Milky River section.

Bivalves: COMMENT:
Field locality 42-GB-77 (USGS Cenozoic loc. M7194), -Same locality as 105.WL-77 above but about $51 \mathrm{~m}$ (170 reet) stratigraphically lower in Milky River section.

$\begin{array}{ll}\text { Gastropod: } & \text { Crcpidula ungana Dall } \\ \text { AGE: } & \text { Miocene. } \\ \text { ENVIRONMENT: } & \frac{\text { Crepidula inhabits depths of }}{0-165 \text { meters in modern seas. }}\end{array}$

Field locality 42.jM-77 (USGS Cenozoic loc. M7195).-Southeast Bear Lake measured section, about $250 \mathrm{~m}$ ( $830 \mathrm{feec}$ ) above base of section; on west slope of Bear River valley, south of Bear Lake, Porl Moller (D-1) Quadrangle; Seclion 20, T. 49 S., R 70 W.; latitude $55^{\circ}$ $55^{\prime} \mathrm{N}$., longitude $106^{\circ} 10^{\prime} \mathrm{W}$. Bear Lake Formation.

$\begin{array}{ll}\text { Bivalves: } & \frac{\text { Clinocardium sp. }}{\text { ?Spisula sp. }} \\ & \text { ?Pododesmus sp. } \\ & \frac{\text { Macoma sp. }}{\text { ?Neplunea sp. }} \\ \text { Gastropod: } & \text { Age and environment indeter- } \\ \text { COMMENT: } & \text { minate. }\end{array}$

Field locality 43-1M-77 (USGS Cenozoic loc. M7196).-Same locality as 42-JM-77 above but about 23 m (75 feet) stratigraphically higher in southeast Bear Lake measured secrion.

$\begin{array}{ll}\text { Bivalves: } & \frac{\text { Clinocardium sp. }}{\text { Ostrea sp. }} \\ & \frac{\text { ?Mya sp. }}{\text { ? }} \\ & \text { ?rotothaca sp. } \\ \text { AGE: } & \text { Indeterminate. } \\ \text { ENVIRONMENT: } & \frac{\text { Ostrea (oysters) inhabit depths of }}{0-35 \text { metcrs in modern seas. }}\end{array}$

Field locality 45-JM-77 (USGS Cenozoic loc. M7197). -Same locatity as 43-JM-77 above but about 30 $\mathrm{m}$ (300 feet) stratigraphically higher in Southeast Bear Lake measured section.

Bivalve:

Gastropod:

COMMENT:

Ostrea sp.

?Turritella sp.

Age indeterminate; Ostrea (oys ters) inhabit depths of $0.35 \mathrm{mc}$ ters in modern seas.

Field locality 12-GB-77 (USGS Cenozoic loc. M7198).-Waterfall point stratigraphic section, about $108 \mathrm{~m}$ (355 feel) stratigraphically above base of section; along beach of Clarks Bay, near Waterfall Point, Port Molser (C-1) Quadrangle; Section 30, T. 53 S., R. 74 W., latitude $53^{\circ} 43^{\prime}$ N., longitude $160^{\circ} 01^{\prime}$ 'W. Stepovak Formation (8urk, 1965). 
$\begin{array}{ll}\text { Bivalves: } & \frac{\text { Macrocallista sp. }}{\text { ?Macoma sp. }} \\ \text { AGE: } & \frac{\text { Tertiary }}{\text { ENVIRONMENT: }} \\ \text { Indeterminate. }\end{array}$

Field locality 77.SWH-13 (USGS Cenozoic loc. M7199), - Same locality as 12-GB-77 above but stratigraphic position of sample was nol provided.

Sediment-filled burrow of unknown origin.

Field locality 47-GB-77 (USGS Cenozoic loc. M7200).-Measured scction at Capc Tachilni, locality 5 m (16 feet) above base of section; False Pass (D-3) Quadrangle; Section 35, T. 60 S., R. 90 W.; latitude $54^{\circ}$ $56^{\prime}$ N., longitude $162^{\circ} 52^{\prime}$ W. Tachilni Formation.

Bivalves: Vencrid-mold of interior shell reatures Clinocardium sp. Mytilus so.

AGE: $\quad$ Indetcrminate.

ENVIRONMENT: Mytilus inhabits depths of $0-40$ meters in the modern northeastcrn Pacific.

Field locality 51-GB-77 (USGS Cenozoic lor. M7201).-Same locality as 47.G8-77 above but $47 \mathrm{~m}$ (155 feet) higher stratigraphically in same section.

Bivalves:

Glycymeris sp.

Clinocardium sp.

Chlamys (Swirtopecten) cr. C. . ( . $)$ leohercleini MacNeil Venerid sp.

Gastropods: Natica (Cryptonalica) clause Broderip \& Sowerby ?Neplunea sp.

Echinoderm: Fragment of sand dollar echinoid. AGE: Pliocene

ENVIRONMENT: Cool-temperalure or colder hydroclimate.

Field locality 53-GB-77 (USGS Cenozoic loc. M7202).-Same locality as 51-GB-77 above but located stratigraphically higher and $0.2 \mathrm{~m}$ ( 2 feet) above a break in the section.

Bivalves:

Thyasira disjuncta (Gabb)

Mya sp.

AGE: Oligocene to Holocene.

ENVIRONMENT: Mya inhabils depths of 0-50 meters in the modern northeastern Pacific. Thyasira is a cool-temper. ature or colder water inhabitant.

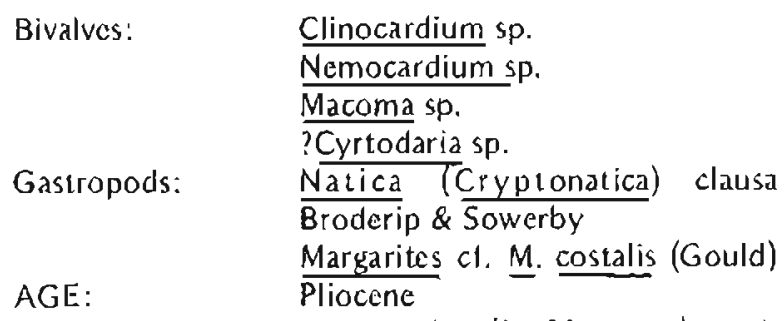

ENVIRONMENT: Inner neritic (0-100 metcrs), cooltemperalure hydroclimate.

Field locality 4-IP.77 (USGS Cenozoic loc. M7204). - Float specimens from Wost Morzhovoi Bay stratigraphic section, False Pass Quadrangle; Section 35, T. 60 S., R. $90 \mathrm{~W}$, ; latitude $54^{\circ} 56^{\circ} \mathrm{N}$., longitude $162^{\circ} 52^{\prime}$ W. Tachimi Formation.
Bivalves:
Clinocardium $s p$.
Macoma sp.
Mya (Arenomya) of. ․․ (A.) arenaria Linnacus.
AGE: $\overline{\text { Miocene }}$ or younger.
ENVIRONMENT: Inner part of inner neritic $00-50$ meters dep(h), cool-1emperature or colder hydroclimatc.

Field locality 55-GB-77 (USGS Cenozoic loc. M7203).-Same locality as 53-GB-77 above but $2.4 \mathrm{~m}(8$ feet) higher stratigraphically in the same section. 



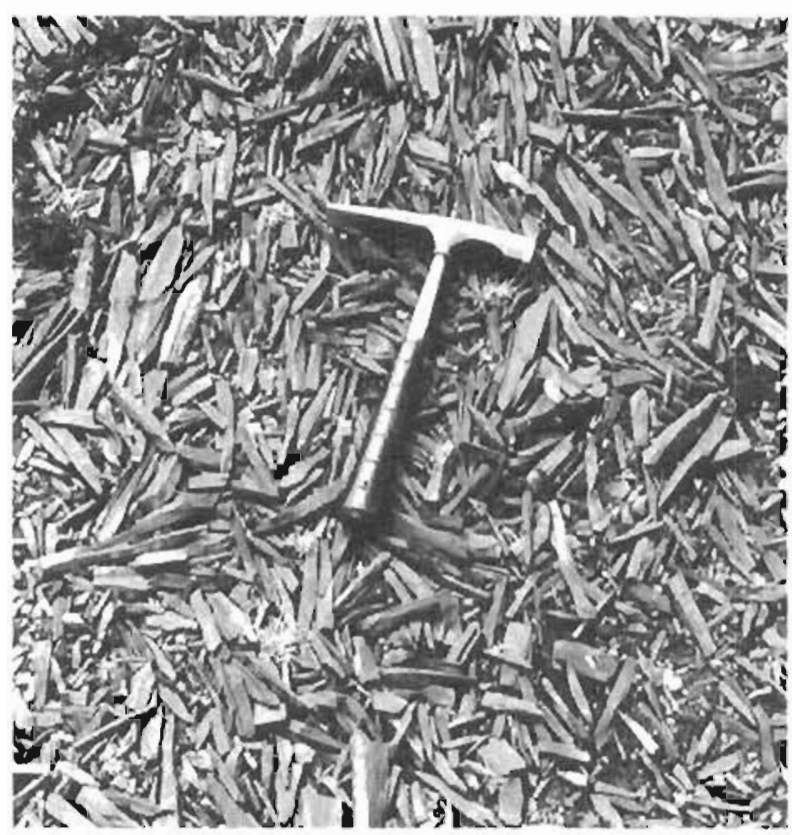

Figure 2. Splintery-weathering habit typical of Hoodoo Formation (Burk. 1965) expoșures.

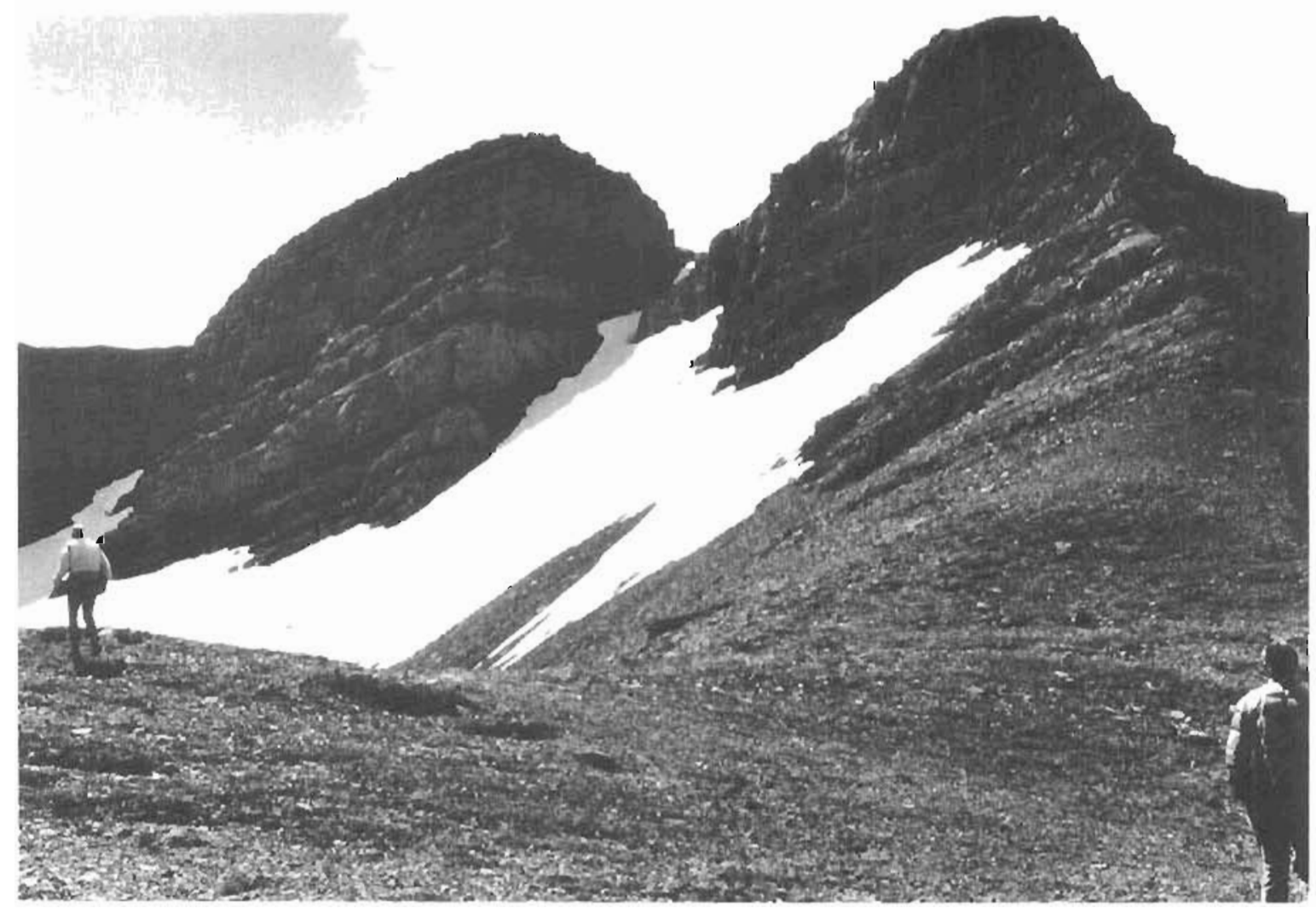

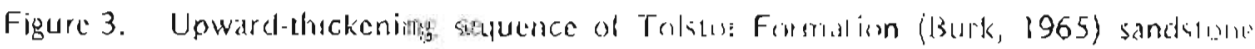
beds exposed in the norkeast cuarter of sec, 6, T. 54 S., R. 76 W. S.M. (plaic D). 


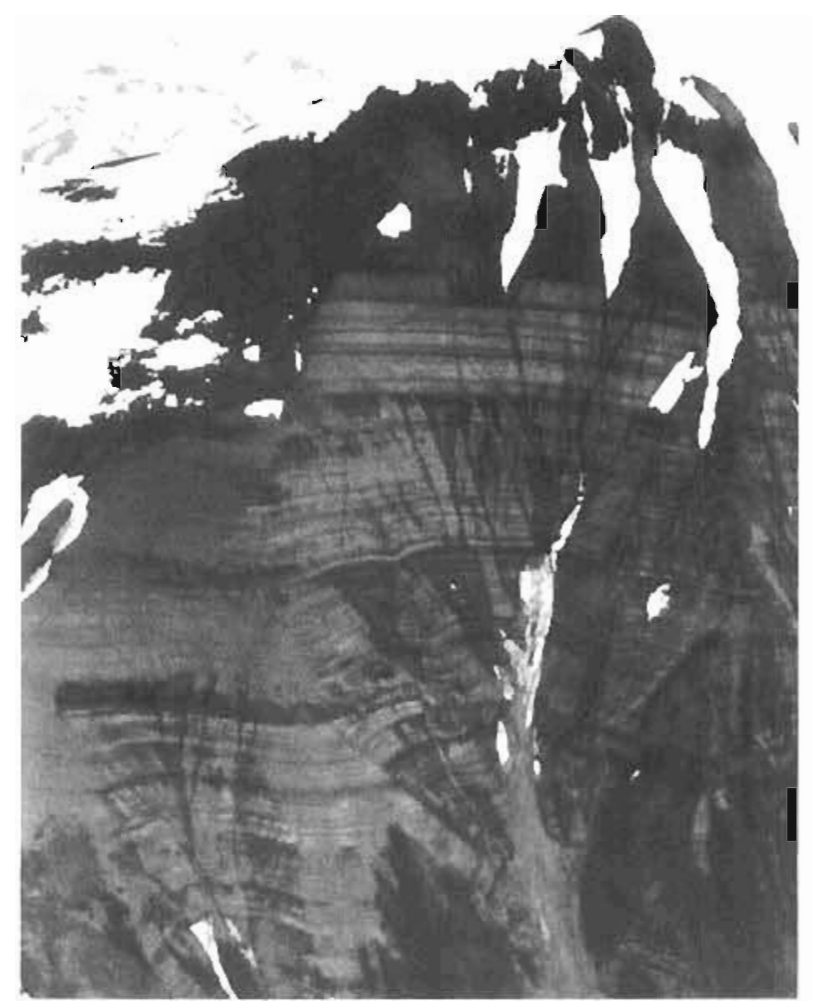

Figuic 4. Black Lake stratigraphic section exposed cast of Black Lake. The light-colored bands in this Bear Lake Formation cx. posure are generally sandstone.

Figure 5. Upper sandy unit (light-colored) of Black Lake stratigraphic section (see fig. 4).

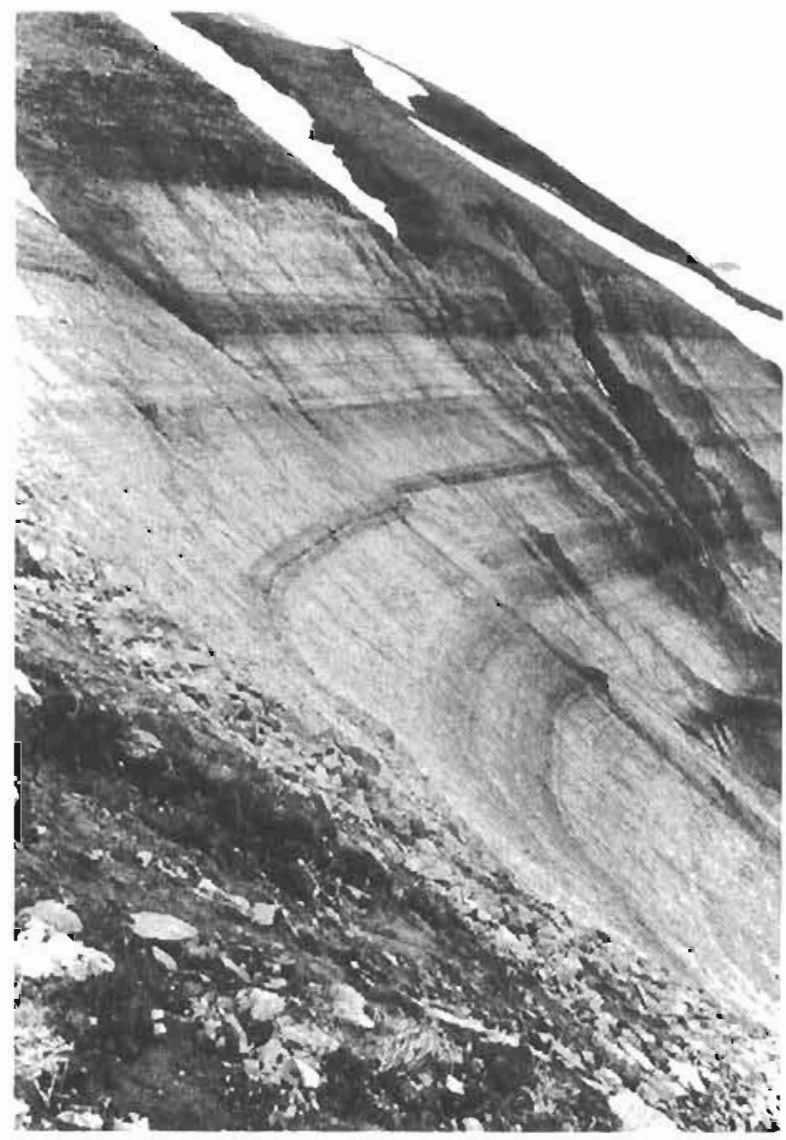




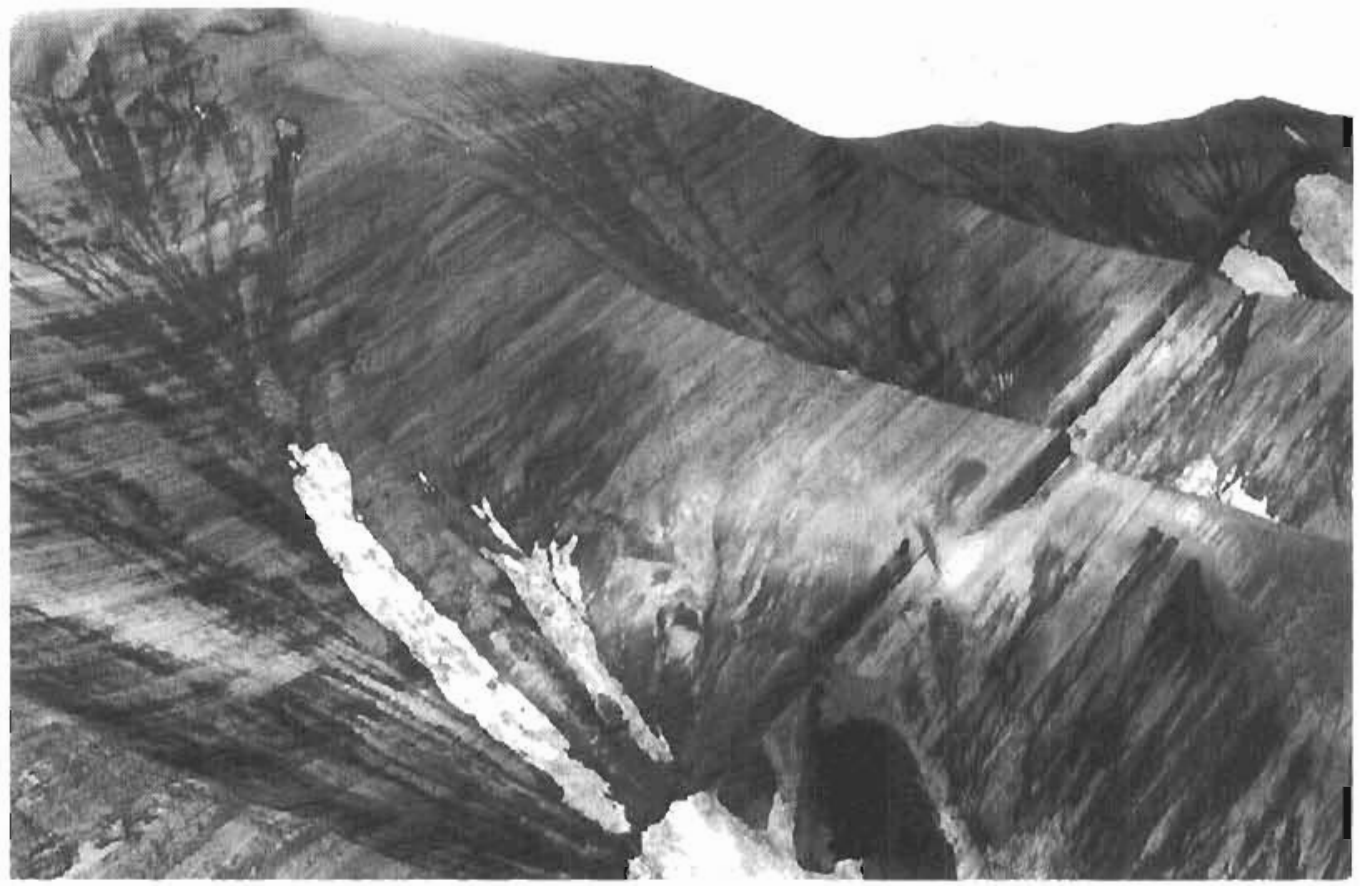

Figure 6. Upper part of the Milky River stratigraphic seclien. These Miucene strata of the Bear Lake Formation ars unconformably overlain by younger volcanics (shown in the upper leli).

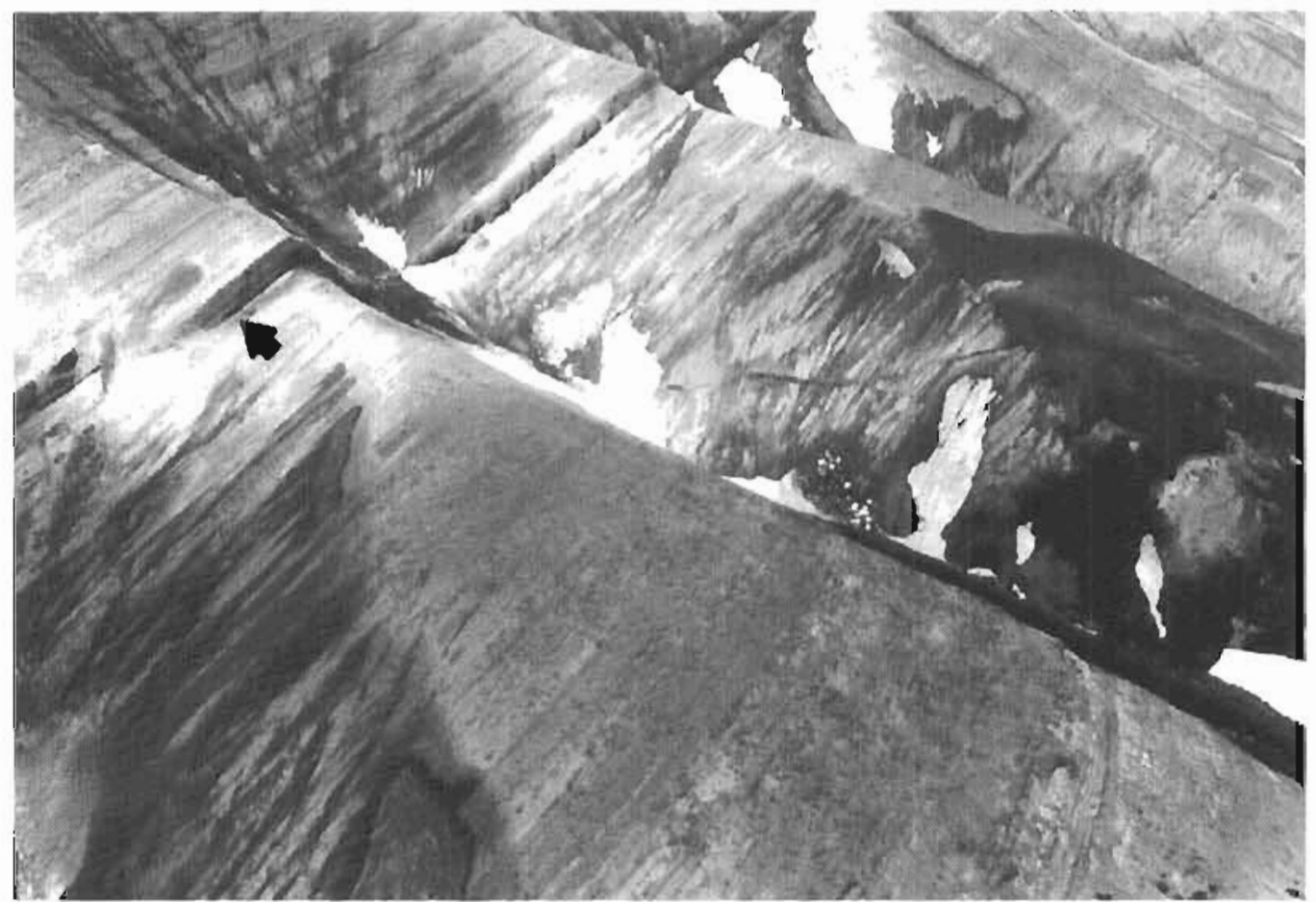

Figure 7. Lower part of the Mitky River stratigraphic section of the Bear Lake Furmation. Arrow indicates correlation marker with upper part of scclion. 


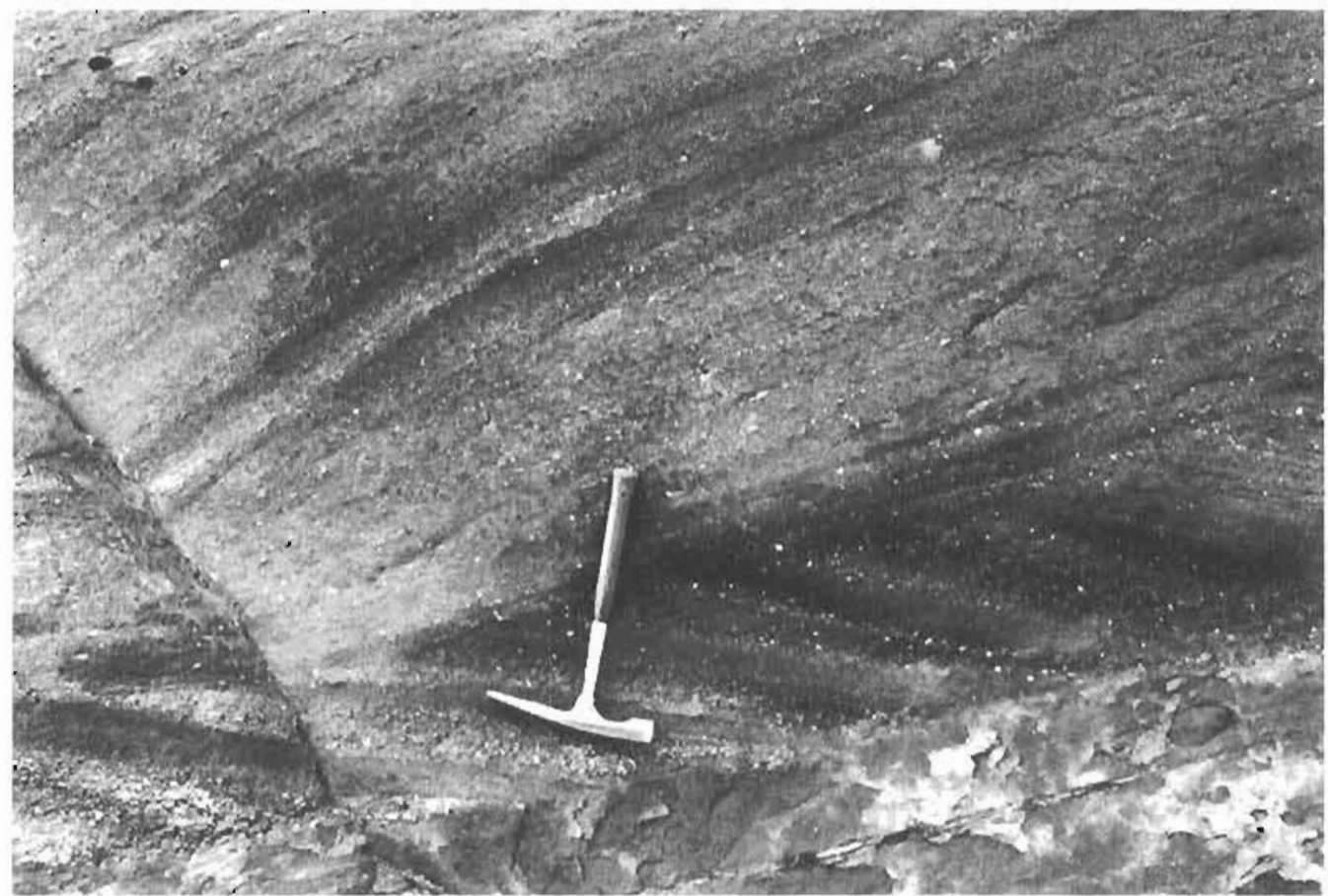

Figure 8. Crossbedded sandsione of the Bear Lake Formation common in upper part of Milky River sirdigraphic scction.

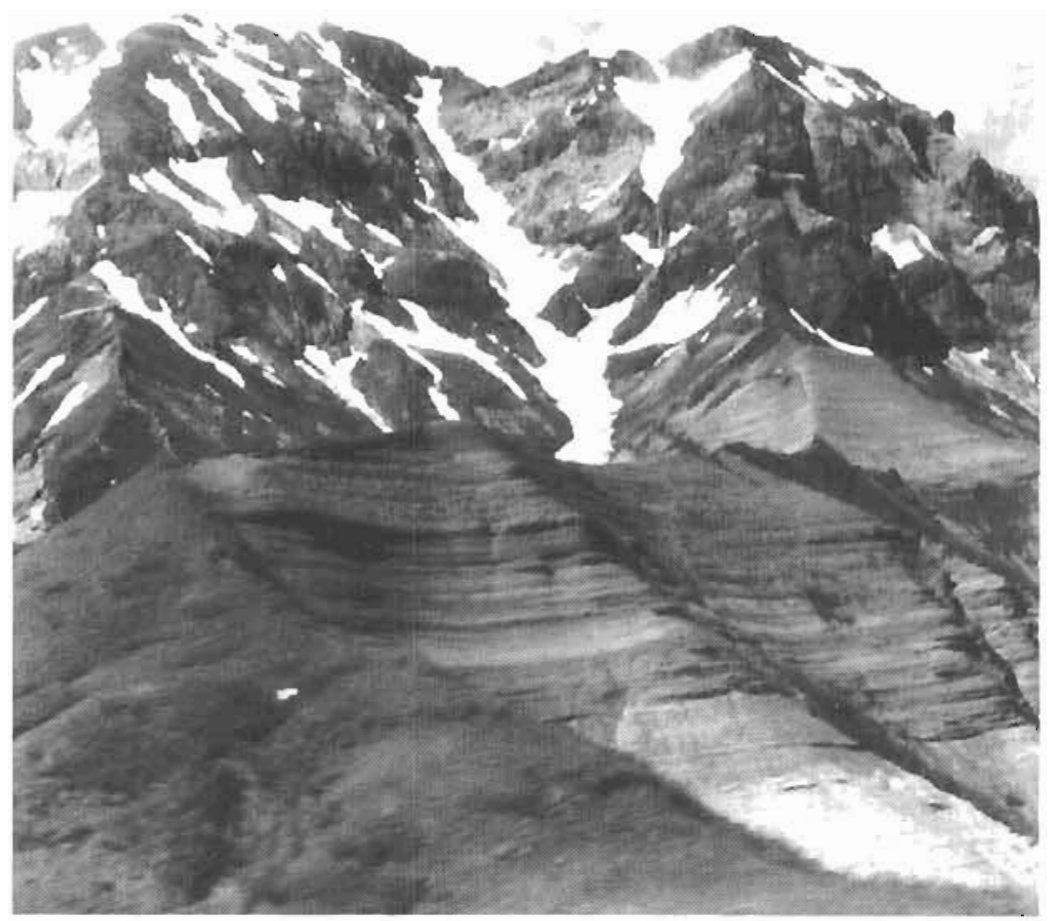

Figure 9. Southeast Bear Lake stratigraphic section. These Bear Lake Formation beds are uverlain by vol. cintics (shoswn in upoer pält of photuglaph). 


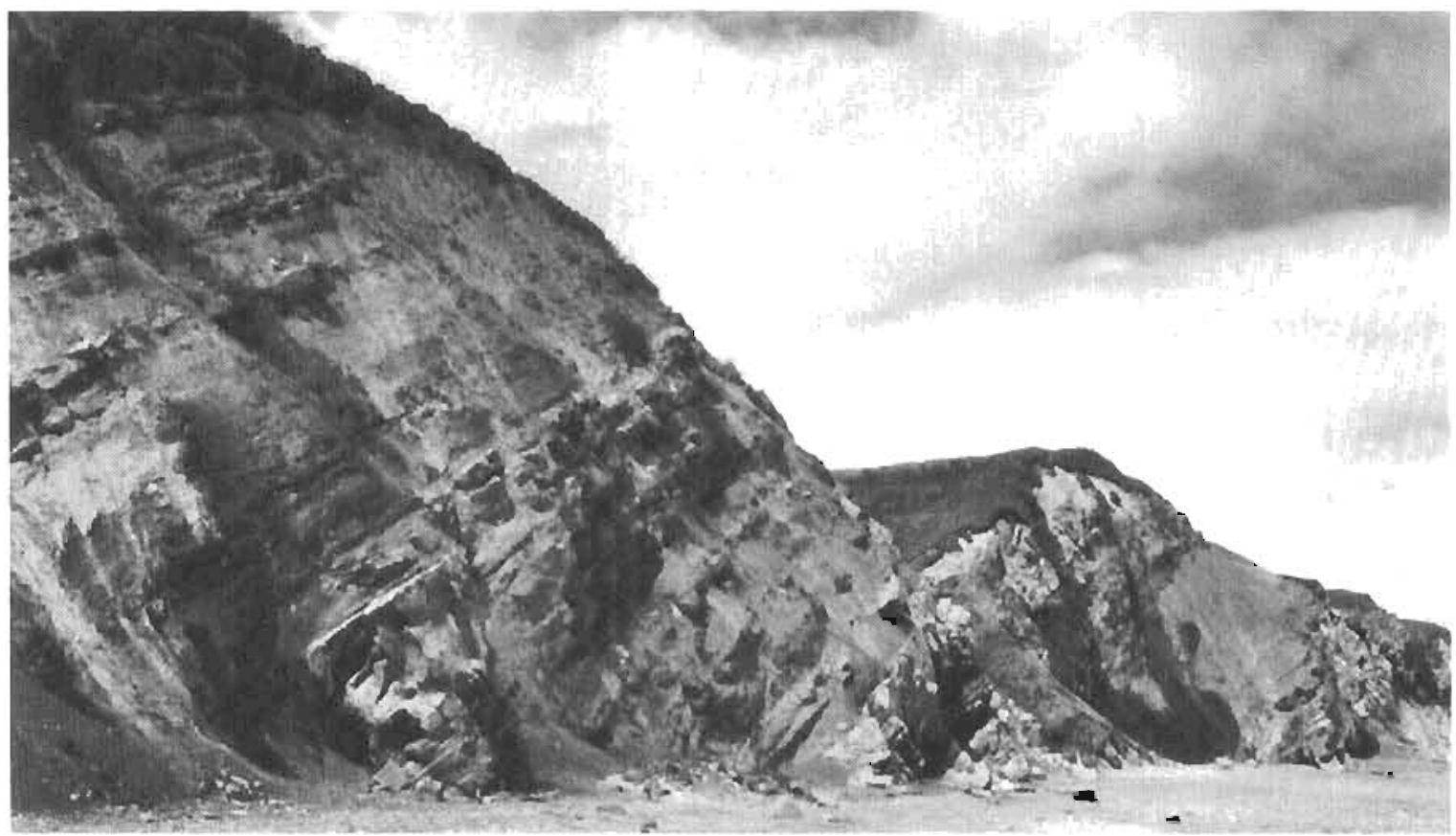

Figure 10. Heren stratigraphic sections showing bels of the Tolstoi formation (Burk, 1965) exposed along west Herendeen Bay. The sccions are separated by a fault of unknown throw.

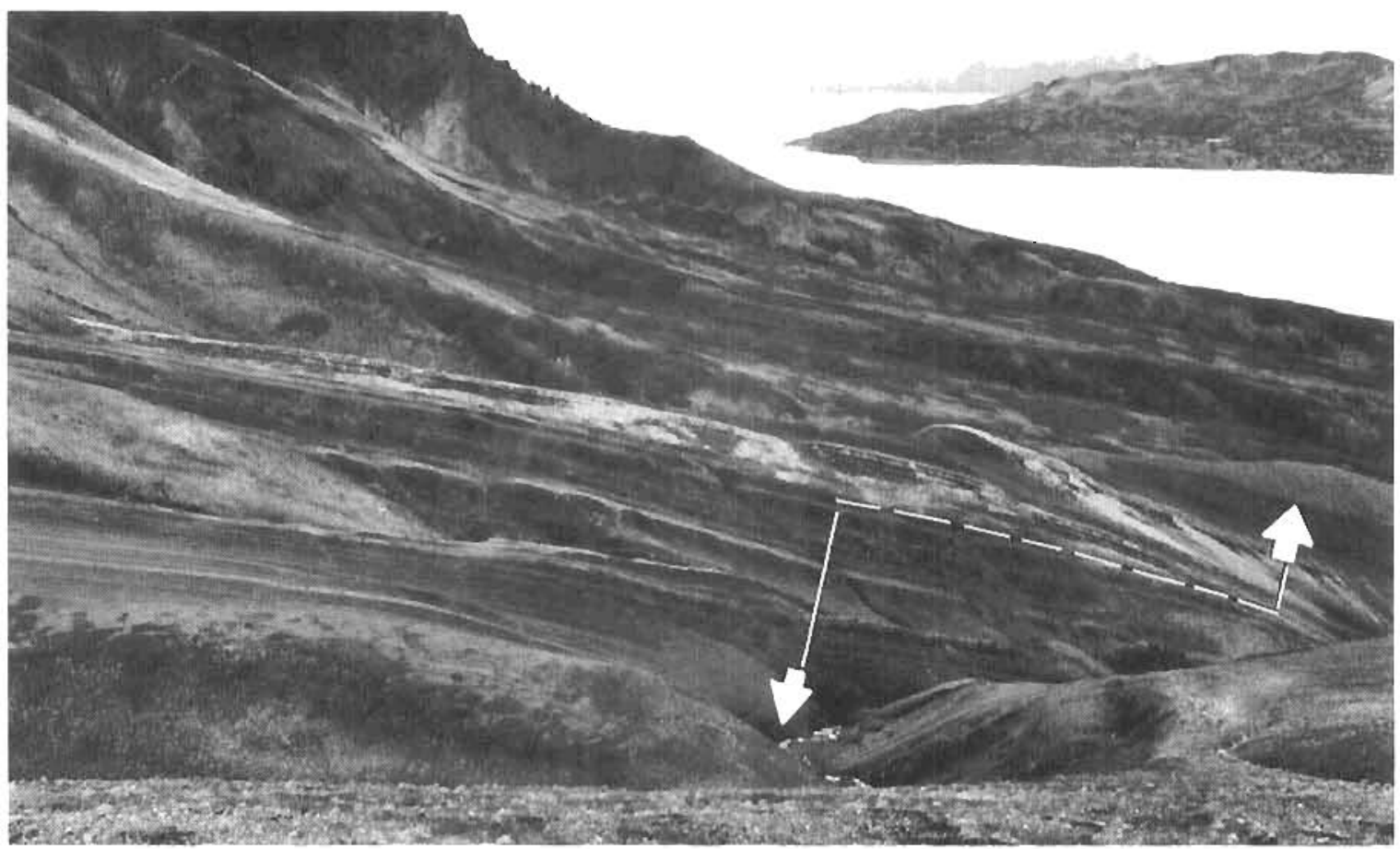

Figure I1. Upper part of Lefthand Bay-Baboa Bay stratigraphic sectian thowing heds of the Stepovak Formation (Burk, 1965). Vicw is to the south. 


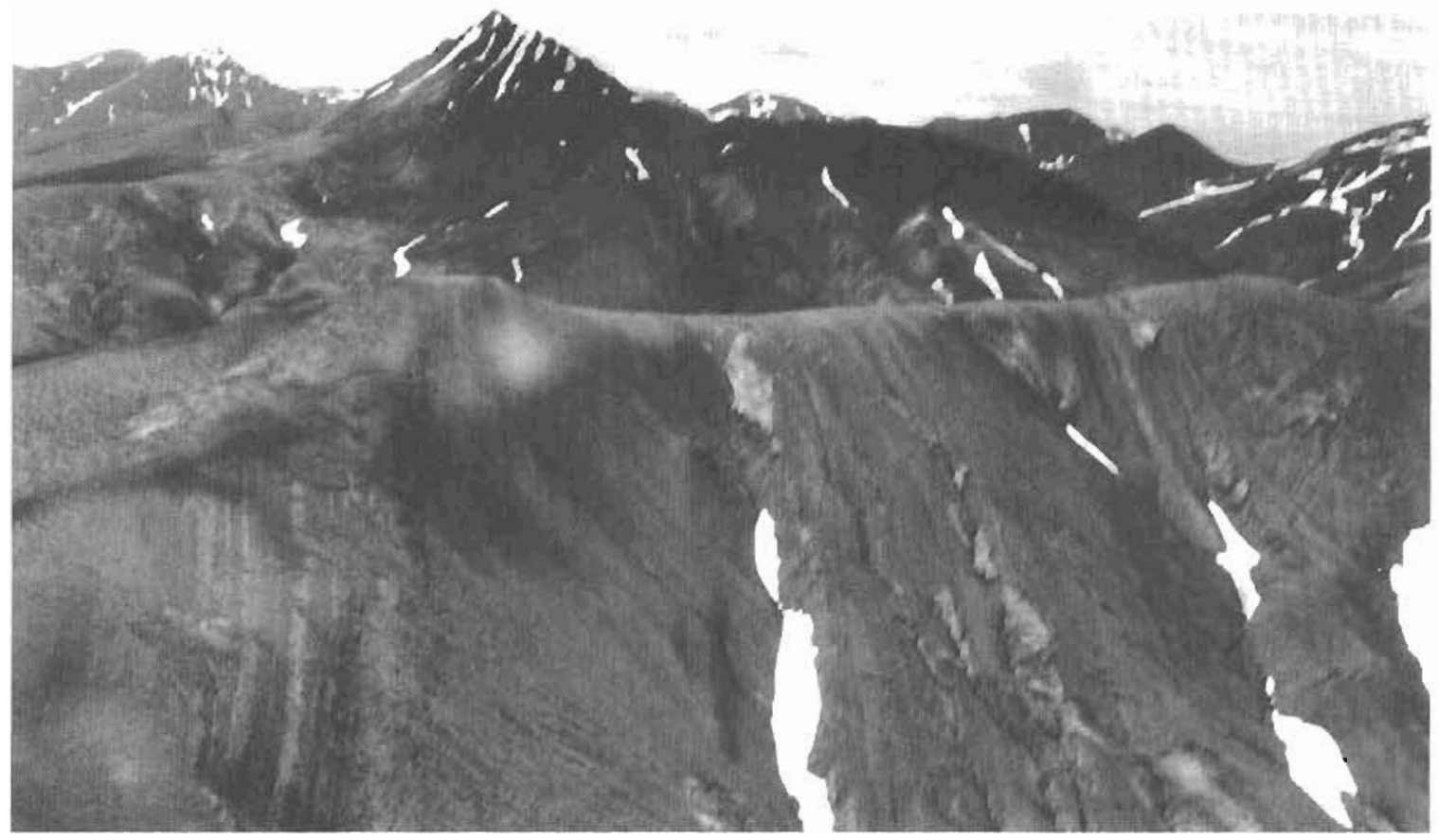

Figure 12. Beaver Bay stratigraphic scetion exposibs stralu of the Otigocene Stepovak Formation (Burk. 1965).

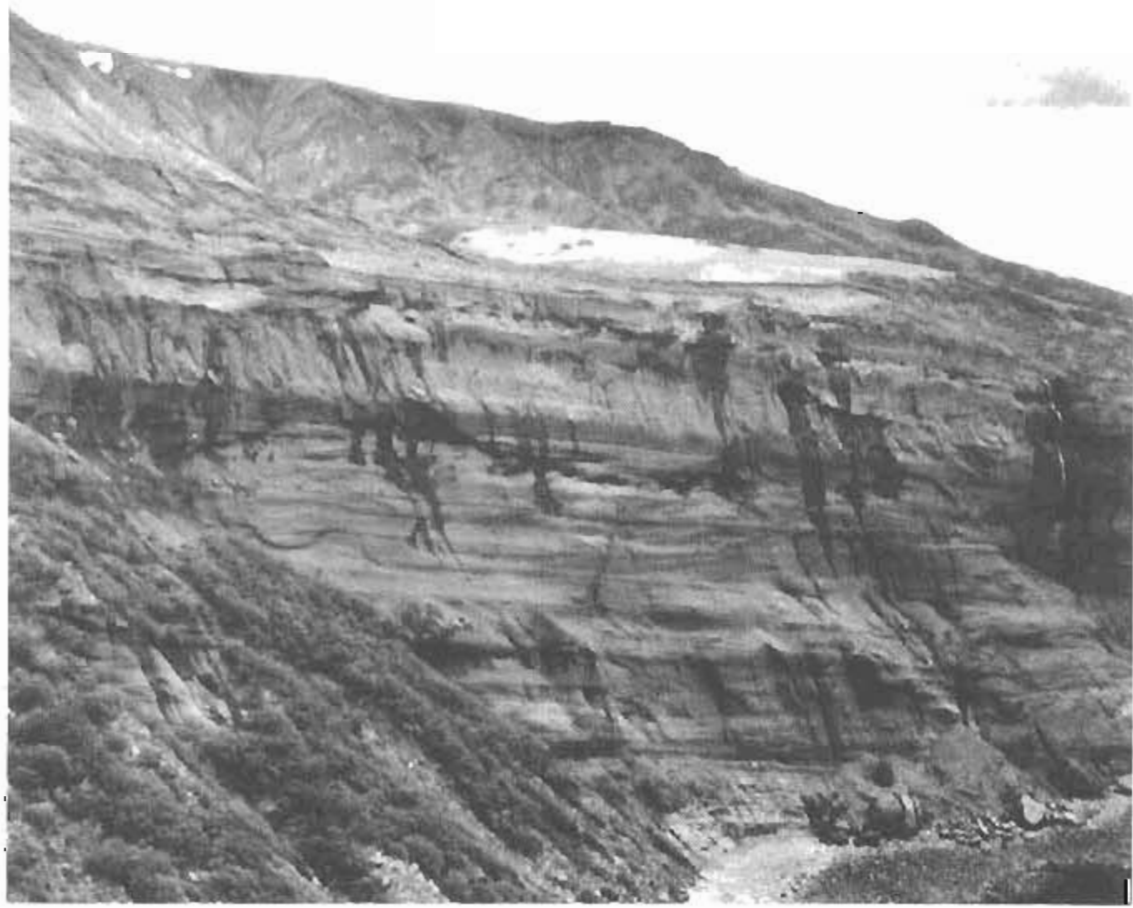

Fliaksin Peninsula stratigraphic section showing strala of the Bear Lake

Figure 13. Aliaksin Peni
Formation 


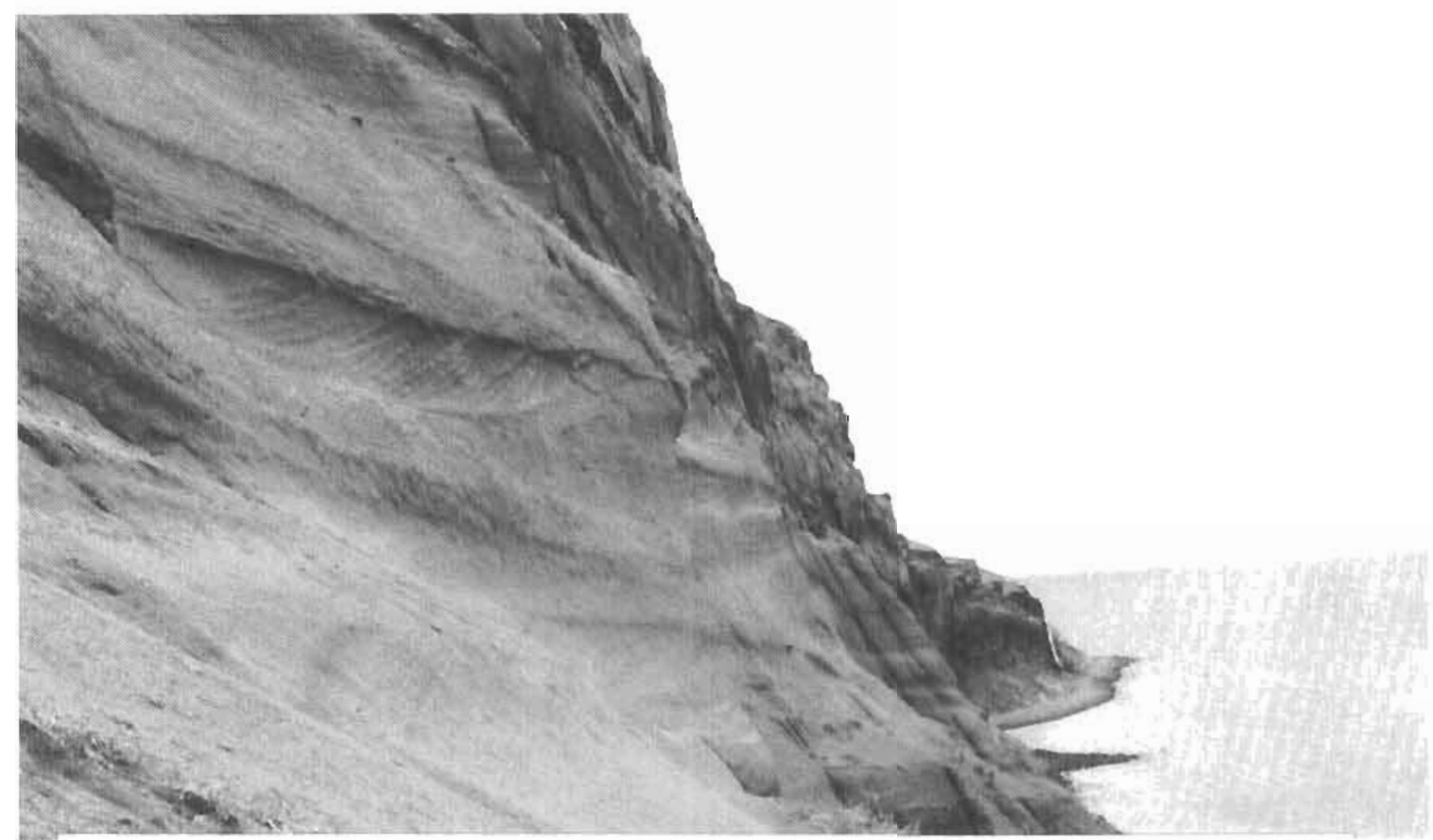

Figure 14 Massive crossbedded unit in the Bear Lake Formation. Aliaksin Peninsula stiatigraphic section View in lo the south

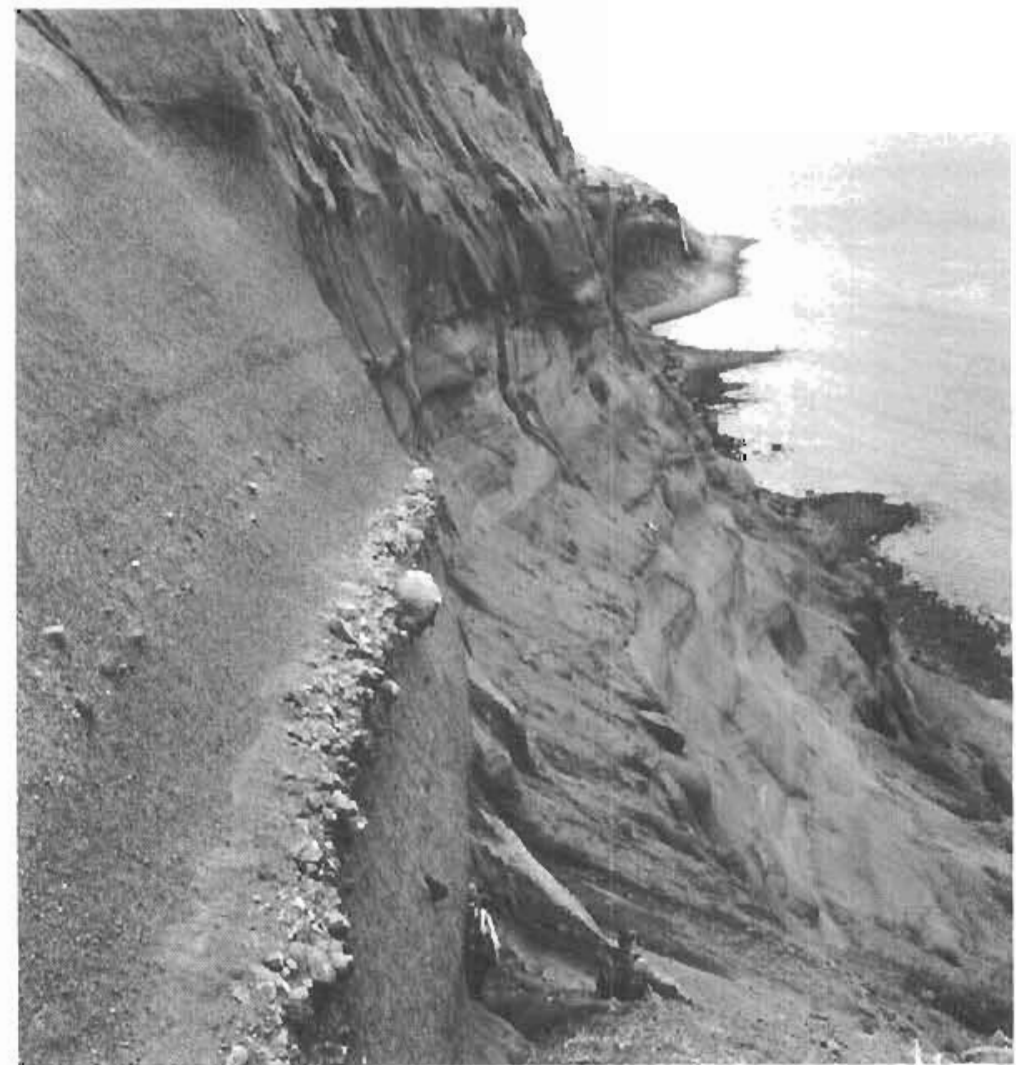

Figure 15. South-looking view of conglomerate tipping a sandstone unit of the Bear Lake Formation, Aliakssin Peninsula stratigraphic seclion. 


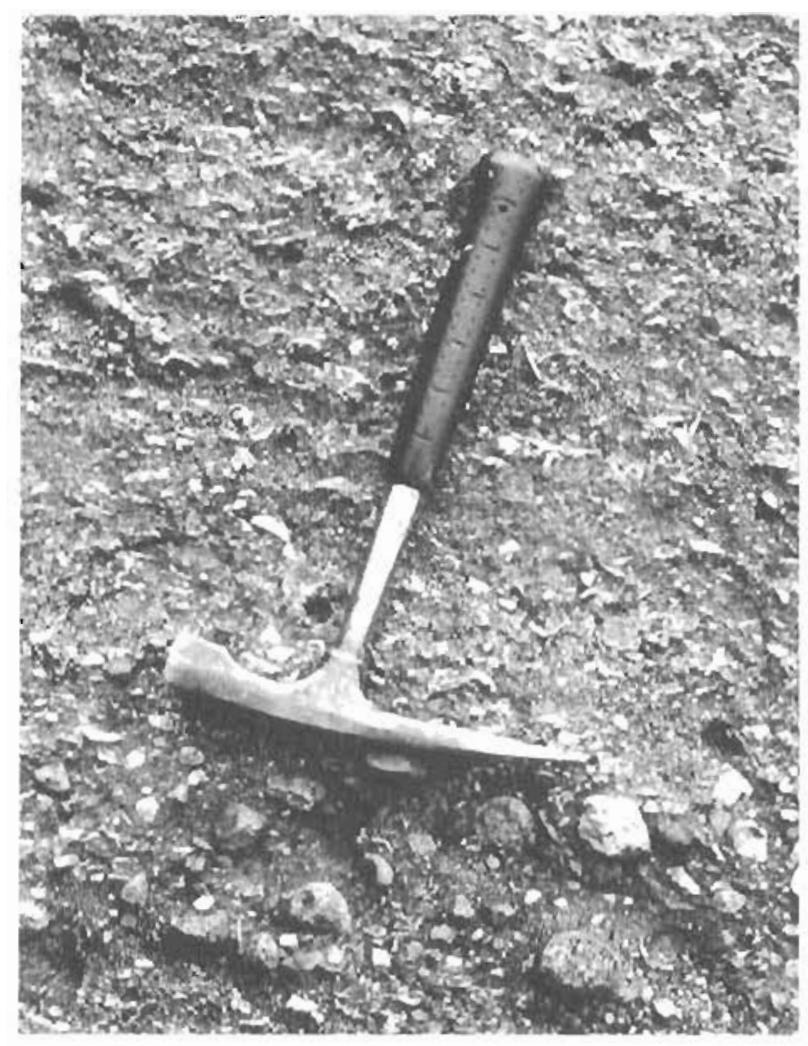

Figure 16 "Fossil-hash" sandatone unit in the Bear Lake Formation, Niaksin Peninsula stratigraphic secion

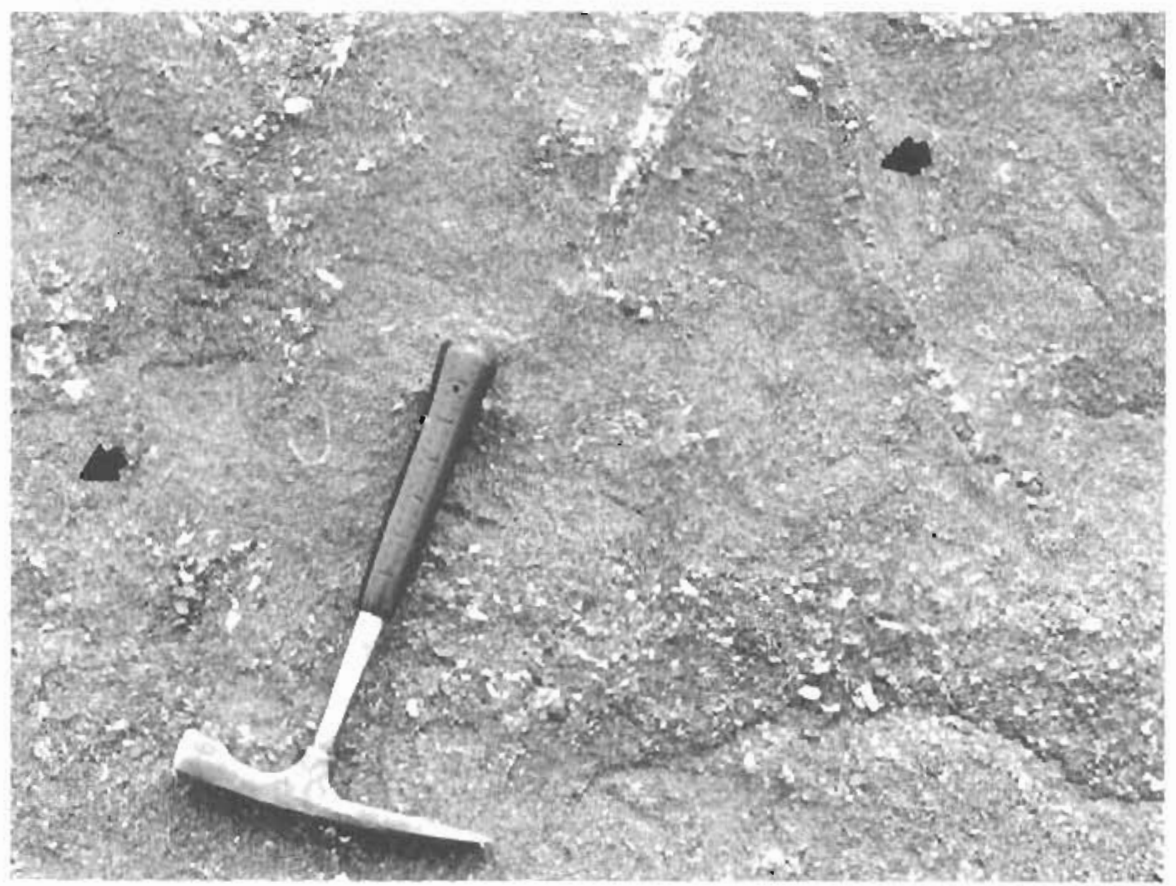

Figure 17 Burrowed uni in Bear Lake Formation. Aliaksin Peninsula stratigraphic section 


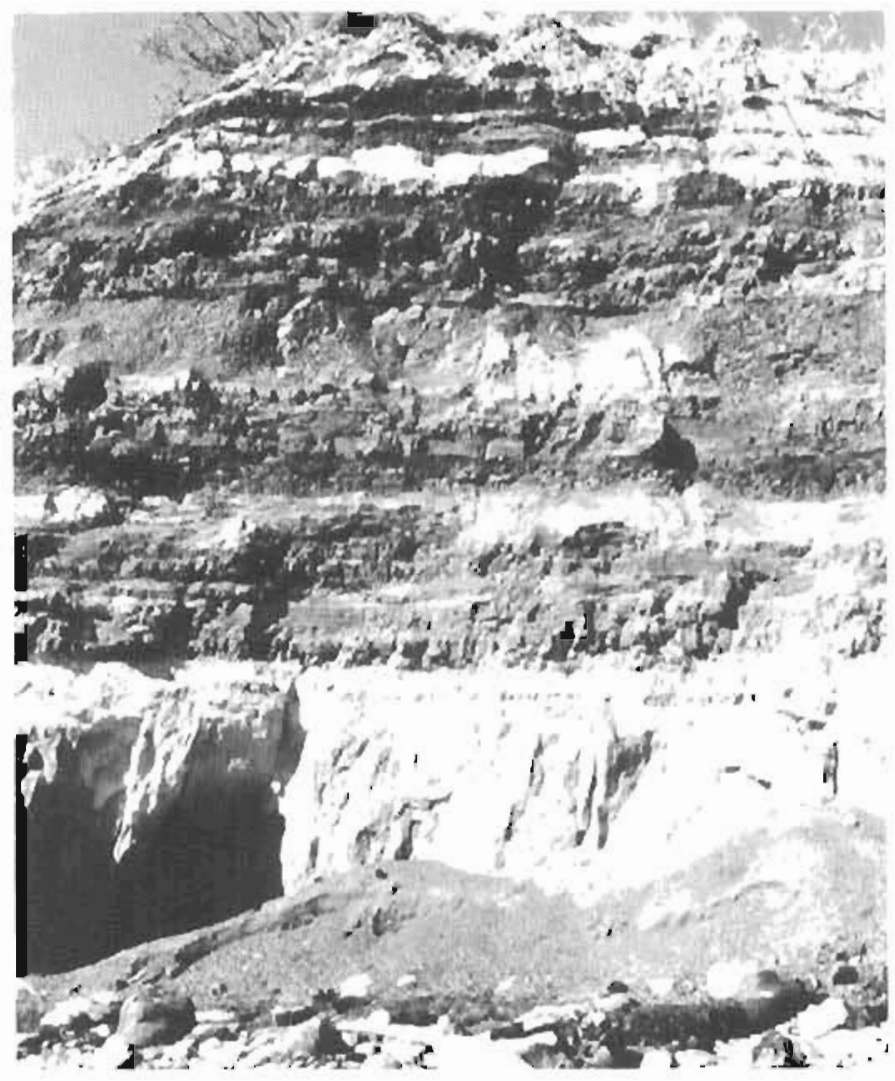

Figure 18. Lower part of the White Bluth stratigraphic section showing Bar Lake Formation strata, Unga Island.

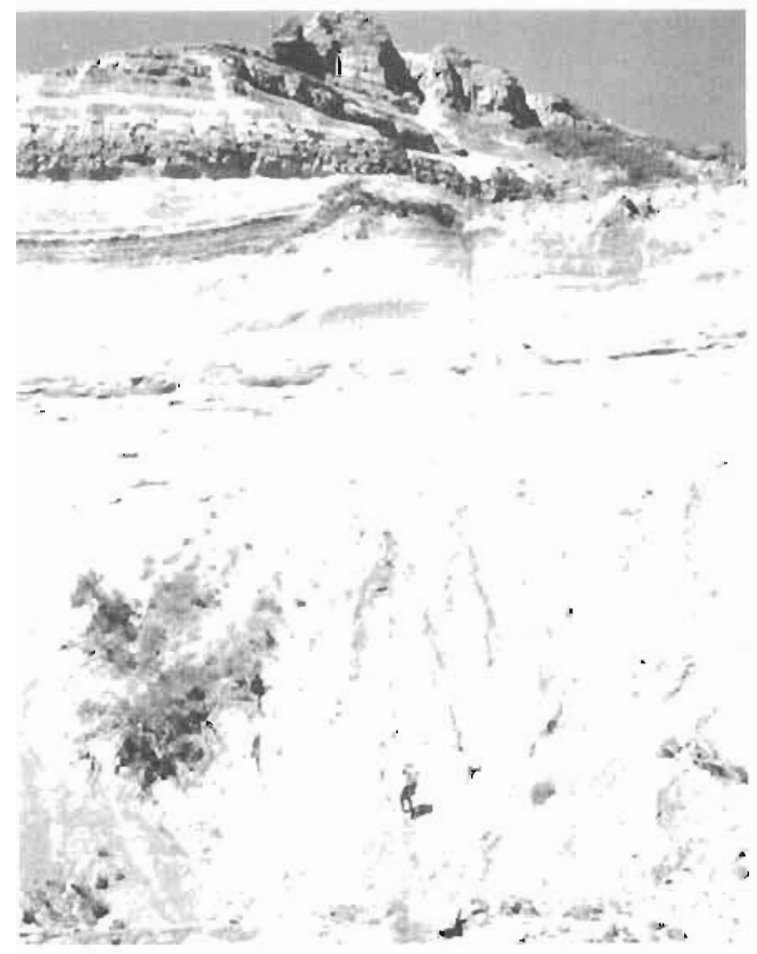

Figure 19. Middle parl of the White Bluff -iraliglathic section, showing Bear Lake Formation strata. Ungu Island. 


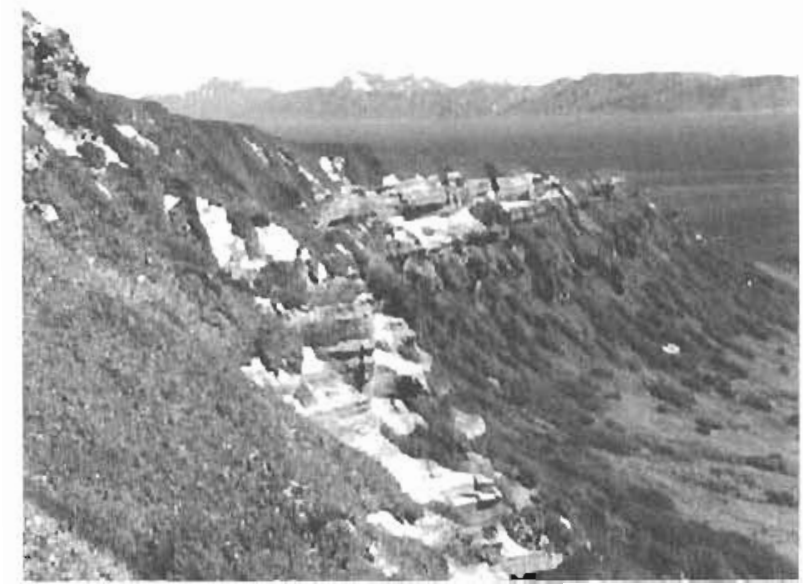

Figure 20. Upper part of the Whire Bluff stratigraphic section showing Bear Lake Formation strala, Unga Island. Viow is 10 the north.

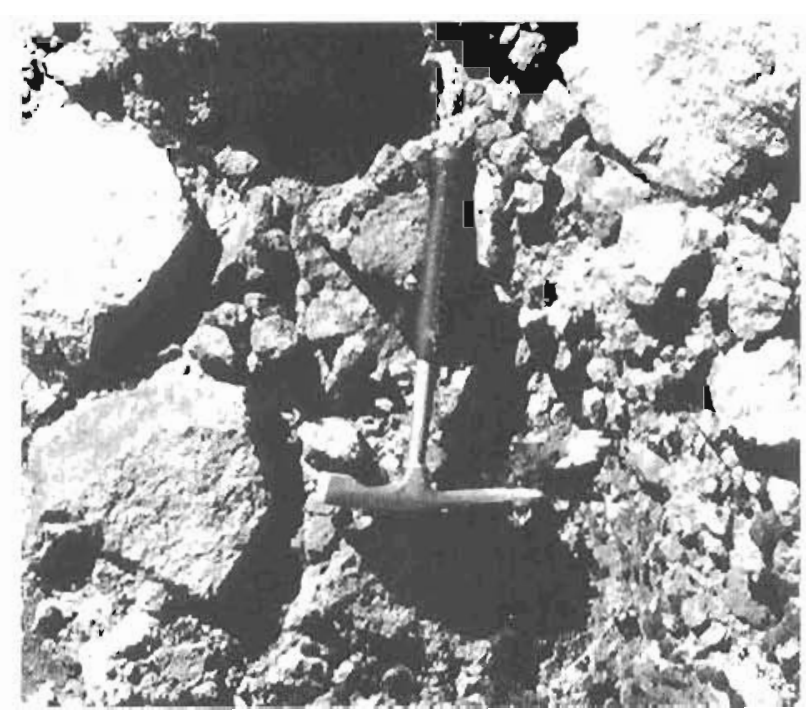

Figure 21. Agglomerale unit in the Bear Lake Formation capping the White Blulf straligraphic section.

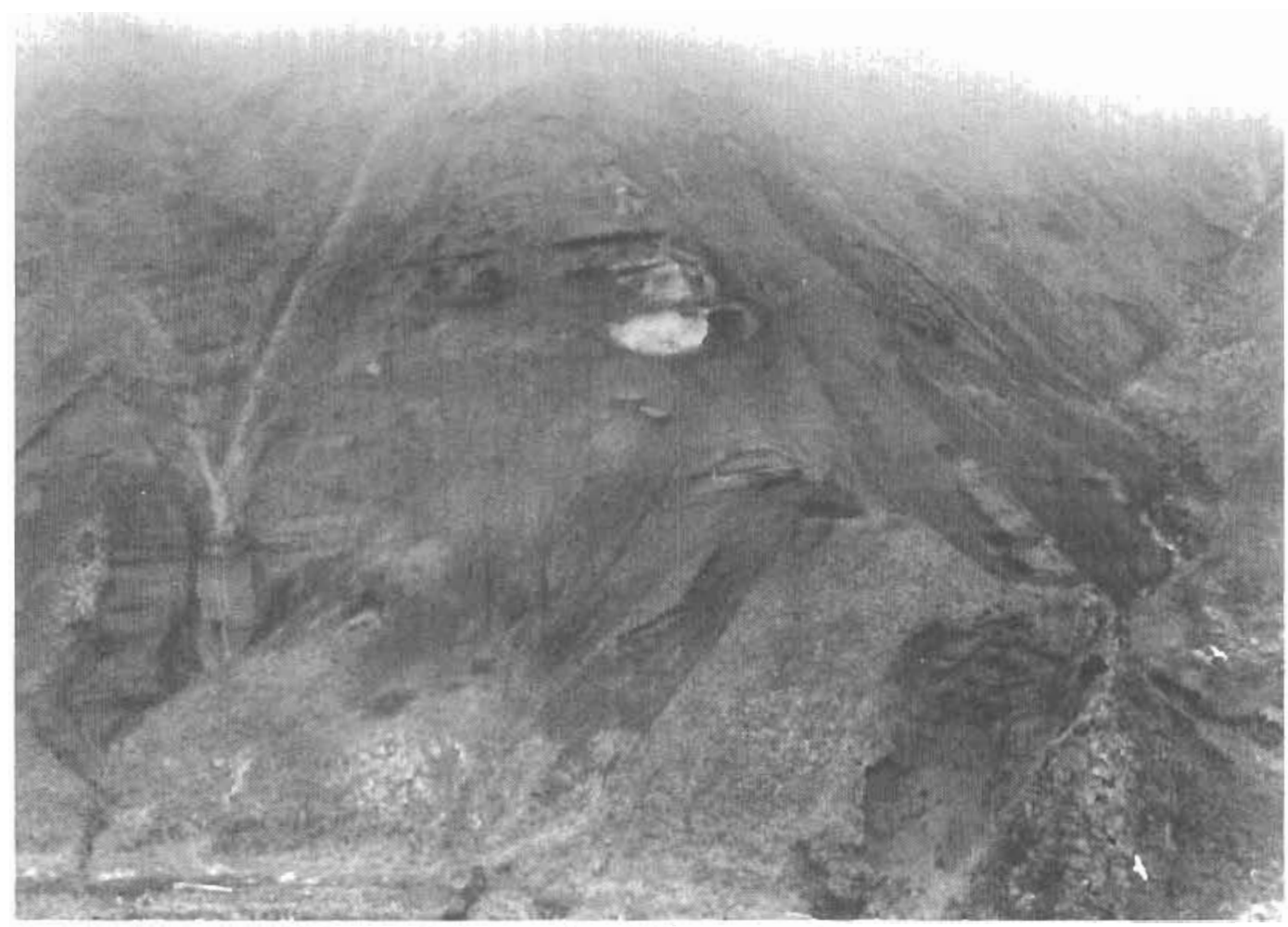

Figure 22. East Morzhovoi Bay stratiglaphic sectuson showing the Tachilni Formation. This lormation is exposed in several places atong the bay. 


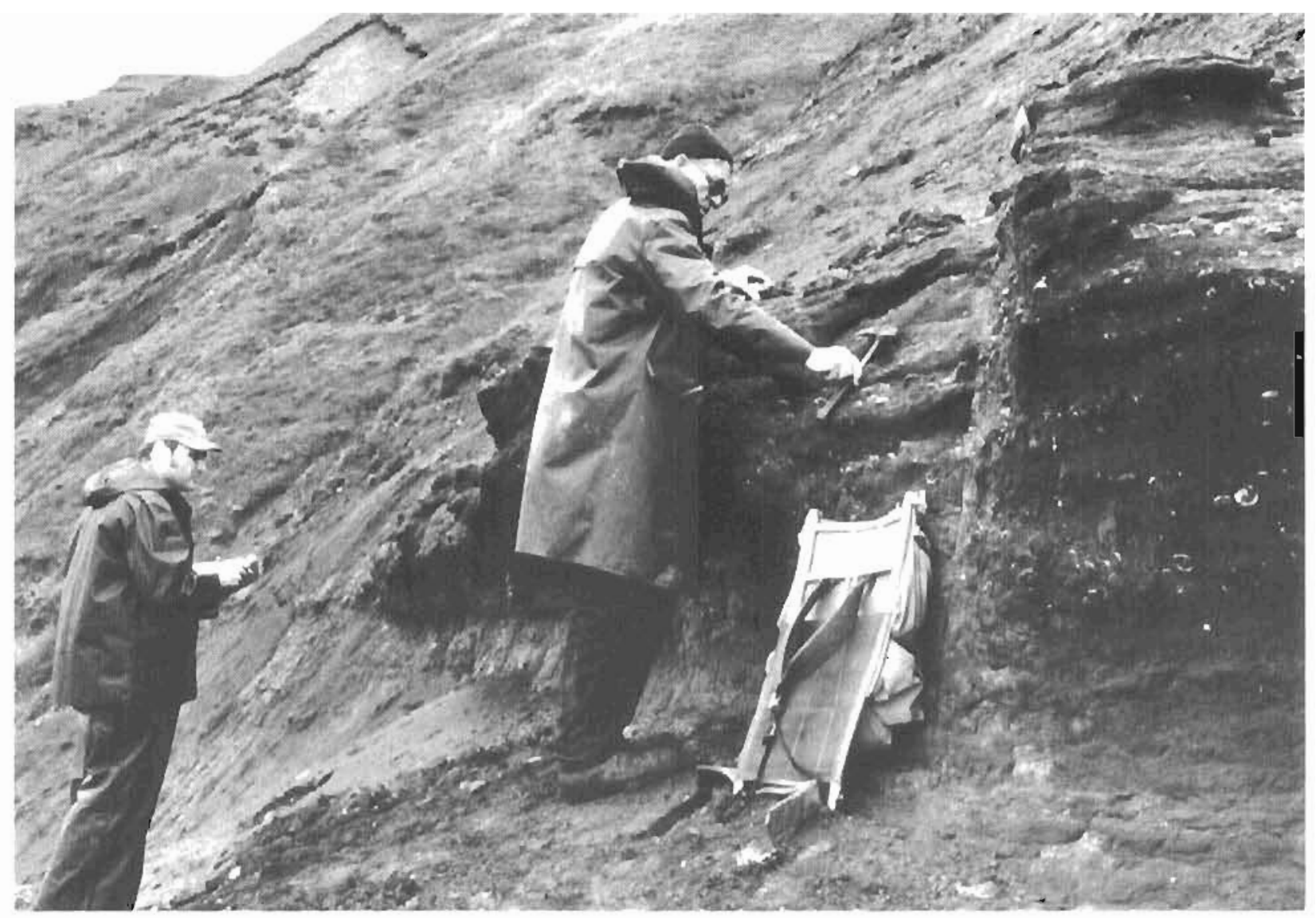

Figure 23. Authors Bolm (left) and Lyle working on a fossiliferous ledec in the Tachilni Formation, East Morzhovoi Bay section.

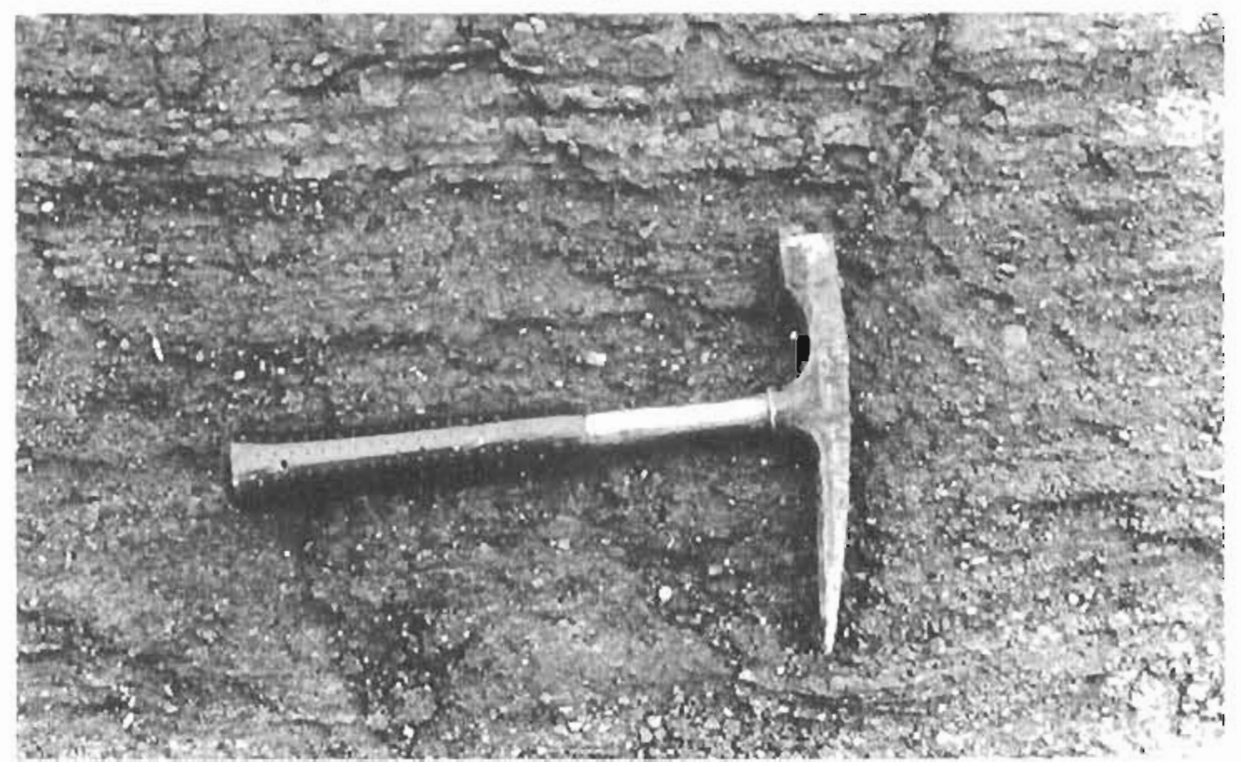

Figurc 24. Shats: rip-up laycrs in the Tachilni Formation, East Mor hhovoi Bay' stratigraphic secion. 